Prepared in cooperation with the South Dakota Department of Transportation

\title{
Peak-Flow Frequency Estimates Based on Data through Water Year 2001 for Selected Streamflow-Gaging Stations in South Dakota
}
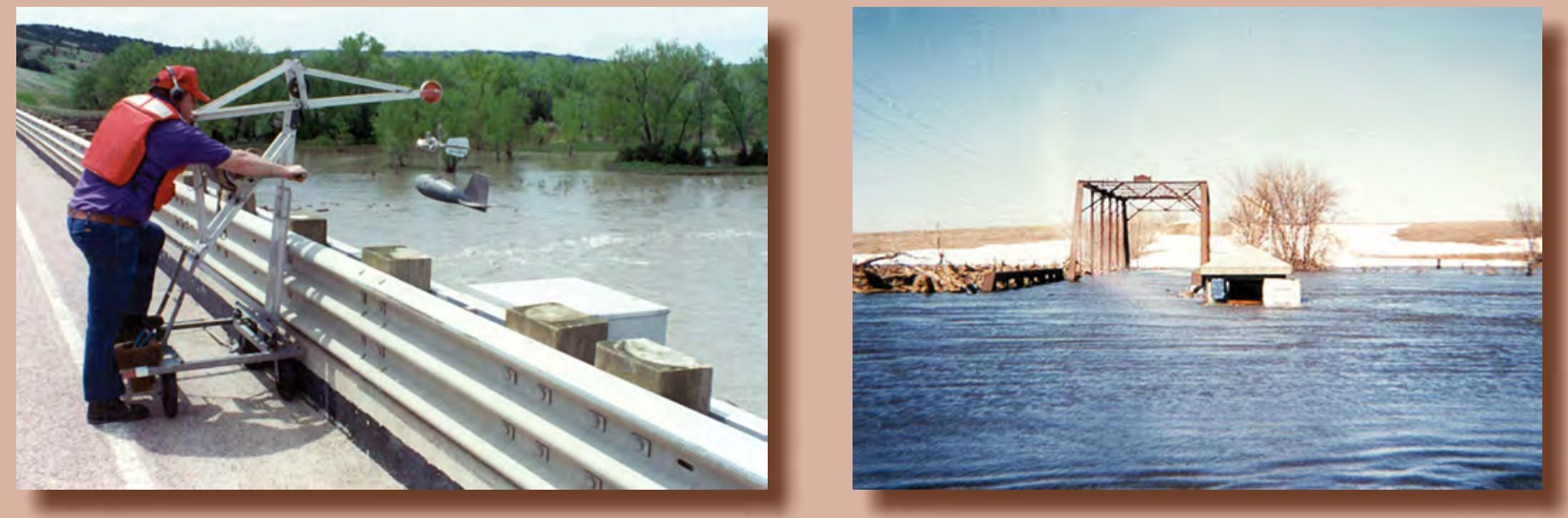

Scientific Investigations Report 2008-5104

U.S. Department of the Interior

U.S. Geological Survey 
Cover photographs: Upper left: U.S. Geological Survey hydrologic technician measures the flow of the Cheyenne River near Plainview (station 06438500) during flood conditions in 1997. Photograph by U.S. Geological Survey.

Upper right: James River near Redfield (station 06475000) during flood conditions in 1997. Photograph by U.S. Geological Survey.

Bottom: Cars were stacked by the force of water as it pushed through Rapid City leaving the banks of Rapid Creek during the 1972 flood. Photograph courtesy of the Rapid City Journal. 


\section{Peak-Flow Frequency Estimates Based on Data through Water Year 2001 for Selected Streamflow-Gaging Stations in South Dakota}

By Steven K. Sando, Daniel G. Driscoll, and Charles Parrett

Prepared in cooperation with the South Dakota Department of Transportation

Scientific Investigations Report 2008-5104 


\section{U.S. Department of the Interior DIRK KEMPTHORNE, Secretary}

\section{U.S. Geological Survey \\ Mark D. Myers, Director}

\section{U.S. Geological Survey, Reston, Virginia: 2008}

For product and ordering information:

World Wide Web: http://www.usgs.gov/pubprod

Telephone: 1-888-ASK-USGS

For more information on the USGS — the Federal source for science about the Earth, its natural and living resources, natural hazards, and the environment:

World Wide Web: http://www.usgs.gov

Telephone: 1-888-ASK-USGS

Any use of trade, product, or firm names is for descriptive purposes only and does not imply endorsement by the U.S. Government.

Although this report is in the public domain, permission must be secured from the individual copyright owners to reproduce any copyrighted materials contained within this report.

Suggested citation:

Sando, S.K., Driscoll, D.G., and Parrett, Charles, 2008, Peak-flow frequency estimates based on data through water year 2001 for selected streamflow-gaging stations in South Dakota: U.S. Geological Survey Scientific Investigations Report 2008-5104, 367 p. 


\section{Contents}

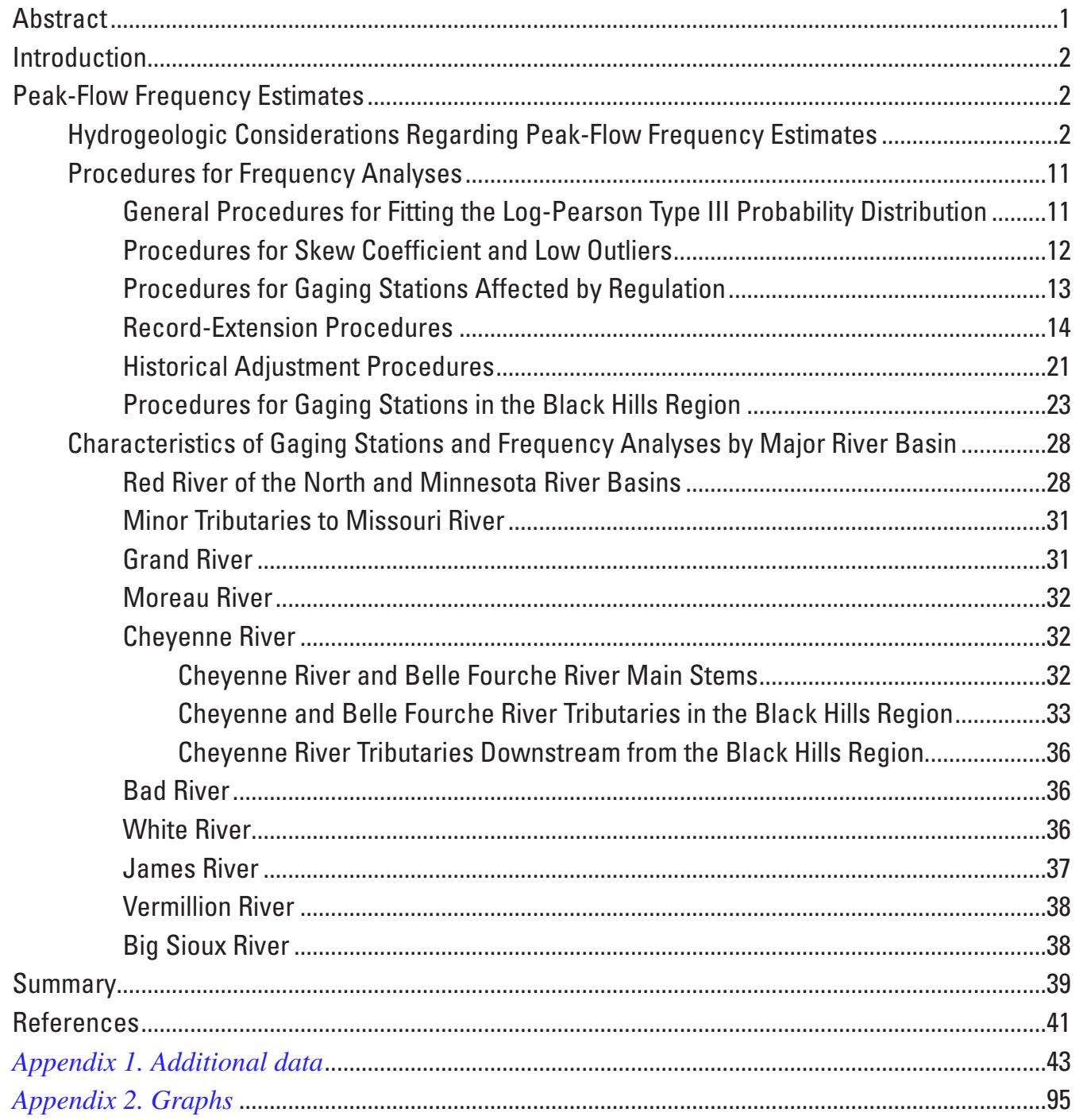

\section{Figures}

1-2. Maps showing:

1. Locations of selected streamflow-gaging stations in South Dakota ..........................3

2. Main physiographic divisions of South Dakota .....................................................

3-4. Graphs showing:

3. Relations among annual precipitation and peak-flow characteristics for short- and long-term periods for selected sites in eastern South Dakota.

4. Peak-flow frequency information for three long-term stations in eastern South Dakota based on data for three different time periods. 
5-6. Maps showing:

5. Generalized surficial geology of South Dakota

6. Hydrogeologic settings for the Black Hills region

7-11. Graphs showing:

7. Peak-flow frequency information for Firesteel Creek near Mount Vernon (06477500) illustrating effects of low-outlier and skew adjustments on frequency curve fits

8. Peak-flow frequency information for normalized high-outlier peak flows of the Black Hills regional mixed-population analysis

9. Peak-flow frequency information for $(A)$ Battle Creek near Keystone (06404000) and (B) Grace Coolidge Creek near Game Lodge near Custer (06404998) illustrating application of the Black Hills regional mixedpopulation analysis.

10. Peak-flow frequency information illustrating influences of the loss-zone hydrogeologic setting

11.1-11.272 Appendix 2. Graphs showing peak-flow information for stations:

$11.1 \quad$ 05050000, Bois de Sioux River near White Rock, SD .............................................96

11.2 05051650, La Belle Creek near Veblen, SD ..........................................................97

11.3 05289950, Little Minnesota River tributary at Sisseton, SD .................................98

11.4 05289985, Big Coulee Creek near Peever, SD ..................................................99

11.5 05290000, Little Minnesota River near Peever, SD ............................................100

11.6 05290300, North Fork Whetstone River tributary near Wilmot, SD .......................101

11.7 05291000, Whetstone River near Big Stone City, SD ...........................................102

11.8 05292000, Minnesota River at Ortonville, MN ……..............................................103

11.9 05292600, North Fork Yellow Bank River tributary near Stockholm, SD ..............104

11.10 05292704, North Fork Yellow Bank River near Odessa, MN...............................105

11.11 05299700, Cobb Creek near Gary, SD ..................................................................106

11.12 06334500, Little Missouri River at Camp Crook, SD .............................................107

11.13 06354845, Spring Creek tributary near Greenway, SD ........................................108

11.14 06354860, Spring Creek near Herreid, SD ........................................................109

11.15 06354882, Oak Creek near Wakpala, SD .........................................................110

11.16 06355400, North Fork Grand River tributary near Lodgepole, SD ......................111

11.17 06355500, North Fork Grand River near White Butte, SD ..................................112

11.18 06356000, South Fork Grand River at Buffalo, SD ............................................113

11.19 06356150, North Jack Creek near Ludlow, SD ...............................................114

$11.20 \quad$ 06356500, South Fork Grand River near Cash, SD ..........................................115

11.21 06356600, South Fork Grand River tributary near Bison, SD .............................116

11.22 06357500, Grand River at Shadehill, SD.......................................................117

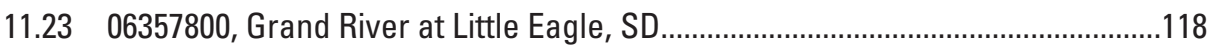

11.24 06358520, Deadman Creek tributary near Mobridge, SD ..................................119

11.25 06358540, Blue Blanket Creek tributary near Glenham, SD .............................120

11.26 06358550, Battle Creek tributary near Castle Rock, SD ......................................121

11.27 06358600, South Fork Moreau River tributary near Redig, SD ...........................122

11.28 06358620, Sand Creek tributary near Redig, SD ...........................................123

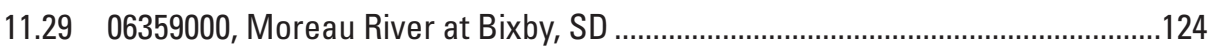

11.30 06359300, Deep Creek tributary near Maurine, SD .........................................125

$11.31 \quad 06359500$, Moreau River near Faith, SD .............................................................126 
11.32 06359700, Thunder Butte Creek tributary near Meadow, SD .............................127

11.33 06359850, Elm Creek tributary near Dupree, SD ..............................................128

11.34 06360000, Moreau River near Eagle Butte, SD................................................129

11.35 06360350, Little Moreau River tributary near Firesteel, SD .................................130

11.36 06360500, Moreau River near Whitehorse, SD …….........................................131

11.37 06361020, Swan Lake tributary near Bowdle, SD ............................................132

11.38 06392900, Beaver Creek at Mallo Camp near Four Corners, WY ........................133

11.39 06392950, Stockade Beaver Creek near Newcastle, WY....................................134

$11.40 \quad 06395000$, Cheyenne River at Edgemont, SD ...............................................135

11.41 06396200, Fiddle Creek near Edgemont, SD...................................................136

11.42 06396300, Cottonwood Creek tributary near Edgemont, SD ..............................137

11.43 06396350, Red Canyon Creek tributary near Pringle, SD .....................................138

11.44 06399300, Hat Creek tributary near Ardmore, SD ...............................................139

11.45 06399700, Piney Creek near Ardmore, SD ...................................................140

11.46 06400000, Hat Creek near Edgemont, SD .........................................................141

11.47 06400497, Cascade Springs near Hot Springs, SD ............................................142

$11.48 \quad 06400500$, Cheyenne River near Hot Springs, SD..............................................143

11.49 06400875, Horsehead Creek at Oelrichs, SD ....................................................144

11.50 06400900, Horeshead Creek tributary near Smithwick, SD .................................145

11.51 06401500, Cheyenne River below Angostura Dam, SD ........................................146

$11.52 \quad 06402000$, Fall River at Hot Springs, SD ....................................................

$11.53 \quad 06402100$, Fall River tributary at Hot Springs, SD ............................................148

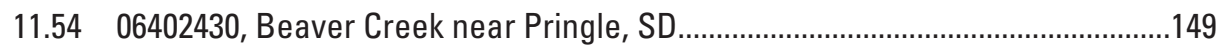

11.55 06402500, Beaver Creek near Buffalo Gap, SD .............................................150

11.56 06402995, French Creek above Stockade Lake near Custer, SD ........................151

11.57 06403300, French Creek above Fairburn, SD ..................................................152

11.58 06403800, Battle Creek tributary near Keystone, SD ........................................153

11.59 06404000, Battle Creek near Keystone, SD ....................................................154

11.60 06404800, Grace Coolidge Creek near Hayward, SD ........................................155

11.61 06404998, Grace Coolidge Creek near Game Lodge near Custer, SD ................156

11.62 06405800, Bear Gulch near Hayward, SD ...................................................157

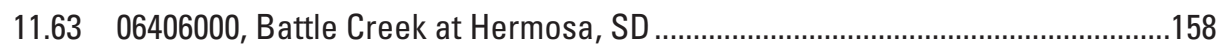

$11.64 \quad 06406100$, Battle Creek tributary near Hermosa, SD ..........................................159

11.65 06406500, Battle Creek below Hermosa, SD .....................................................160

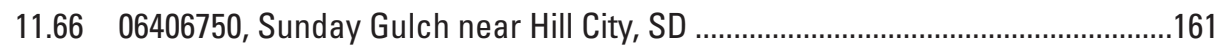

11.67 06406800, Newton Fork near Hill City, SD ......................................................162

11.68 06406900, Palmer Creek near Hill City, SD ......................................................163

11.69 06406920, Spring Creek above Sheridan Lake near Keystone, SD ......................164

11.70 06407500, Spring Creek near Keystone, SD ....................................................165

11.71 06408500, Spring Creek near Hermosa, SD .....................................................166

11.72 06408700, Rhoads Fork near Rochford, SD ....................................................167

11.73 06408850, Silver Creek near Rochford, SD......................................................168

11.74 06408900, Heeley Creek near Hill City, SD .....................................................169

11.75 06409000, Castle Creek above Deerfield Reservoir near Hill City, SD .................170

11.76 06410000, Castle Creek below Deerfield Dam, SD............................................171

11.77 06410500, Rapid Creek above Pactola Reservoir at Silver City, SD ....................172 
11.78 06411500, Rapid Creek below Pactola Dam, SD ..............................................173

11.79 06412500, Rapid Creek above Canyon Lake near Rapid City, SD ........................174

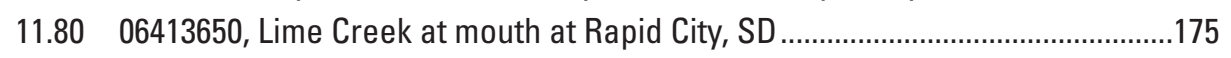

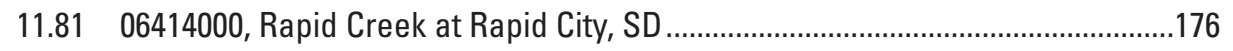

11.82 06421500, Rapid Creek near Farmingdale, SD .....................................................177

11.83 06421750, Rapid Creek tributary near Farmingdale, SD ....................................178

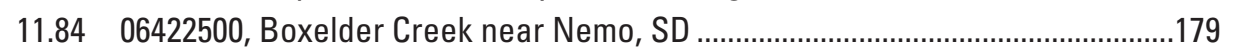

11.85 06423010, Boxelder Creek near Rapid City, SD ..............................................180

11.86 06423500, Cheyenne River near Wasta, SD ....................................................181

11.87 06424000, Elk Creek near Roubaix, SD ............................................................

11.88 06425100, Elk Creek near Rapid City, SD ...........................................................183

11.89 06425500, Elk Creek near Elm Springs, SD ...................................................184

11.90 06428500, Belle Fourche River at Wyoming-South Dakota State line .................185

11.91 06429500, Cold Springs Creek at Buckhorn, WY .................................................186

11.92 06429905, Sand Creek near Ranch A near Beulah, WY......................................187

11.93 06430500, Redwater Creek at Wyoming-South Dakota State line .......................188

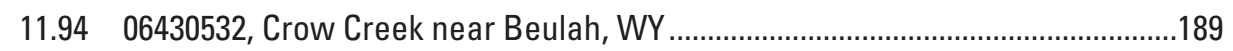

11.95 06430770, Spearfish Creek near Lead, SD ......................................................190

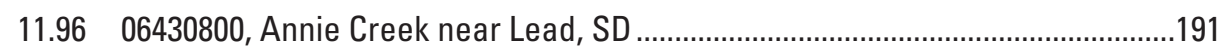

11.97 06430850, Little Spearfish Creek near Lead, SD..............................................192

11.98 06430898, Cleopatra Creek near Spearfish, SD .................................................193

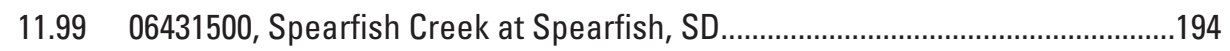

$11.100 \quad 06432200$, Polo Creek near Whitewood, SD.......................................................195

11.101 06432230, Miller Creek near Whitewood, SD ................................................196

$11.102 \quad 06433000$, Redwater River above Belle Fourche, SD .........................................197

11.103 06433500, Hay Creek at Belle Fourche, SD ..................................................198

11.104 06434800, Owl Creek tributary near Belle Fourche, SD ..................................199

$11.105 \quad 06436000$, Belle Fourche River near Fruitdale, SD .........................................200

11.106 06436156, Whitetail Creek at Lead, SD .............................................................201

11.107 06436180, Whitewood Creek above Whitewood, SD ........................................202

11.108 06436190, Whitewood Creek near Whitewood, SD ............................................203

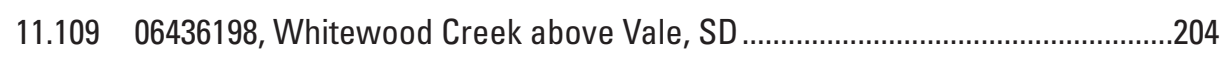

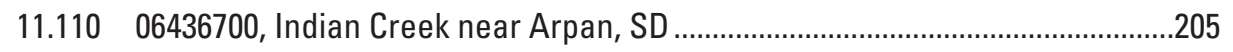

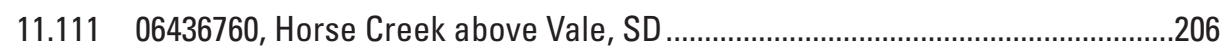

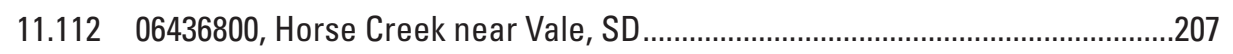

11.11306437000 , Belle Fourche River near Sturgis, SD ............................................208

11.114 06437020, Bear Butte Creek near Deadwood, SD .............................................209

11.115 06437100, Boulder Creek near Deadwood, SD ...................................................210

11.116 06437500, Bear Butte Creek near Sturgis, SD ...............................................211

$11.117 \quad 06438000$, Belle Fourche River near Elm Springs, SD ...................................212

11.118 06438500, Cheyenne River near Plainview, SD ..............................................213

11.119 06439000, Cherry Creek near Plainview, SD ......................................................214

$11.120 \quad 06439050$, Cherry Creek tributary near Avance, SD .......................................215

11.12106439060 , Cherry Creek tributary no. 2 near Avance, SD ..................................216

$11.122 \quad 06439080$, Cherry Creek tributary no. 3 near Avance, SD .................................217

$11.123 \quad 06439100$, Beaver Creek near Faith, SD ............................................................ 
$11.124 \quad 06439300$, Cheyenne River at Cherry Creek, SD ...............................................219

$11.125 \quad 06439400$, Plum Creek tributary near Milesville, SD ........................................220

11.126 06439430, Cottonwood Creek near Cherry Creek, SD .......................................221

11.127 06439960, Chantier Creek near Hayes, SD ......................................................222

11.128 06440200, South Fork Bad River near Cottonwood, SD ...................................223

11.129 06440850, Medicine Creek near Phillip, SD .....................................................224

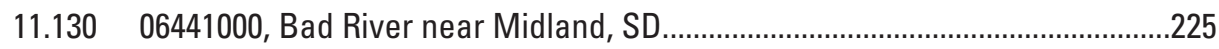

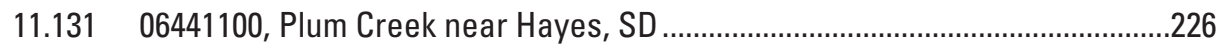

$11.132 \quad 06441110$, Plum Creek below Hayes, SD .....................................................227

11.133 06441200, Powell Creek tributary near Fort Pierre, SD ...................................228

11.134 06441500, Bad River near Fort Pierre, SD ..................................................229

11.135 06441530, Hilgers Gulch tributary near Pierre, SD .......................................230

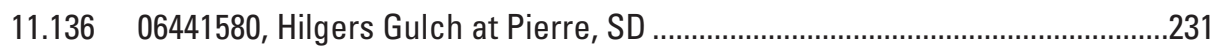

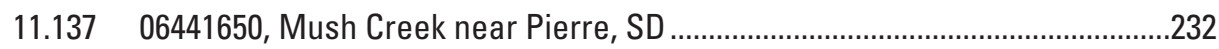

11.138 06441670, Missouri River tributary near Pierre, SD.........................................233

11.139 06441750, Missouri River tributary near Canning, SD ......................................234

$11.140 \quad 06442000$, Medicine Knoll Creek near Blunt, SD ............................................235

11.141 06442050, Missouri River tributary near De Grey, SD ....................................236

11.142 06442350, North Fork Medicine Creek near Vivian, SD ....................................237

11.143 06442380, Medicine Creek tributary near Vivian, SD ......................................238

$11.144 \quad 06442400$, Medicine Creek tributary no. 2 near Vivian, SD.............................239

11.145 06442500, Medicine Creek at Kennebec, SD ..................................................240

11.146 06442718, Campbell Creek near Lee's Corner, SD ............................................241

$11.147 \quad 06442850$, Elm Creek tributary near Ree Heights, SD ...................................242

11.148 06442900, Elm Creek near Gann Valley, SD ..................................................243

11.149 06442950, Crow Creek near Gann Valley, SD ..................................................244

$11.150 \quad$ 06445685, White River near Nebraska-South Dakota State line......................245

11.151 06445980, White Clay Creek near Oglala, SD ................................................246

11.152 06446000, White River near Oglala, SD ..........................................................

11.153 06446250, Porcupine Creek tributary near Rockyford, SD ...............................248

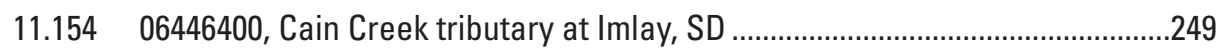

11.155 06446430, White River tributary near Conata, SD ...........................................250

$11.156 \quad 06446550$, White River tributary near Interior, SD ..........................................251

$11.157 \quad 06447000$, White River near Kadoka, SD ......................................................252

$11.158 \quad 06447500$, Little White River near Martin, SD ................................................253

$11.159 \quad 06448000$, Lake Creek above Refuge near Tuthill, SD .....................................254

$11.160 \quad 06449000$, Lake Creek below Refuge near Tuthill, SD ....................................255

$11.161 \quad 06449100$, Little White River near Vetal, SD ......................................................256

11.162 06449250, Spring Creek near St. Francis, SD ..............................................257

11.163 06449300, Little White River above Rosebud, SD...........................................258

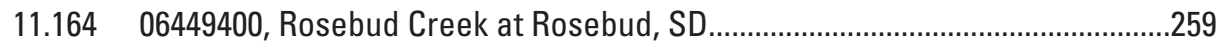

11.165 06449500, Little White River near Rosebud, SD .............................................260

11.166 06449700, Little Oak Creek near Mission, SD ...............................................261

11.167 06449750, West Branch Horse Creek near Mission, SD ...................................262

11.168 06450500, Little White River below White River, SD........................................263

11.169 06451750, Cottonwood Creek tributary near Winner, SD .................................264 


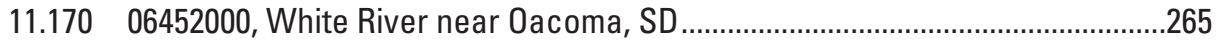

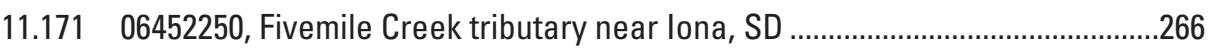

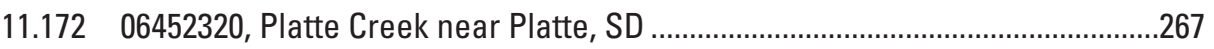

11.173 06453150, Choteau Creek tributary near Tripp, SD ...........................................268

11.174 06453250, Choteau Creek tributary near Wagner, SD ......................................269

11.175 06453255, Choteau Creek near Avon, SD .......................................................270

$11.176 \quad 06453400$, Ponca Creek near Naper, NE..........................................................221

11.177 06463900, Antelope Creek near Mission, SD ................................................272

11.178 06464100, Keya Paha River near Keyapaha, SD ...........................................273

11.179 06464500, Keya Paha River at Wewela, SD ....................................................274

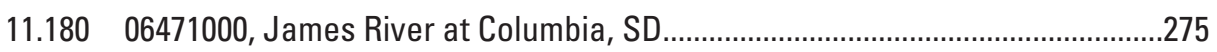

11.181 06471050, Elm River tributary near Leola, SD ...............................................276

11.182 06471200, Maple River at North Dakota-South Dakota State line ...................277

11.183 06471350, Maple River at Frederick, SD ..........................................................278

11.184 06471400, Willow Creek tributary near Leola, SD .............................................279

11.185 06471450, Willow Creek tributary near Barnard, SD ........................................280

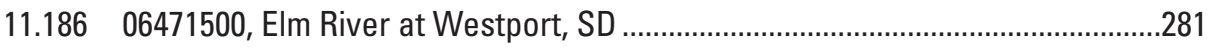

$11.187 \quad 06472000$, James River near Stratford, SD ......................................................282

11.188 06472200, Mud Creek tributary near Groton, SD ...............................................283

11.189 06472250, Mud Creek tributary no. 2 near Groton, SD .......................................284

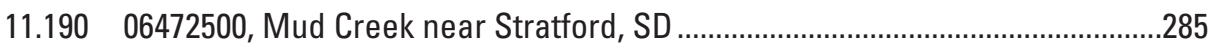

11.191 06473000, James River at Ashton, SD .......................................................286

11.192 06473300, Preachers Run tributary at Ipswich, SD ...........................................287

11.193 06473350, South Fork Snake Creek tributary near Seneca, SD ........................288

11.194 06473500, South Fork Snake Creek near Athol, SD ........................................289

11.195 06473700, Snake Creek near Ashton, SD .......................................................2.290

11.196 06473750, Wolf Creek near Ree Heights, SD .................................................291

11.197 06473800, Matter Creek tributary near Orient, SD ...............................................292

11.198 06473820, Shaefer Creek near Orient, SD ......................................................293

11.199 06473850, Shaefer Creek tributary near Orient, SD .........................................229

$11.200 \quad 06473880$, Shaefer Creek tributary near Miller, SD.........................................295

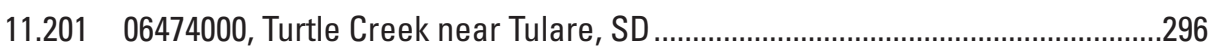

11.202 06474300, Medicine Creek near Zell, SD ......................................................297

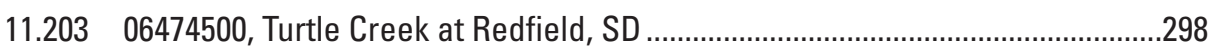

$11.204 \quad 06475000$, James River near Redfield, SD ......................................................29

11.205 06475500, Dry Run near Frankfort, SD ..............................................................300

11.206 06475550, Dry Run tributary near Frankfort, SD ..................................................301

11.207 06475850, Foster Creek tributary near Carpenter, SD ........................................302

$11.208 \quad 06475950$, Shue Creek tributary near Yale, SD ..................................................303

11.209 06476000, James River at Huron, SD ...........................................................304

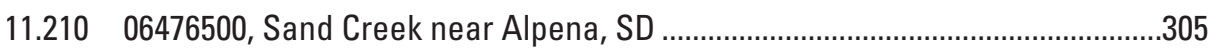

11.211 06477000, James River near Forestburg, SD .....................................................306

11.212 06477140, Rock Creek tributary near Roswell, SD ...........................................307

11.213 06477150, Rock Creek near Fulton, SD .........................................................308

11.214 06477400, Firesteel Creek tributary near Wessington Springs, SD ...................309

11.215 06477500, Firesteel Creek near Mount Vernon, SD ...........................................310 
11.216 06478000, James River near Mitchell, SD ........................................................311

11.217 06478050, Enemy Creek tributary near Mount Vernon, SD ................................312

11.218 06478052, Enemy Creek near Mitchell, SD ..........................................................313

11.219 06478200, Coffee Creek tributary near Parkston, SD .......................................314

$11.220 \quad$ 06478250, North Branch Dry Creek tributary near Parkston, SD .......................315

11.221 06478260, North Branch Dry Creek near Parkston, SD .......................................316

11.222 06478280, South Branch Dry Creek near Parkston, SD ......................................317

11.223 06478300, Dry Creek near Parkston, SD ...........................................................318

11.224 06478390, Wolf Creek near Clayton, SD ......................................................319

$11.225 \quad 06478400$, Lonetree Creek tributary near Kaylor, SD .......................................320

$11.226 \quad 06478500$, James River near Scotland, SD ......................................................321

11.227 06478540, Little Vermillion River near Salem, SD ............................................322

11.228 06478630, West Fork Vermillion River near De Smet, SD ...............................323

11.229 06478650, West Fork Vermillion River tributary near Monroe, SD .....................324

$11.230 \quad$ 06478690, West Fork Vermillion River near Parker, SD ......................................325

11.231 06478800, Saddlerock Creek near Canton, SD .................................................326

11.232 06478820, Saddlerock Creek tributary near Beresford, SD ..............................327

11.233 06478840, Saddlerock Creek near Beresford, SD .............................................328

$11.234 \quad$ 06478950, Ash Creek near Beresford, SD .........................................................329

11.235 06479000, Vermillion River near Wakonda, SD...............................................330

$11.236 \quad 06479010$, Vermillion River near Vermillion, SD ................................................331

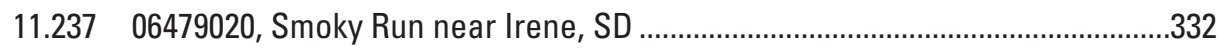

$11.238 \quad 06479200$, Big Sioux River near Ortley, SD .......................................................333

11.239 06479215, Big Sioux River near Florence, SD ...............................................334

11.240 06479240, Big Sioux River tributary no. 2 near Summit, SD ...............................335

11.241 06479260, Big Sioux River tributary no. 3 near Summit, SD .............................336

$11.242 \quad 06479350$, Soo Creek tributary near South Shore, SD ....................................337

$11.243 \quad 06479438$, Big Sioux River near Watertown, SD .................................................338

$11.244 \quad 06479500$, Big Sioux River at Watertown, SD ...................................................339

$11.245 \quad 06479515$, Willow Creek near Watertown, SD ................................................340

11.246 06479525, Big Sioux River near Castlewood, SD ..........................................341

11.247 06479529, Stray Horse Creek near Castlewood, SD ........................................342

$11.248 \quad 06479550$, Dolph Creek tributary near Lake Norden, SD...................................343

11.249 06479640, Hidewood Creek near Eestlline, SD ...................................................344

11.250 06479750, Peg Munky Run near Estelline, SD ...............................................345

$11.251 \quad 06479800$, North Deer Creek near Estelline, SD .................................................346

11.252 06479810, North Deer Creek tributary near Brookings, SD ................................347

11.253 06479900, Sixmile Creek tributary near Brookings, SD .....................................348

11.254 06479910, Sixmile Creek near Brookings, SD ……….....................................349

11.255 06479928, Battle Creek near Nunda, SD.............................................................350

11.256 06479950, Deer Creek near Brookings, SD ...................................................351

$11.257 \quad 06479980$, Medary Creek near Brookings, SD ..................................................352

11.258 06480000, Big Sioux River near Brookings, SD .............................................353

$11.259 \quad 06480400$, Spring Creek near Flandreau, SD ...................................................354

$11.260 \quad$ 06480650, Flandreau Creek above Flandreau, SD..........................................355

$11.261 \quad 06480720$, Bachelor Creek tributary near Wentworth, SD ...............................356 
11.262 06481000, Big Sioux River near Dell Rapids, SD ............................................357

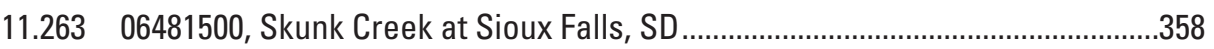

11.264 06482020, Big Sioux River at North Cliff Avenue at Sioux Falls, SD...................359

11.265 06482600, West Pipestone Creek tributary near Garretson, SD........................360

11.266 06482610, Split Rock Creek at Corson, SD ....................................................361

11.267 06482745, Beaver Creek at Valley Springs, SD ...............................................362

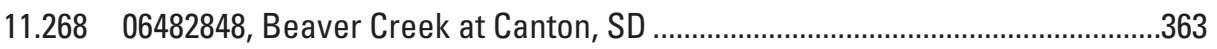

11.269 06482870, Little Beaver Creek tributary near Canton, SD .................................364

$11.270 \quad 06485500$, Big Sioux River at Akron, IA .......................................................365

11.271 06485550, West Union Creek near Alcester, SD ..............................................366

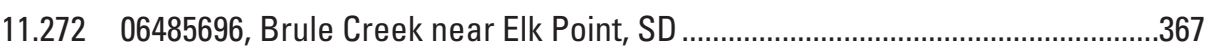

\section{Tables}

1. Description of regulating structures and diversions with potential to affect peak-flow characteristics for downstream gaging stations...

2. Selected information regarding station comparisons used in combining of records

3. Selected information regarding station comparisons used in extension of records

4. Selected information used in application of historical adjustments

5. Selected information for annual peak flows representative of the high-outlier population for the Black Hills region

6. Period-of-record and drainage-area characteristics for gaging stations, by major river basins

7. Station information and peak-flow frequency estimates for selected gaging stations

8. Annual peak-flow data for selected gaging stations (Excel spreadsheet). 63

9. Selected information regarding analytical procedures used in deriving peak-flow frequency estimates..... 


\section{Conversion Factors}

\begin{tabular}{lcl}
\hline Multiply & By & To obtain \\
\hline inch (in.) & Length & \\
inch (in.) & 2.54 & centimeter $(\mathrm{cm})$ \\
foot (ft) & 25.4 & millimeter $(\mathrm{mm})$ \\
mile (mi) & 0.3048 & meter (m) \\
\hline & 1.609 & kilometer $(\mathrm{km})$ \\
\hline acre & Area & \\
acre & 4,047 & square meter $\left(\mathrm{m}^{2}\right)$ \\
acre & 0.4047 & hectare $(\mathrm{ha})$ \\
acre & 0.4047 & square hectometer $\left(\mathrm{hm}^{2}\right)$ \\
square mile $\left(\mathrm{mi}^{2}\right)$ & 0.004047 & square $\mathrm{kilometer}\left(\mathrm{km}^{2}\right)$ \\
& 259.0 & hectare $($ ha) \\
\hline acre-foot $($ acre-ft) & Volume & \\
acre-foot (acre-ft) & 1,233 & cubic meter $\left(\mathrm{m}^{3}\right)$ \\
\hline & 0.001233 & cubic hectometer $\left(\mathrm{hm}^{3}\right)$ \\
\hline cubic foot per second $\left(\mathrm{ft}^{3} / \mathrm{s}\right)$ & Flow rate & \\
\hline
\end{tabular}

Vertical coordinate information is referenced to the National Geodetic Vertical Datum of 1929 (NGVD 29).

Horizontal coordinate information is referenced to the North American Datum of 1927 (NAD 27).

Altitude, as used in this report, refers to distance above the vertical datum.

Water year is the 12-month period, October 1 through September 30, and is designated by the calendar year in which it ends. Thus, the water year ending September 30, 2001 is called "water year 2001."

\section{Acronyms}

MOVE.1 maintenance of variance type I

SDDOT South Dakota Department of Transportation

USGS U.S. Geological Survey 



\title{
Peak-Flow Frequency Estimates Based on Data through Water Year 2001 for Selected Streamflow-Gaging Stations in South Dakota
}

\author{
By Steven K. Sando, Daniel G. Driscoll, and Charles Parrett
}

\begin{abstract}
Numerous users, including the South Dakota Department of Transportation, have continuing needs for peak-flow information for the design of highway infrastructure and many other purposes. This report documents results from a cooperative study between the South Dakota Department of Transportation and the U.S. Geological Survey to provide an update of peak-flow frequency estimates for South Dakota.

Estimates of peak-flow magnitudes for 2-, 5-, 10-, 25-, 50-, 100-, 200-, and 500-year recurrence intervals are reported for 272 streamflow-gaging stations, which include most gaging stations in South Dakota with 10 or more years of systematic peak-flow records through water year 2001. Recommended procedures described in Bulletin 17B were used as primary guidelines for developing peak-flow frequency estimates. The computer program PEAKFQ developed by the U.S. Geological Survey was used to run the frequency analyses. Flood frequencies for all stations were initially analyzed by using standard Bulletin 17B default procedures for fitting the log-Pearson III distribution. The resulting preliminary frequency curves were then plotted on a logprobability scale, and fits of the curves with systematic data were evaluated. In many cases, results of the default Bulletin 17B analyses were determined to be satisfactory. In other cases, however, the results could be improved by using various alternative procedures for frequency analysis.

Alternative procedures for some stations included adjustments to skew coefficients or use of user-defined low-outlier criteria. Peak-flow records for many gaging stations are strongly influenced by low- or zero-flow values. This situation often results in a frequency curve that plots substantially above the systematic record data points at the upper end of the frequency curve. Adjustments to low-outlier criteria reduced the influence of very small peak flows and generally focused the analyses on the upper parts of the frequency curves (10- to 500-year recurrence intervals).

The most common alternative procedures involved several different methods to extend systematic records, which was done primarily to address biases resulting from nonrepresentative climatic conditions during several specific
\end{abstract}

periods of record and to reduce inconsistencies among multiple gaging stations along common stream channels with different periods of record. In some cases, records for proximal stations could be combined directly. In other cases, the two-station comparison procedure recommended in Bulletin 17B was used to adjust the mean and standard deviation of the logs of the systematic data for a target station on the basis of correlation with concurrent records from a nearby long-term index station. In some other cases, a "mixed-station procedure" was used to adjust the log-distributional parameters for a target station, on the basis of correlation with one or more index stations, for the purpose of fitting the log-Pearson III distribution.

Historical adjustment procedures were applied to peakflow frequency analyses for 17 South Dakota gaging stations. A historical adjustment period extending back to 1881 (121 years) was used for 12 gaging stations in the James and Big Sioux River Basins, and various other adjustment periods were used for additional stations. Large peak flows that occurred in 1969 and 1997 accounted for 13 of the 17 historical adjustments. Other years for which historical peak flows were used include 1957, 1962, 1992, and 2001.

A regional mixed-population analysis was developed to address complications associated with many high outliers for the Black Hills region. This analysis included definition of two populations of flood events. The population of flood events that composes the main body of peak flows for a given station is considered the "ordinary-peaks population," and the population of unusually large peak flows that plot substantially above the main body of peak flows on log-probability scale is considered the "high-outlier population." All peak flows assigned to the high-outlier population were identified as high outliers by the Grubbs-Beck outlier test. For each gaging station, the final frequency curve was determined by using joint-probability theory to combine the ordinary-peaks probability distribution for the gaging station with the regional high-outlier probability distribution. This nonstandard application of the mixed-population procedure in Bulletin 17B was able to accommodate the different populations of flood events that have occurred in the Black Hills region. 


\section{Introduction}

Numerous users, including the South Dakota Department of Transportation, have continuing needs for peak-flow information for the design of highway infrastructure and many other purposes. SDDOT has been a long-term cooperator with the U.S. Geological Survey (USGS) in operating partial-record crest-stage gaging stations throughout South Dakota that provide peak-flow data for numerous locations where continuousrecord stations are not operated. This report documents results from a cooperative study between SDDOT and USGS to provide an update of statewide peak-flow frequency estimates.

The purpose of this report is to present peak-flow frequency estimates for 272 streamflow-gaging stations in South Dakota based on data through water year 2001. Estimates of peak-flow magnitudes for 2-, 5-, 10-, 25-, 50-, 100-, 200-, and 500 -year recurrence intervals are reported. The wide variety of hydrogeologic conditions that affect peak-flow characteristics in South Dakota are described in this report. The procedures used for the frequency analyses are documented. Characteristics of gaging stations and frequency analyses by major river basin also are provided.

\section{Peak-Flow Frequency Estimates}

Estimates of peak-flow magnitudes for 2-, 5-, 10-, 25-, 50-, 100-, 200-, and 500-year recurrence intervals are reported for 272 gaging stations. This includes almost all of the gaging stations in South Dakota with 10 or more years of systematic peak-flow records through water year 2001 and includes both continuous- and partial-record stations. Within this report, all streamflow data are referenced to water years. Estimates are not reported for several stations with sufficient record, primarily because of proximity to another station along the same stream reach for which frequency estimates were more reliable because of longer available record.

Site information for all gaging stations is presented in table 7 in Appendix 1 at the back of this report, and locations of stations are shown in figure 1. Stations in table 7 are arranged according to the USGS downstream order system and are grouped according to major river basins. The first two stations drain to the Red River of the North, which drains to Hudson Bay, and the next group of stations is within the Minnesota River Basin, which drains to the Mississippi River. The next group in table 7 is the "minor tributaries to Missouri River (group 1)," which includes the first group of stations presented in downstream order that are not within any of the other designated river basins. Most of the drainage areas for stations grouped as minor tributaries to the Missouri River are less than 1,000 square miles $\left(\mathrm{mi}^{2}\right)$, and the minor tributary stations are interspersed in downstream order among the remaining major river basins as groups 1-6. All the remaining major river basins drain to the Missouri River and include the Grand, Moreau, Cheyenne, Bad, White, James, Vermillion, and Big Sioux River Basins.
Table 7 identifies the period of systematic record available for each station and the period of record that was used for analysis, which is different for some stations because of various reasons. Estimates of peak-flow magnitudes for 2-, 5-, 10-, 25-, 50-, 100-, 200-, and 500-year recurrence intervals also are included in table 7. Procedures regarding development of peak-flow frequency estimates are described in subsequent sections. Graphs showing frequency curves fitted to systematic data and a time-series plot for each station are provided in Appendix 2 at the back of this report. All peak flows less than or equal to 0.1 are plotted as 0.1 on these graphs.

Systematic peak-flow records through 2001 for all stations considered are provided in table 8 in Appendix 1 at the back of this report. Table 8 is an Excel spreadsheet with a readme worksheet, followed by worksheets for each of the major river basins. Three separate worksheets are included for the Cheyenne River Basin and provide breakdowns for stations located (1) along the main stems of the Cheyenne and Belle Fourche Rivers; (2) along tributaries upstream from the confluence of the Cheyenne and Belle Fourche Rivers; and (3) along tributaries downstream from the confluence. Table 8 includes several stations for which available data were used for various purposes such as combination of records or interpretation of peak-flow characteristics for nearby gaging stations, but for which peak-flow frequency estimates were not derived. Peak-flow records for stations in South Dakota are available online at http://nwis.waterdata.usgs.gov/sd/nwis/peak.

\section{Hydrogeologic Considerations Regarding Peak- Flow Frequency Estimates}

Peak-flow characteristics are affected by a wide variety of hydrogeologic conditions in South Dakota. Sando (1998) identified seven hydrologic subregions within South Dakota for a statewide regionalization of peak-flow characteristics. Selection of the subregions was substantially influenced by the primary and secondary physiographic subdivisions shown in figure 2 .

Land-surface altitudes range from about 1,000 feet (ft) above National Geodetic Vertical Datum of 1929 (NGVD 29) in the northeastern part of the State to more than 7,000 ft above NGVD 29 in some parts of the Black Hills. The largest relief occurs in the Black Hills, where topography is relatively steep in many locations and general altitudes drop to about 3,000 to 4,000 ft above NGVD 29 in surrounding areas. Most of western South Dakota is well drained, and contributing drainage areas are equal to total drainage areas for most gaging stations (table 7). The primary exceptions are within the Little White River Basin, which is a major tributary to the White River.

In contrast, many parts of eastern South Dakota are relatively flat and poorly drained. Large volumes of depression storage can occur in the form of large or small lakes, large or small wetlands, or undrained depressions in the middle of fields. A distinguishing feature is the Coteau des Prairies 


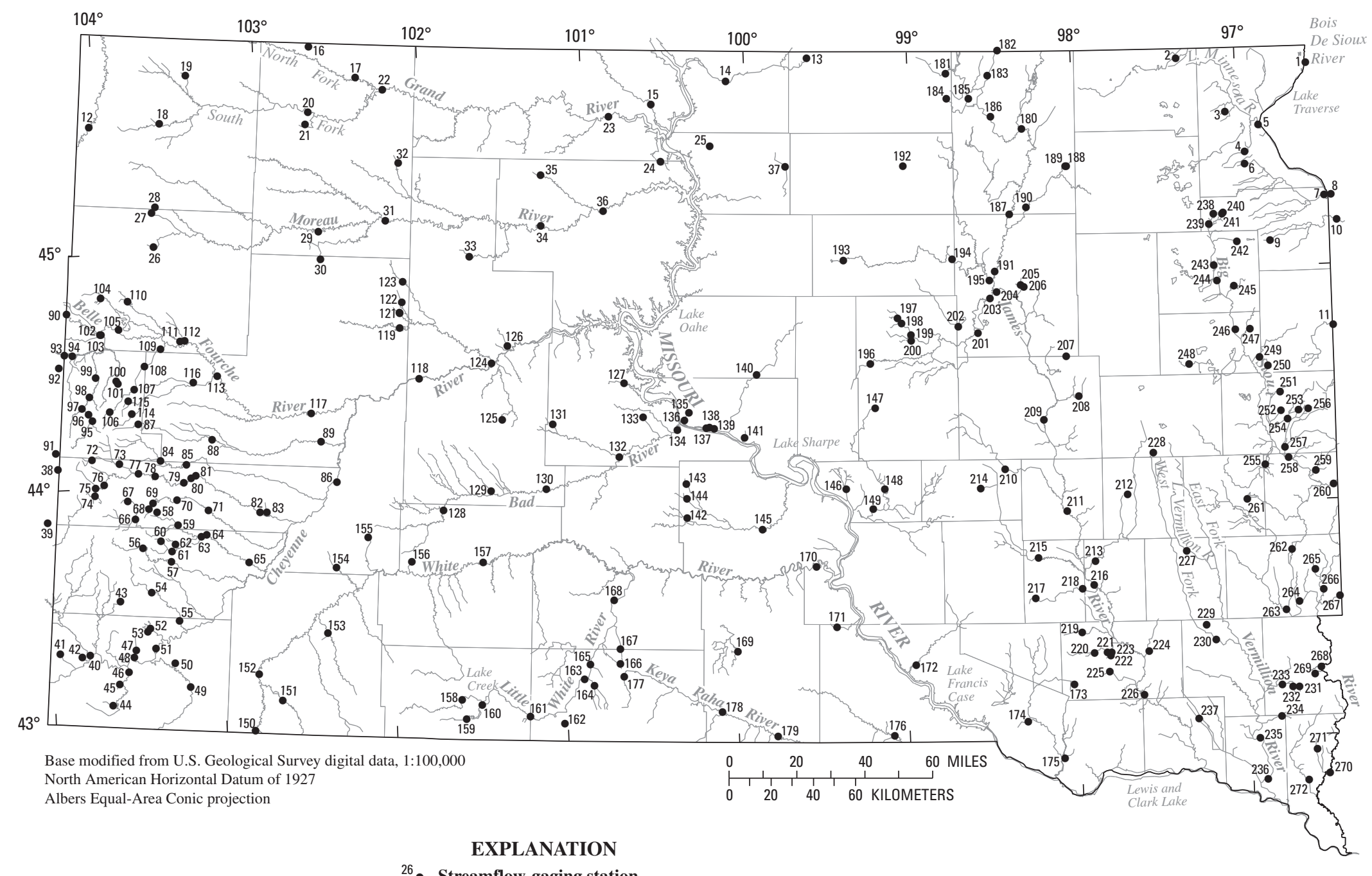

${ }^{26}$ - Streamflow-gaging station-

Number is map number in table 7

Figure 1. Locations of selected streamflow-gaging stations in South Dakota. 


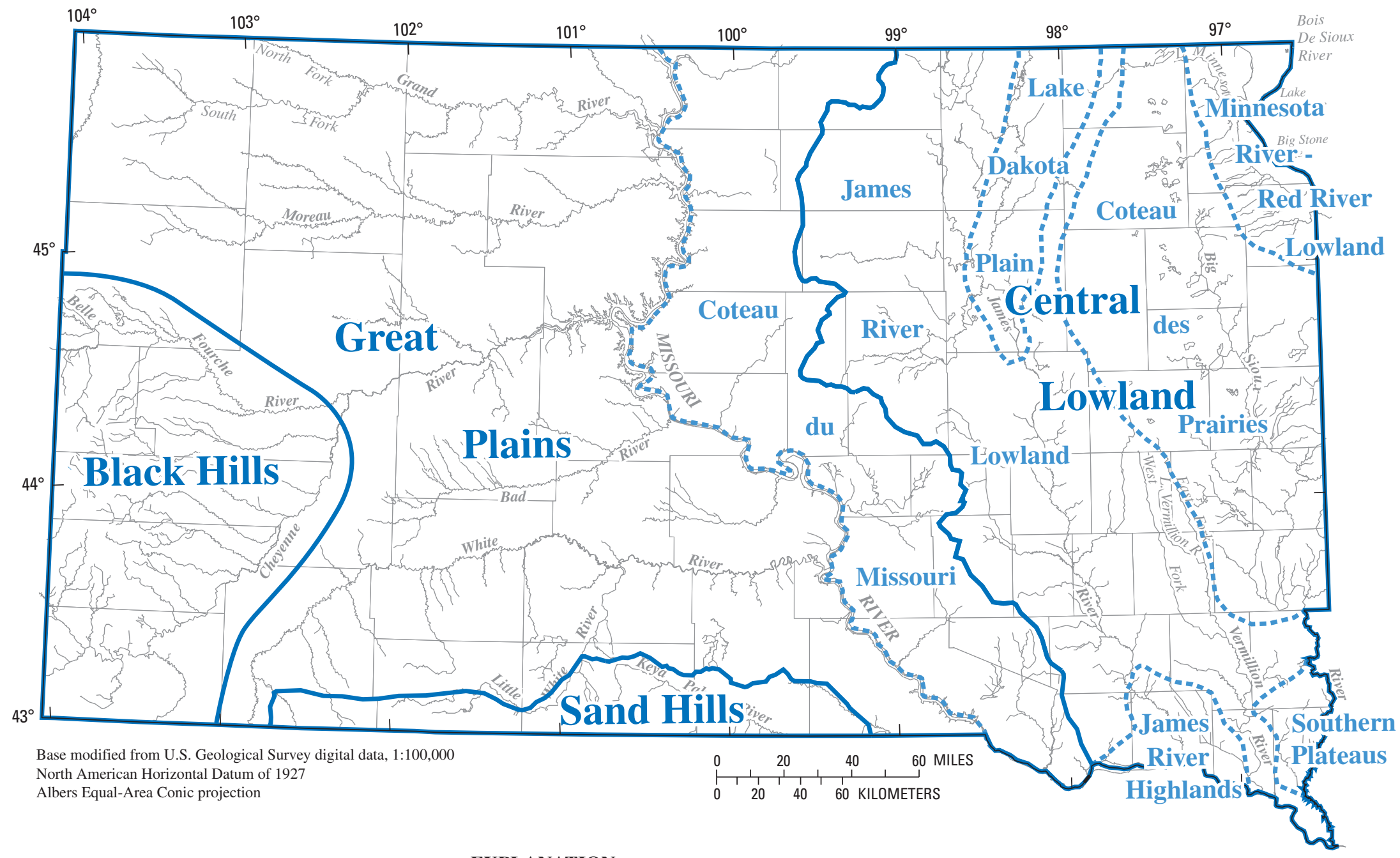

Figure 2. Main physiographic divisions of South Dakota (modified from Flint, 1955; Fenneman, 1946). 
(fig. 2), which is a massive highland area that extends along much of the eastern border of South Dakota and is characterized by numerous lakes and smaller wetlands. A continental divide is located in extreme northeastern South Dakota off the northeastern shoulder of the Coteau des Prairies and separates small headwater areas of the Red River of the North and the Minnesota River (tributary to the Mississippi River). Large areas within the James, Vermillion, and Big Sioux River Basins are considered noncontributing (table 7). Many other areas can be noncontributing during low-storage conditions but contributing when spill elevations of depressions are exceeded. In addition, the very small channel gradients in some parts of eastern South Dakota frequently result in backwater conditions during flood stages at some stations (Thompson, 2007). Extreme examples occur within upstream reaches of the James River Basin, where reverse (upstream) flow as much as thousands of cubic feet per second $\left(\mathrm{ft}^{3} / \mathrm{s}\right)$ has been measured at stations 06471000 and 06473000 (U.S. Geological Survey, 2002). Because of these conditions, unit peak flows (peak discharges per unit area) in many drainages in eastern South Dakota can be much smaller than for comparably sized drainages in other parts of the State.

Peak flows in eastern South Dakota can be strongly influenced by antecedent moisture conditions, which can be affected by relatively long-term climatic conditions (timeframes of weeks, months, and even years). All climatic data within this report were obtained online (South Dakota State University, 2007) and are referenced to calendar years. Peak-flow characteristics are further influenced by a gradient in general climatic conditions across the State. Subhumid conditions typically occur in southeastern and extreme eastern South Dakota, but grade westerly to semiarid conditions, with substantial influence on both precipitation and evapotranspiration potential. A tendency also exists for larger percentages of annual precipitation during winter months (typically occurring as snowfall) in eastern South Dakota, along with generally lower winter temperatures, relative to western South Dakota (South Dakota State University, 2007). As a result, large volumes of water can accumulate in the form of snow and ice over large parts of eastern South Dakota during some winters, and depression storage can be substantially filled during spring thaw. Thus, annual peak flows for many gaging stations in eastern South Dakota can be strongly influenced by snowmelt during the spring thaw, or snowmelt in combination with spring rains that might occur during or soon after spring thaw, while depression storage remains high and soils may remain saturated.

The general gradient in climatic conditions contributes to distinctive differences in land-use patterns between eastern and western South Dakota (National Agricultural Statistics Service, 2007), which also can influence peak-flow characteristics. Generally higher humidity and higher average annual precipitation in eastern South Dakota than in western South Dakota are much more amenable to production of row crops, such as corn and soybeans, that have high water demand. Small grain farming, various hay crops, and grazing lands typically occupy agricultural areas with progressively poorer soils, steeper topography, or areas with decreasing precipitation potential. In contrast, western South Dakota is dominated by grazing lands, with large areas also devoted to wheat production in some locations. Extensive corn production in western South Dakota generally is limited to the south-central part of the State and a few scattered irrigated areas. Most dryland row cropping is for sunflowers or fodder crops such as sorghum and millet.

All of South Dakota can be subject to both short- and long-term drought conditions, and drought potential generally increases in a westerly direction across the State. Substantial reductions in annual peak flows can occur during drought periods for drainages with large volumes of depression storage, which are especially abundant in eastern South Dakota, because of increasing availability of storage space as water storage is depleted. In contrast, progressive depletion of vegetative cover during prolonged multiyear drought periods might actually contribute to increased peak-flow potential, especially in western South Dakota.

Annual peak flows tend to be highly correlated between many gaging stations in eastern South Dakota, whereas correlations for western South Dakota generally are much weaker, except between multiple stations on the main stems of larger channels. Thus, various procedures for extension of peak-flow records were used more frequently for stations in the eastern part of the State than for stations in the western part. Many of the record extensions were performed to address substantial biases that exist for two specific periods. Many partial-record stations were operated in the State during 1970-79 (table 7), which was dominated by particularly dry climatic conditions in eastern South Dakota (South Dakota State University, 2007). Large peak flows are notably underrepresented during this period for most stations with long-term records, which results in a potential bias towards underestimating peak flows for larger recurrence intervals for stations with records only for 1970-79. Conversely, many other stations in eastern South Dakota have relatively short records that include 1992-2001, which was a prolonged period of particularly wet climatic conditions. Large peak flows tend to be overrepresented during this period, which can result in a potential bias towards overestimating peak flows.

Figure 3 shows annual precipitation and peak-flow characteristics for selected sites in eastern South Dakota for two 10-year periods (1970-79 and 1992-2001) relative to a longterm period (52 years; 1950-2001). Graph A shows statistical distributions of annual precipitation at Huron (South Dakota State University, 2007), which is near the center of eastern South Dakota (near map number 209; fig. 1). Also shown in figure 3 are statistical distributions of geometric means (that is, the means of the base- 10 logarithms retransformed into arithmetic space) of annual peak flows (graph $B$ ) and standard deviations of the base-10 logarithms of the annual peak flows (graph $C$ ) of nine long-term gaging stations (06473000, 06475000, 06476000, 06477000, 06478500, 06479000, 06481000, 06481500, and 06482020; map numbers 191, 204, 
209, 211, 226, 235, 262, 263, and 264 in fig. 1). These stations are on both tributary and main-stem reaches in the James, Vermillion, and Big Sioux River Basins and have contributing drainage areas ranging from about 613 to $16,500 \mathrm{mi}^{2}$.

Precipitation at the index station generally was lower during 1970-79 than during the long-term (1950-2001) period (graph $A$ of fig. 3). Median annual precipitation for 1970-79 was 18.2 inches (in.), which was about 2 in. less than during the long-term period and resulted in below-normal soil moisture and low water levels in depressions. Conversely, during 1992-2001, median annual precipitation (22.9 in.) was about $3 \mathrm{in}$. larger than during the long-term period, and persistent wet conditions resulted in above-normal soil moisture and high water levels in depressions. The median peakflow geometric mean for the nine long-term gaging stations (graph $B$ ) was smaller for 1970-79 (about 1,230 $\mathrm{ft}^{3} / \mathrm{s}$ ) than for the long-term period (about 1,600 $\mathrm{ft}^{3} / \mathrm{s}$ ). The median peakflow geometric mean for 1992-2001 (about 4,770 $\mathrm{ft}^{3} / \mathrm{s}$ ) was substantially larger than for the long-term period. Perhaps the most substantial difference in peak-flow characteristics was much smaller standard deviations of the base-10 logarithms (graph $C$ ) for both of the anomalous 10-year periods than for the long-term period, which indicates substantially less variability in peak flows during both 10 -year periods than during the long-tem period.

The influence of variable climatic conditions is shown in figure 4 by example frequency curves for three long-term gaging stations in eastern South Dakota. Systematic records and frequency curves were plotted by using annual peak-flow data for (1) the entire 1950-2001 period, (2) 1970-79, and (3) 1992-2001. Frequency curves for 1970-79 data generally plot substantially below the curves for 1950-2001 data for recurrence intervals greater than about 5 years. Frequency curves for the 1992-2001 data plot above the curves for 1950-2001 data for the smaller recurrence intervals; however, the curves begin to converge at larger recurrence intervals. Where possible, record-extension procedures were used to compensate for possible biases in peak-flow frequency estimates for short-term stations that have periods of record entirely or predominantly in the two anomalous climatic periods.

Global climate change recently has been widely recognized as a potential agent for long-term changes in hydrologic conditions. Although potential exists for associated changes in peak-flow characteristics in South Dakota, justification for modifying peak-flow frequency estimates on this basis would be speculative. Numerous changes in land use also may have affected peak-flow characteristics in South Dakota; however, most changes are relatively transient and attempting to account for such changes generally would not be possible. For example, implementation of the Conservation Reserve Program (U.S. Department of Agriculture, 2007) during the 1980s substantially increased vegetative cover over large areas, which might have resulted in decreased peak-flow potential. Enrollments in this program began decreasing somewhat during the late 1990s, however, which might have produced an opposite effect.

Peak-flow characteristics have changed substantially for many rivers in South Dakota because of reservoir construction. The Missouri River is highly regulated by a series of large reservoirs constructed during the 1950s. Probability-based frequency estimates for this system are not applicable and thus are not provided for any gaging stations along the main stem of the Missouri River. Many smaller streams in the State also are regulated, and considerations regarding frequency analyses for regulated stations are described in the subsequent section "Procedures for Gaging Stations Affected by Regulation."

Changes in peak-flow characteristics also may have resulted from construction of thousands of relatively small reservoirs (locally referred to as "stock reservoirs" or "stock dams"), which exist in all the major river basins listed in table 7. Culler and Peterson (1953) reported a large reduction in annual runoff for the Cheyenne River that was attributed to construction of numerous stock reservoirs prior to 1950. Mean annual runoff for the Cheyenne River near Hot Springs (station 06400500) was 497,200 acre-feet (acre-ft; 1.07 in. per unit area) during 1915-20, compared with 101,300 acre-ft (0.22 in. per unit area) during 1944-50. Mean annual precipitation over the drainage basin for the same periods was estimated as 17.66 and 17.42 in., respectively. Although changes in annual runoff as a result of stock reservoir construction have been documented, changes in peak-flow characteristics resulting from stock reservoir construction are likely to be highly variable and transient. Small peak flows can be entirely contained by stock reservoirs in some drainages, and virtually all peak flows might be attenuated to at least some extent; however, effects on larger peak flows might be relatively small, especially during flow events when reservoirs are already at or near capacity. Additionally, peak flows can be accentuated by stock reservoir failures, which can be a frequent occurrence, as visually evidenced by numerous failed stock reservoirs throughout the State. No attempt was made within this report to account for potential changes resulting from stock reservoir construction because (1) accounting for such changes would be generally infeasible and (2) peak-flow records for most gaging stations largely post-date primary periods of stock reservoir construction.

Peak-flow potential probably has increased in parts of eastern South Dakota following draining of wetlands and other improvements to drainage. Again, no attempt was made to account for such changes because of the general infeasability of the effort and the fact that many of the changes pre-dated the collection of peak-flow records.

Geology is very diverse within South Dakota, and effects of geology on peak-flow characteristics can be highly variable. Most of South Dakota east of the Missouri River has been glaciated (fig. 5), and a very wide variety of surficial deposits can occur within very small areas (Martin and others, 2004), with potential for substantial influence on infiltration capacity and associated effects on peak-flow characteristics. The majority 

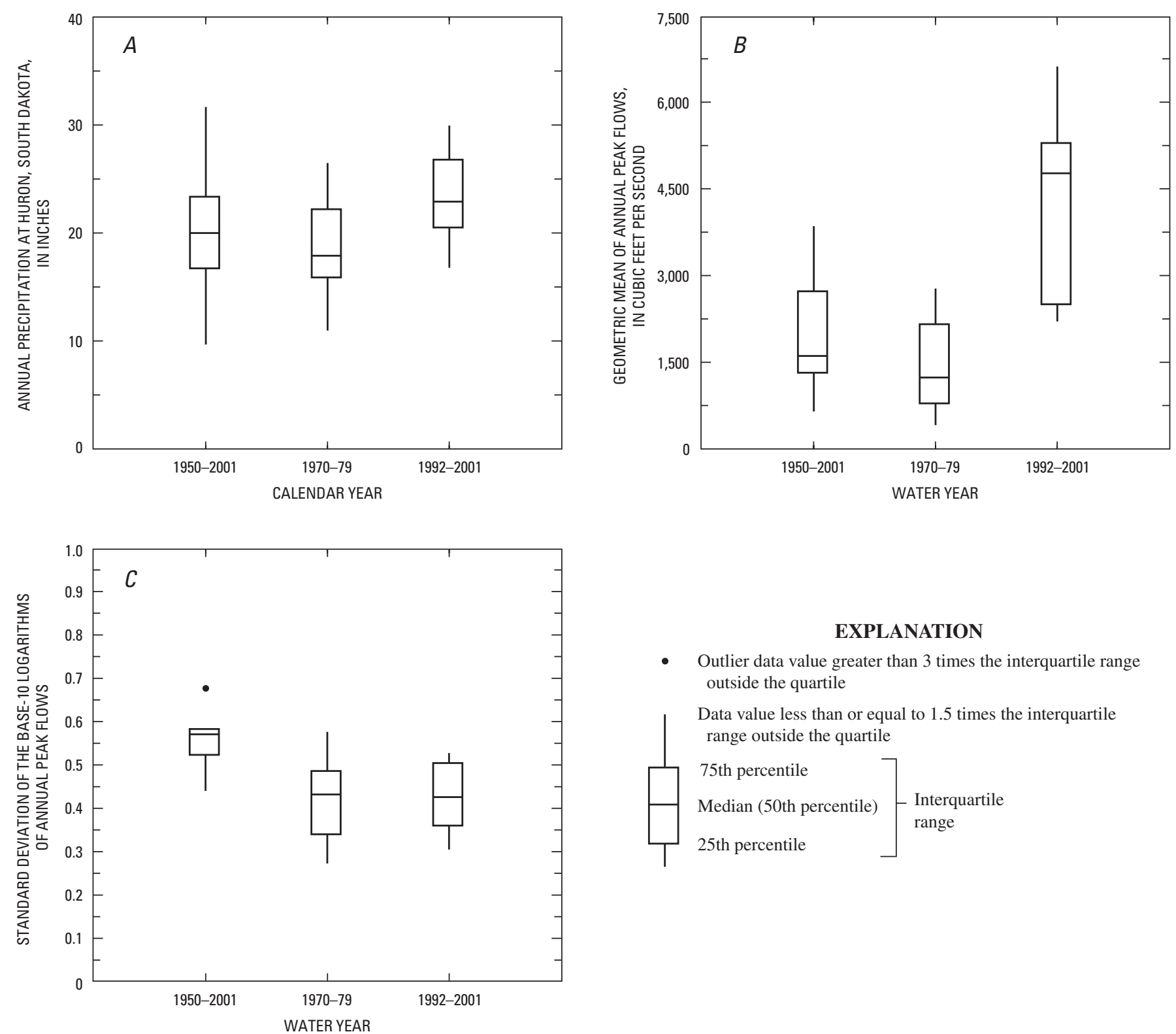

\section{EXPLANATION}

- Outlier data value greater than 3 times the interquartile range outside the quartile

Data value less than or equal to 1.5 times the interquartile range outside the quartile

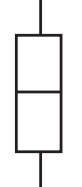
$\left.\left.\begin{array}{l}\text { 75th percentile } \\ \text { Median (50th percentile) } \\ \text { 25th percentile }\end{array}\right]-\begin{array}{l}\text { Interquartile } \\ \text { range }\end{array}\right]$

Figure 3. Relations among annual precipitation and peak-flow characteristics for short- and long-term periods for selected sites in eastern South Dakota. Statistical distributions are shown for $(A)$ annual precipitation at Huron (South Dakota State University, 2007) and for $(B, C)$ selected annual peak-flow characteristics of nine long-term gaging stations.

of glaciated areas in South Dakota are dominated by glacial tills, which generally have high clay content and low infiltration capacity. However, some glaciated areas have surficial deposits of much coarser-grained materials, such as sands and gravels, that typically have higher infiltration capacities.

The Cretaceous-age Pierre Shale is the dominant geologic outcrop in western South Dakota, and small outcrops of this formation also occur in a corridor just east of the Missouri River (fig. 5). Many soils associated with the Pierre Shale are clay-rich and have low infiltration capacity. The Missouri River is deeply entrenched, with relatively high relief along the river, with the general exception of extreme southeastern
South Dakota. Many outcrops of the Pierre Shale support little vegetative cover along the "breaks" of the Missouri River and along several other major tributaries to the Missouri River, which results in particularly high peak-flow potential. Similar river breaks also occur in various other geologic outcrops throughout western South Dakota. Sando (1998) included such areas as a separate subregion in regionalizing statewide peakflow characteristics and noted larger uncertainties in peak-flow frequency estimates for these areas.

The common occurrence of clays and siltstones in outcrops of several other Cretaceous formations (fig. 5) can result in relatively high peak-flow potential in other relatively large 

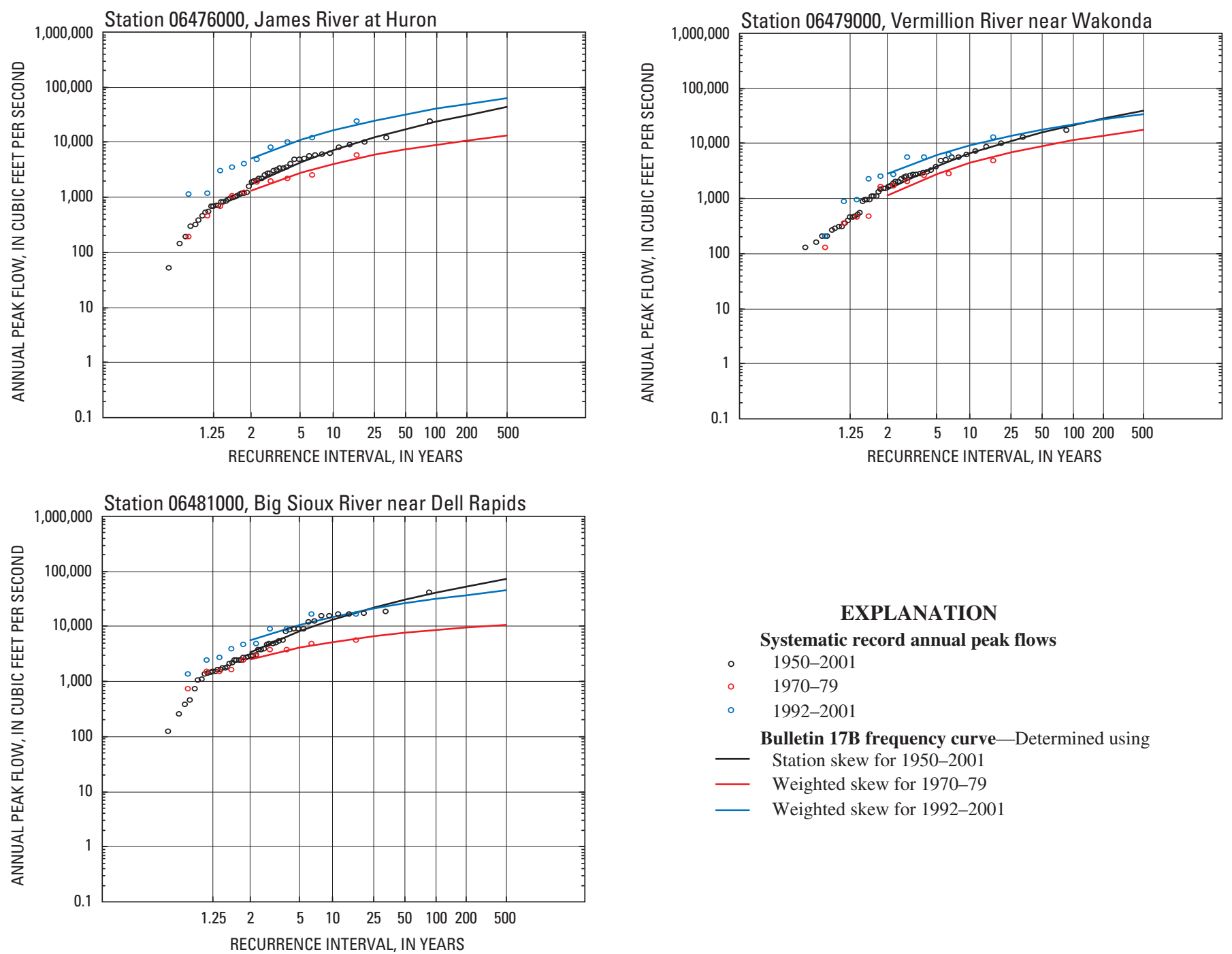

Figure 4. Peak-flow frequency information for three long-term stations in eastern South Dakota based on data for three different time periods (1950-2001, 1970-79, and 1992-2001).

parts of western South Dakota. "Badlands" topographies occur in several drainages in western South Dakota (predominantly within the White River, Cheyenne, and Bad River Basins) where the Tertiary-age White River Group crops out (Martin and others, 2004). Peak-flow potential can be especially high in such areas because of very steep slopes, minimal vegetation cover, and highly erodible clay soils. In contrast, infiltration capacities can be particularly high in the vicinity of the Sand Hills physiographic division (fig. 2) due to Quaternary-age deposits of wind-blown sands and the presence of abundant sandy soils derived from the Tertiary-age Ogallala Formation (Martin and others, 2004).

In the Black Hills physiographic division (fig. 2), geology is highly complex (Martin and others, 2004) and has distinctive effects on annual peak flows. In this report, the Black Hills region is defined as that part of the Cheyenne River Basin that is upstream from the confluence of the
Cheyenne and Belle Fourche River main stems. Driscoll and Carter (2001) identified five hydrogeologic settings that have substantial influence on general streamflow characteristics in the Black Hills region. Examination of these settings provides useful insights regarding peak-flow characteristics in the Black Hills region. The five settings are represented by only four areas within figure 6 because overlap commonly occurs within areas for the "loss-zone" and "artesian-spring" settings.

The "limestone headwater" setting occurs within outcrops of the Mississippian-age Madison Limestone and the Pennsylvanian- and Permian-age Minnelusa Formation within the "Limestone Plateau" area along the South Dakota/ Wyoming border. The Madison Limestone and Minnelusa Formation are the dominant formations within the Paleozoic rocks shown in figure 5. Perennial streamflow in this area typically only occurs where large springs exist around the periphery of the Limestone Plateau, and direct runoff is very uncommon in 


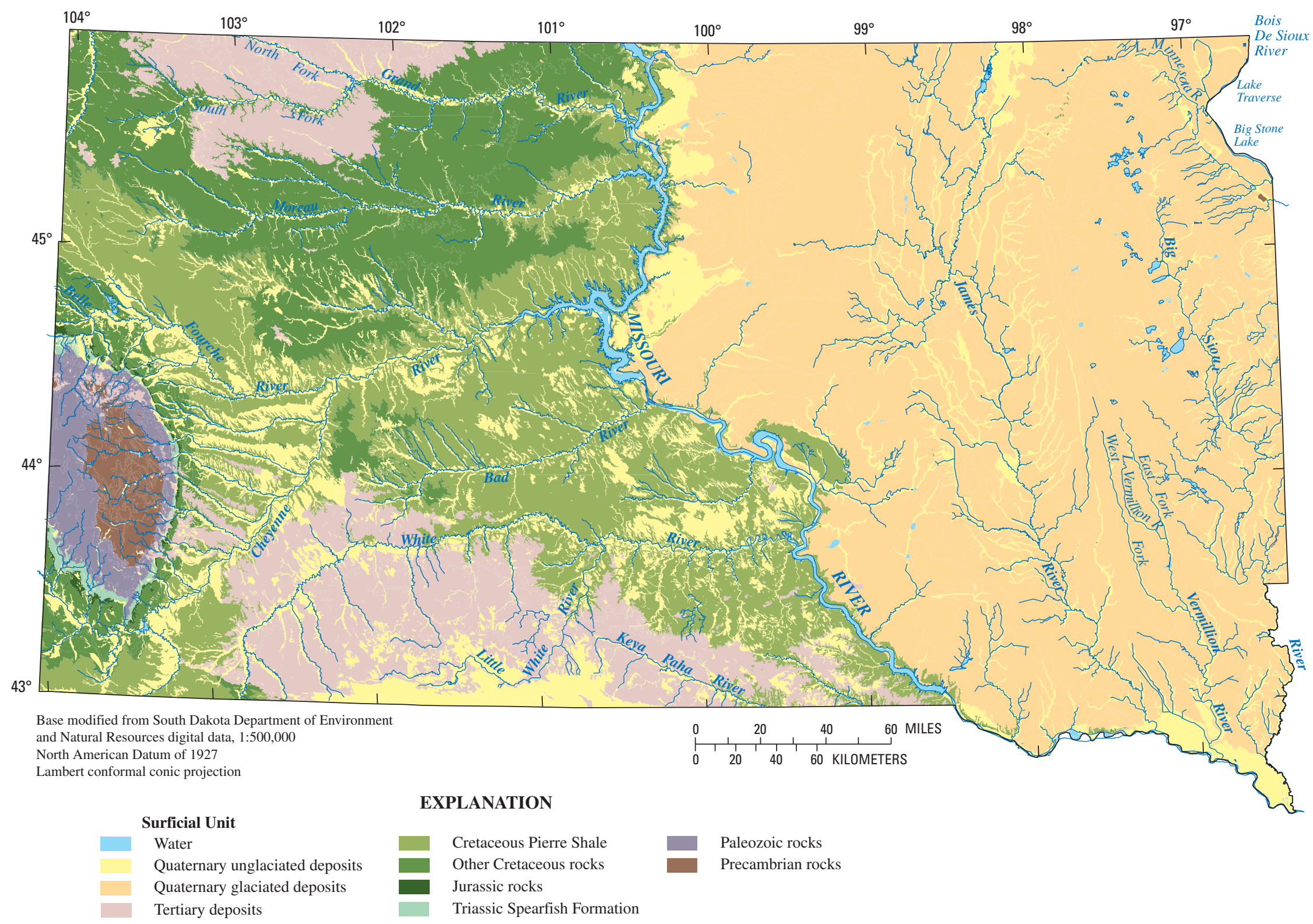

Figure 5. Generalized surficial geology of South Dakota (modified from Martin and others, 2004). 


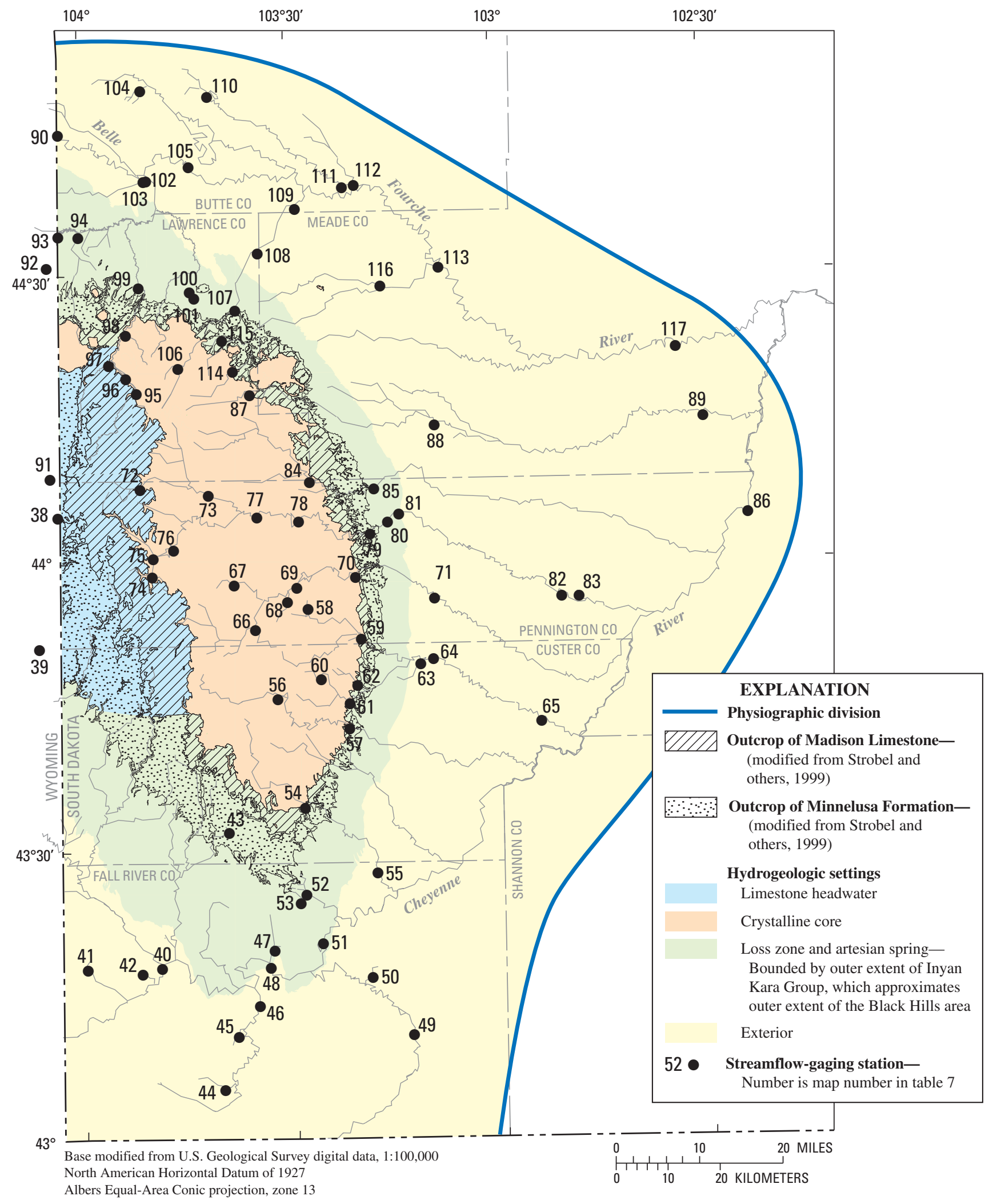

Figure 6. Hydrogeologic settings for the Black Hills region (modified from Driscoll and Carter, 2001). 
most of the Limestone Plateau area (Driscoll and Carter, 2001) because of extremely high infiltration capacities within the Madison Limestone and within some parts of the Minnelusa Formation. Low topographic relief also contributes to generally low peak-flow potential in this area, and it also is possible that maximum precipitation potential within this high-altitude area might be somewhat less than at lower altitudes. This relation has been documented for other mountainous areas (Jarrett and Costa, 1988; Jarrett, 1993).

The "crystalline core" setting is encircled by the outcrop band of the Madison Limestone and Minnelusa Formation (fig. 6) and is dominated by Precambrian igneous and metamorphic rocks (Driscoll and Carter, 2001). Perennial (or nearperennial) flow occurs in many streams in the crystalline-core setting; however, base flow typically constitutes only a small part of the annual flow volume for most stream reaches within this setting. Daily mean flows for streams used by Driscoll and Carter (2001) to characterize this setting varied by as much as several orders of magnitude, compared with less than one order of magnitude for most streams used to characterize the limestone-headwater setting. This indicates much more direct response to short-term precipitation input and corresponds with substantially larger peak-flow potential, relative to the limestone-headwater setting.

Downgradient from the crystalline-core area is the "loss zone" setting, where streamflow losses occur as streams cross outcrops of the Madison Limestone and Minnelusa Formation (Hortness and Driscoll, 1998). Streamflow occurs only when upstream flows exceed the channel infiltration capacity or "loss threshold," which is as much as many tens of cubic feet per second for some streams (Hortness and Driscoll, 1998). Thus, substantial diminishment of relatively small peak flows can occur during periods when channels within and downstream from loss zones are dry during low-flow conditions, prior to the onset of higher-flow conditions. Effects on relatively large peak flows, however, typically are minimal. Generation of direct runoff also can be somewhat limited in outcrop areas within the loss-zone setting (Miller and Driscoll, 1998), which is composed primarily of the Madison Limestone and Minnelusa Formation. However, this effect probably is less pronounced than in the limestone-headwater setting, where relief generally is milder than in the loss-zone setting.

Within and downgradient from the loss zone setting is the "artesian spring" setting (Driscoll and Carter, 2001). Perennial flow occurs in some stream channels where flow is discharged by artesian springs. Effects on peak-flow characteristics are minimal and generally are limited to maintaining saturation of individual alluvial channels where artesian springs exist. Many other stream channels do not have artesian springs, however, and such channels typically are dry except when upstream flow exceeds "loss thresholds" (Hortness and Driscoll, 1998).

Surficial geology varies widely within the "exterior" hydrogeologic setting, which extends beyond the area shown in figure 6 and includes all of the Cheyenne River Basin upstream from the confluence of the Cheyenne and Belle Fourche Rivers. Many of the bedrock formations in this setting are Cretaceous shales (fig. 5), and associated soils in many locations have low infiltration capacities. Daily mean flows for streams used by Driscoll and Carter (2001) to characterize this setting varied by as much as five orders of magnitude, which is larger than for any of the other hydrogeologic settings in the Black Hills area. Extensive alluvial deposits, terrace deposits, and other bedrock formations also exist in many areas (Martin and others, 2004) and can influence peak-flow characteristics. Flood plains along major stream channels within the exterior setting typically are much broader than those for most streams that head within the higher altitudes of the Black Hills in the upgradient settings. This typically results in increasing potential for attenuation of some peak flows in a downstream direction, which can be further accentuated for some streams by other associated factors such as decreasing channel gradient, increasing channel sinuosity, and presence of numerous abandoned meanders. Similar generalities do not necessarily apply to stream channels that head primarily within the exterior setting.

Precipitation patterns in the Black Hills are strongly affected by orographic effects, with average annual precipitation increasing with altitude (Driscoll and Carter, 2001). Orographic effects also contribute to increased thunderstorm formation in the area and can strongly influence thunderstorm formation and behavior, especially around the flanks of the Black Hills uplift (Schwarz and others, 1975).

\section{Procedures for Frequency Analyses}

Peak-flow frequency estimates for 272 gaging stations (table 7) were developed by using various specific procedures that are described in detail within the following section of this report. Selected information regarding application of these specific procedures for all stations is summarized in table 9 in Appendix 1 at the back of this report.

\section{General Procedures for Fitting the Log-Pearson Type III Probability Distribution}

Most Federal agencies and many State, local, and private entities follow procedures described in Bulletin 17B "Guidelines for Determining Flood Flow Frequency" (U.S. Interagency Advisory Council on Water Data, 1982; hereinafter referred to as Bulletin 17B) for developing peak-flow frequency estimates. Bulletin 17B uses the log-Pearson III probability distribution, which is fit by using the mean, standard deviation, and skew of the logs of the annual flood series (maximum flood peak for each year) for a given gaging station. Recommended procedures described in Bulletin 17B were used as primary guidelines for developing the peak-flow frequency estimates presented in this report, and the computer program PEAKFQ developed by the U.S. Geological Survey (Flynn and others, 2006) was used to run the frequency analyses. 
Peak-flow frequencies initially were analyzed for all stations by using standard Bulletin 17B default procedures for fitting the log-Pearson III distribution. The resulting preliminary frequency curves were next plotted on a log-probability scale in conjunction with the systematic data, for which plotting points were determined with the use of the Cunnane formulation, as described by Helsel and Hirsch (1992). Fits of the preliminary frequency curves with the systematic data were then evaluated. In many cases, fits of the default Bulletin 17B analyses were determined to be satisfactory. In these cases, a single frequency curve is shown on the associated graph for each gaging station (figures 11.1-11.272 in Appendix 2), and results presented in table 7 include only the default Bulletin 17B analysis. In other cases, however, the results could be improved by using various alternative procedures for frequency analysis. In these cases, the selected alternative frequency curve also is shown on the graph for each station, and results are included in table 7 . For each station in table 7 , the shaded row designates the selected alternative procedure, and a column with a heading of "Analytical procedure" indicates the type of procedure (or procedures) used in developing the selected alternative. These procedures are described in detail in the following sections.

\section{Procedures for Skew Coefficient and Low Outliers}

Bulletin 17B recommends the use of a skew coefficient that is based on the skew of the log-series of the systematic record (commonly termed the "station skew") weighted with a generalized, or regional, skew coefficient. The weighting is based on the length of the systematic record and the estimated standard error for the method used to determine the generalized skew coefficient. The generalized skew coefficient can be determined by using a nationwide generalized skew map presented in Bulletin 17B (plate 1) or by using methods based on data from long-term gaging stations in the area of interest as described in Bulletin 17B. Sando (1998) performed an analysis of generalized skew coefficients for South Dakota and determined that sufficient data were not available to improve generalized skew coefficients provided by the Bulletin 17B nationwide map. Sando (1998) also indicated that the small number of gaging stations that was available for development of the Bulletin 17B nationwide skew coefficient map probably was inadequate to accurately define generalized skew coefficients across the wide variety of hydrologic and physiographic conditions in South Dakota. In some cases, use of the standard weighted-skew procedures of Bulletin 17B resulted in frequency curves that fit poorly with long-term systematic records for a given station or were inconsistent with hydrologic patterns established from other long-term data sets. In some of these cases, improved results were obtained by using the station skew rather than the weighted skew. Selection of the station skew rather than the weighted skew generally was in accordance with guidance in Bulletin 17B relating to situations when the station skew deviates from the generalized skew by more than 0.5 .

The log-Pearson III distribution typically is most effective in fitting data that plot on log-probability scales as either straight lines or arcs that are uniformly either convex or concave. Many partial-record stations in South Dakota have been located along dry channels that seldom flow, and many gaged streams can be subject to low- or zero-flow conditions for extended periods. Log-probability plots of peak-flow series for stations that are strongly influenced by low- or zero-flow values frequently deviate from typical patterns, primarily in the lower end of the curve at smaller recurrence intervals. For stations with relatively long periods of record, these types of conditions tend to result in log-probability plots with varying degrees of sigmoid or S-shape curves. Fitting this type of pattern by using the log-Pearson III distribution is problematic and often results in a frequency curve that plots substantially above the systematic record data points at the upper end of the frequency curve (that is, higher recurrence intervals) and below the systematic record at the middle to lower end of the frequency curve. Thus, an unusually large number of lowlying data points can distort the fit of the frequency curve in the upper end where the data are more representative of substantial flood or near-flood events (Advisory Committee on Water Information, 2007).

Appropriate definition of the low-outlier threshold criterion provides a means of dealing with inappropriate influence of low-lying data points. The low-outlier threshold serves to censor low-lying data points so that they do not exert a large distorting influence on the fitted frequency curve (Advisory Committee on Water Information, 2007). However, the Bulletin 17B procedures do not ignore the censored low-lying data points, but rather incorporate their frequency of occurrence through the use of a conditional probability adjustment (U.S. Interagency Advisory Council on Water Data, 1982, Appen$\operatorname{dix} 5$ ).

The default Bulletin 17B procedures use the GrubbsBeck outlier test (Grubbs and Beck, 1972) to determine the low-outlier threshold on the basis of the mean and standard deviation of the log series of peak flows. An unusually large number of low-lying data points increases the standard deviation of the log series of peak flows, which makes it more difficult to trigger a significant low-outlier test result. When multiple values slightly exceed the Grubbs-Beck low-outlier threshold, Bulletin 17B permits the use of a user-defined low-outlier threshold to improve the fit of the frequency curve (U.S. Interagency Advisory Council on Water Data, 1982).

For some South Dakota stations, user-defined low-outlier thresholds were applied to adjust fits of the log-Pearson III distribution to systematic data. These adjustments reduced the influence of very small peak flows and focused the analysis on the part of the frequency curve (10- to 500-year recurrence intervals) that typically is of greatest importance for most peak-flow frequency applications.

The following example illustrates how adjustments to the default Bulletin 17B procedures for use of skew coefficients 
and low outliers were applied. Station 06477500 (map number 215) has a relatively long period of record (46 years; 1956-2001), and the peak-flow records at this long-term station provide the best available information on peak-flow characteristics. Figure 7 shows the systematic record for gaging station 06477500, which plots as an S-shaped curve on a log-probability scale. The uppermost frequency curve (shown as a solid grey line on figure 7) was derived by using default Bulletin 17B procedures for definition of the weighted skew and low-outlier threshold. The upper end of this frequency curve plots substantially above the systematic peak flows. The next lower curve (shown as a dashed black line) was derived by adjustment with a user-defined low-outlier threshold of $2 \mathrm{ft}^{3} / \mathrm{s}$ that truncated four peak flows from the lower end of the systematic record and eliminated the S-shaped effect that is problematic for the log-Pearson III distribution. The lowermost curve (shown as a solid black line) was derived by using the station skew and further improves the fit of the systematic record. The resulting curve substantially lowers the peak-flow frequency estimates for intermediate and large recurrence intervals. This curve is shown as the selected alternative curve in the graph for this station (fig. 11.215) that is provided in Appendix 2. Results of the selected alternative curve are believed to be reliable, on the basis of detailed examination of available systematic and historical data sets for this station and other hydrogically similar stations. Numerical values for the peak-flow frequency estimates for this curve and the default Bulletin 17B curve are shown in table 7, and information regarding distributional parameters is shown in table 9.

\section{Procedures for Gaging Stations Affected by Regulation}

Flows of many South Dakota streams are regulated to some extent by impoundments or diversions. In some cases, peak-flow characteristics largely are unaffected, especially where regulation consists of minor diversions for irrigation or water supply. However, effects are large for some streams that are regulated by large on-stream reservoirs or by substantial diversion to off-stream storage. The listing of annual peak flows (table 8) provides qualification codes for years of record with known potential for effects from regulation. A code of 6 indicates that a given peak probably was substantially affected by regulation, whereas a code of 5 indicates that the extent of influence from regulation is unknown. Stations with individual peak flows having a qualification code of 6 are noted in table 7 (analytical procedure "2"); however, stations having only

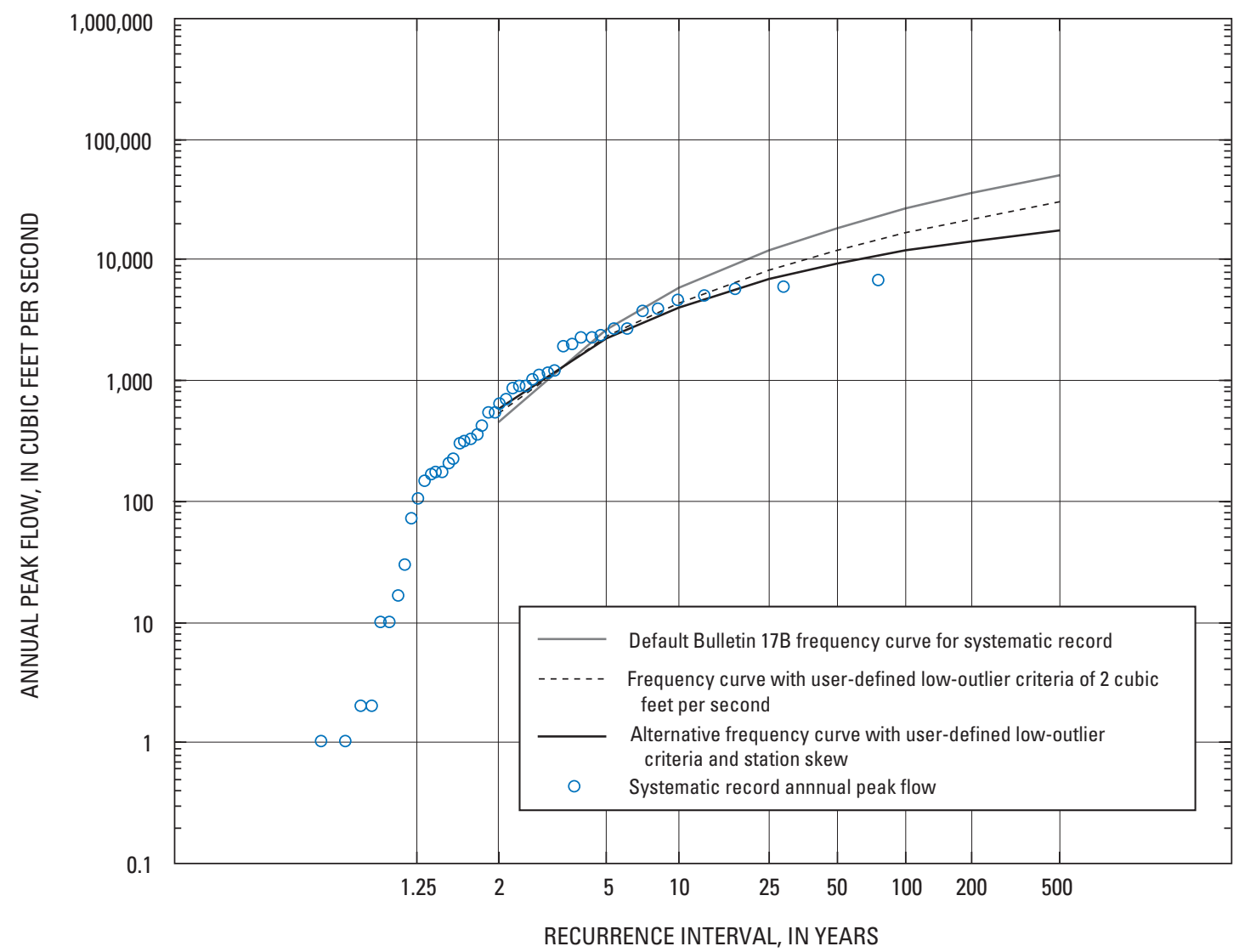

Figure 7. Peak-flow frequency information for Firesteel Creek near Mount Vernon (06477500) illustrating effects of low-outlier and skew adjustments on frequency curve fits. 
qualification codes of 5 generally are not footnoted. Examples include stations with minor effects from various types of diversions or stations located far enough from major reservoirs that effects are relatively small. No qualification codes were assigned for stations where influence from regulating structures is inconsequential relative to peak flows; however, absence of qualification coding does not imply absolute absence of regulating influence.

Table 1 presents selected information for major regulating structures (including both on-stream structures and major diversions to off-stream structures) that have potential to substantially affect peak-flow characteristics for gaging stations in South Dakota. The Missouri River has been highly regulated by a series of large reservoirs constructed during the 1950s, and flow characteristics largely are governed by reservoir operating criteria, which have varied substantially since the reservoirs were constructed. Thus, probability-based frequency estimates are not applicable for this system and are not provided for any stations along the main stem of the Missouri River. The effects of reservoir regulation also are substantial for various reaches of many other streams in the State; however, because variability in reservoir operating criteria generally is small, results of frequency analyses are presented for these stations, regardless of the degree of regulation at any given station.

For gaging stations with flow records substantially affected by regulation, peak-flow frequency analyses generally were restricted to periods of systematic or combined records after initiation of regulation. The primary exception is for some stations along the main-stem Cheyenne and Belle Fourche Rivers, which have been regulated by numerous structures that cause substantial uncertainty concerning the temporal stationarity of long-term peak-flow data. It was decided that the most representative peak-flow frequency estimates for regulated main-stem Cheyenne and Belle Fourche River stations would be obtained by using a consistent period of analysis (or base period; 1946-2001, 56 years) for all flow records. Most regulating structures in these basins were in operation during the selected base period. However, use of this base period resulted in inclusion of a few years of unregulated systematic record for a few gaging stations, located closely downstream from regulating structures. For these stations, detailed examination of the specific unregulated annual peak flows indicated that effects of reservoir operations probably would not have been substantial.

Procedures used for peak-flow frequency analyses for regulated periods generally are similar to those used for unregulated gaging stations. Table 1 lists stations for which periods of record were truncated owing to regulation. Peak flows for many other stations also are affected to at least some extent by the structures listed in table 1; however, available records often post-date effects of regulation. Such stations are noted in table 7 but are not listed in table 1.

Readers are cautioned that the frequency estimates for large recurrence intervals for stations regulated by reservoirs should not necessarily be considered reliable. Bulletin 17B provides a cautionary note that “... procedures do not cover watersheds where flood flows are appreciably altered by reservoir regulation or where the possibility of unusual events, such as dam failures, must be considered." For such stations, frequency estimates for small recurrence intervals are considered to be reliable; however, the frequency estimates for larger recurrence intervals are provided primarily for purposes of consistency, and should be used only with extreme caution. For many regulated streams, the potential effects of regulation diminish progressively in a downstream direction.

\section{Record-Extension Procedures}

The most commonly used alternative procedures involved several different methods for extension of systematic records. These procedures were effective for addressing bias resulting from nonrepresentative climatic conditions during several specific periods (figs. 3 and 4) and for reducing inconsistencies among multiple gaging stations along common stream channels with different periods of record.

Peak-flow records for eight stations were augmented by combining systematic records from one or more appropriate stations located in proximity along the same stream. These stations are noted in table 7, and selected information for the "secondary" stations used to augment peak-flow records is presented in table 2. Direct augmentation (that is, unadjusted combination) of records was performed for six stations in cases where differences in drainage areas were relatively small (generally less than about 5 percent) and differences in peakflow characteristics were considered negligible or minimal. Peak-flow frequency estimates are not presented in table 7 for the given secondary stations; however, estimates reported for the associated augmented station are considered applicable for the secondary stations. For two stations (06436180 and 06436760), missing records were extended by area-weighted interpolation of peak flows for stations upstream and downstream from the target station.

Record-extension procedures that adjust the logdistributional parameters for a target station, on the basis of correlation of concurrent records with one or more index stations, were used for some stations (table 3 ). These procedures were used only after reviewing peak-flow frequency estimates for consistency among multiple stations along the same channel or in relative proximity with similar hydrologic and geographic characteristics, as recommended in Bulletin 17B. Applications for western South Dakota generally were limited to cases where multiple stations with different periods of record had been operated along main stems of major river systems. Applications for eastern South Dakota were more extensive and sometimes included index stations located in nearby hydrologically similar drainage basins (table 3 ).

The primary procedure used for record extension was the two-station comparison procedure (Matalas and Jacobs, 1964) that is recommended in Bulletin 17B for adjusting the mean and standard deviation of the logs of the systematic data for a target station on the basis of correlation with concurrent 
Table 1. Description of regulating structures and diversions with potential to affect peak-flow characteristics for downstream gaging stations.

$\left[\mathrm{mi}^{2}\right.$; square miles; ND, not determined or unknown; E, estimated; NA, not applicable; $\mathrm{ft}^{3} / \mathrm{s}$, cubic feet per second]

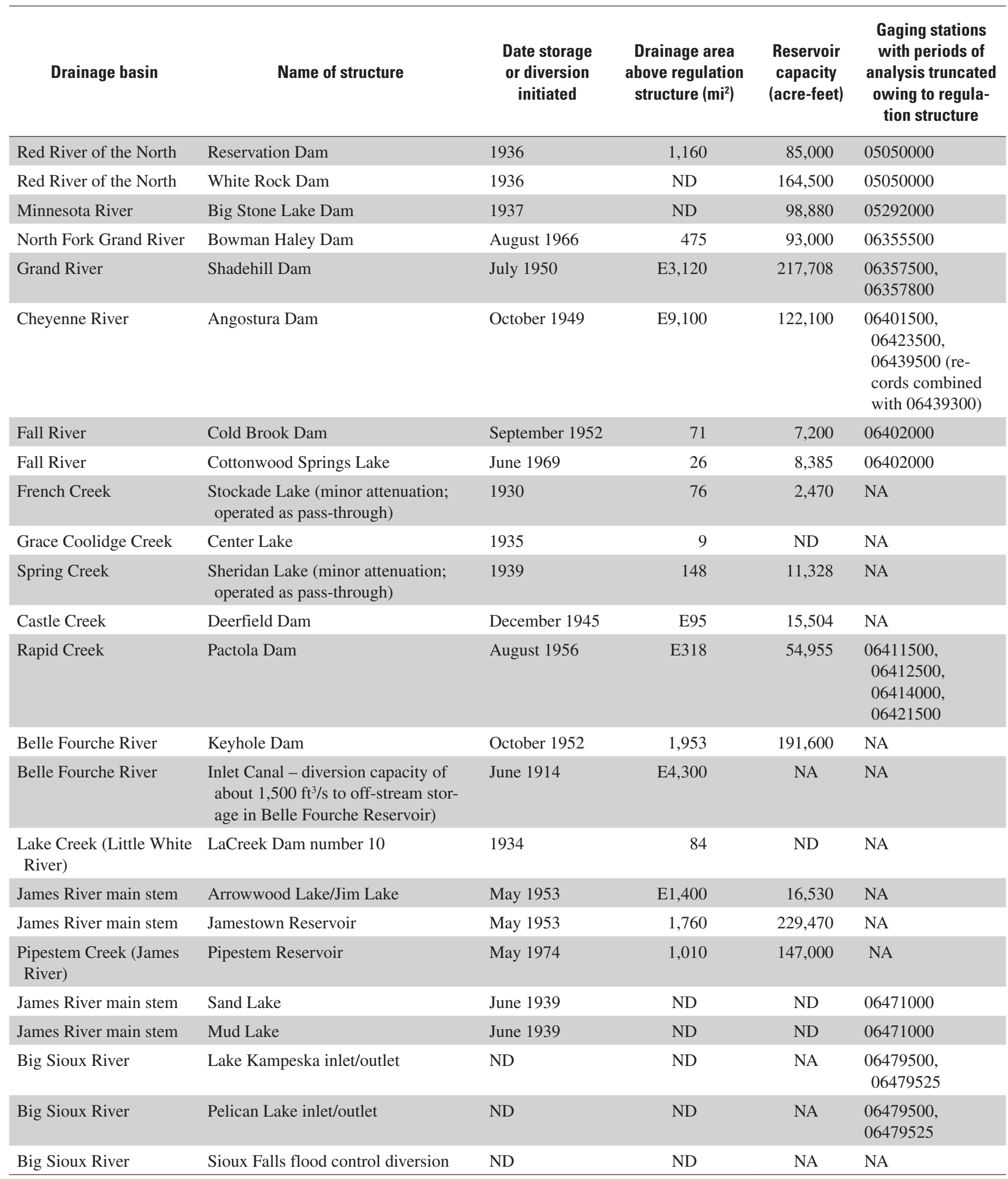


$\left[\mathrm{mi}^{2}\right.$, square miles]

\begin{tabular}{|c|c|c|c|c|c|c|c|c|c|c|c|c|c|c|c|}
\hline \multicolumn{6}{|c|}{ Primary gaging station } & \multicolumn{6}{|c|}{$\begin{array}{l}\text { Secondary gaging station(s) used to augment records of primary } \\
\text { gaging station }\end{array}$} & \multicolumn{4}{|c|}{ Combined characteristics } \\
\hline $\begin{array}{l}\text { Station } \\
\text { number }\end{array}$ & $\begin{array}{c}\text { Station } \\
\text { name }\end{array}$ & $\begin{array}{c}\text { Drainage } \\
\text { area } \\
\left(\mathrm{mi}^{2}\right)\end{array}$ & $\begin{array}{l}\text { Contri- } \\
\text { buting } \\
\text { drainage } \\
\text { area } \\
\left(\mathrm{mi}^{2}\right)\end{array}$ & $\begin{array}{l}\text { System- } \\
\text { atic } \\
\text { record } \\
\text { length } \\
\text { (years) }\end{array}$ & $\begin{array}{c}\text { Period of } \\
\text { systematic } \\
\text { record }\end{array}$ & $\begin{array}{l}\text { Station } \\
\text { number }\end{array}$ & $\begin{array}{c}\text { Station } \\
\text { name }\end{array}$ & $\begin{array}{c}\text { Drainage } \\
\text { area } \\
\left(\mathrm{mi}^{2}\right)\end{array}$ & $\begin{array}{l}\text { Contri- } \\
\text { buting } \\
\text { drainage } \\
\text { area } \\
\left(\mathrm{mi}^{2}\right)\end{array}$ & $\begin{array}{l}\text { System- } \\
\text { atic } \\
\text { record } \\
\text { length } \\
\text { (years) }\end{array}$ & $\begin{array}{l}\text { Period of } \\
\text { systemat- } \\
\text { ic record }\end{array}$ & $\begin{array}{l}\text { Augmen- } \\
\text { tation method }\end{array}$ & $\begin{array}{c}\text { Number } \\
\text { of years of } \\
\text { augmented } \\
\text { record } \\
\text { (years) }\end{array}$ & $\begin{array}{l}\text { Combined } \\
\text { analysis } \\
\text { record } \\
\text { length } \\
\text { (years) }\end{array}$ & $\begin{array}{l}\text { Combined } \\
\text { analysis } \\
\text { period }\end{array}$ \\
\hline 06357800 & $\begin{array}{l}\text { Grand River at } \\
\text { Little Eagle, } \\
\text { SD }\end{array}$ & 5,370 & 5,370 & 43 & $1959-2001$ & 06358000 & $\begin{array}{l}\text { Grand River } \\
\text { near Wakpala, } \\
\text { SD }\end{array}$ & 5,510 & 5,510 & 38 & $\begin{array}{l}1914-16 \\
1929 \\
1931-64\end{array}$ & Direct & $\begin{array}{c}8 \\
(1951-58)\end{array}$ & 51 & $1951-2001$ \\
\hline 06360500 & $\begin{array}{l}\text { Moreau River } \\
\text { near White- } \\
\text { horse, SD }\end{array}$ & 4,880 & 4,880 & 47 & 1955-2001 & 06361000 & $\begin{array}{l}\text { Moreau River } \\
\text { at Promise, } \\
\text { SD }\end{array}$ & 5,223 & 5,223 & 30 & 1929-58 & Direct & $\begin{array}{c}26 \\
(1929-54)\end{array}$ & 73 & 1929-2001 \\
\hline 06404998 & $\begin{array}{l}\text { Grace Coolidge } \\
\text { Creek near } \\
\text { Game Lodge } \\
\text { near Custer, } \\
\text { SD }\end{array}$ & 26.8 & 26.8 & 30 & 1972-2001 & 06405000 & $\begin{array}{l}\text { Grace Coolidge } \\
\text { Creek near } \\
\text { Custer, SD }\end{array}$ & 26.9 & 26.9 & 7 & $\begin{array}{r}1946-47, \\
1967-71\end{array}$ & Direct & $\begin{array}{c}7 \\
(1946-47 \\
1967-71)\end{array}$ & 37 & $\begin{array}{l}\text { 1946-47, } \\
1967-2001\end{array}$ \\
\hline \multirow[t]{2}{*}{06436180} & $\begin{array}{l}\text { Whitewood } \\
\text { Creek above } \\
\text { Whitewood, } \\
\text { SD }\end{array}$ & 56.3 & 56.3 & 19 & $1983-2001$ & 06436170 & $\begin{array}{l}\text { Whitewood } \\
\text { Creek at } \\
\text { Deadwood, } \\
\text { SD }\end{array}$ & 40.6 & 40.6 & 14 & $1982-95$ & \multirow{2}{*}{$\begin{array}{l}\text { Area-weighted } \\
\text { interpolation } \\
\text { between sta- } \\
\text { tions on same } \\
\text { channel }\end{array}$} & $\begin{array}{c}1 \\
(1982)\end{array}$ & 20 & 1982-2001 \\
\hline & & & & & & 06436190 & $\begin{array}{l}\text { Whitewood } \\
\text { Creek near } \\
\text { Whitewood, } \\
\text { SD }\end{array}$ & 77.4 & 77.4 & 20 & 1982-2001 & & $\begin{array}{c}1 \\
(1982)\end{array}$ & 20 & $1982-2001$ \\
\hline \multirow[t]{2}{*}{06436760} & $\begin{array}{l}\text { Horse Creek } \\
\text { above Vale, } \\
\text { SD }\end{array}$ & 464 & 464 & 21 & $1981-2001$ & 06436700 & $\begin{array}{l}\text { Indian Creek } \\
\text { near Arpan, } \\
\text { SD }\end{array}$ & 315 & 315 & 20 & $1962-81$ & \multirow{2}{*}{$\begin{array}{l}\text { Area-weighted } \\
\text { interpolation } \\
\text { between sta- } \\
\text { tions on same } \\
\text { channel }\end{array}$} & $\begin{array}{c}19 \\
(1962-81)\end{array}$ & 40 & 1962-2001 \\
\hline & & & & & & 06436800 & $\begin{array}{l}\text { Horse Creek } \\
\text { near Vale, SD }\end{array}$ & 530 & 530 & 19 & $1962-80$ & & $\begin{array}{c}19 \\
(1962-81)\end{array}$ & 40 & 1962-2001 \\
\hline 06439300 & $\begin{array}{l}\text { Cheyenne River } \\
\text { at Cherry } \\
\text { Creek, SD }\end{array}$ & 23,900 & 23,900 & 34 & 1961-94 & 06439500 & $\begin{array}{l}\text { Cheyenne } \\
\text { River near } \\
\text { Eagle Butte, } \\
\text { SD }\end{array}$ & 24,500 & 24,500 & 39 & 1929-67 & Direct & $\begin{array}{c}15 \\
(1946-60)\end{array}$ & 66 & ${ }^{1} 1946-2001$ \\
\hline 06445685 & $\begin{array}{l}\text { White } \\
\text { River near } \\
\text { Nebraska/ } \\
\text { South Dakota } \\
\text { State line }\end{array}$ & 1,440 & 1,440 & 14 & 1988-2001 & 06445700 & $\begin{array}{l}\text { White River at } \\
\text { Slim Butte, } \\
\text { SD }\end{array}$ & 1,500 & 1,500 & 19 & $\begin{array}{r}\text { 1962-73, } \\
1991-97\end{array}$ & Direct & $\begin{array}{c}12 \\
(1962-73)\end{array}$ & 26 & $\begin{array}{l}\text { 1962-73, } \\
1988-2001\end{array}$ \\
\hline \multirow[t]{2}{*}{06482020} & \multirow{2}{*}{$\begin{array}{l}\text { Big Sioux } \\
\text { River at North } \\
\text { Cliff Avenue } \\
\text { at Sioux Falls, } \\
\text { SD }\end{array}$} & \multirow[t]{2}{*}{5,216} & \multirow[t]{2}{*}{3,729} & \multirow[t]{2}{*}{31} & \multirow[t]{2}{*}{$\begin{array}{l}1969, \\
1972-2001\end{array}$} & 06482000 & $\begin{array}{l}\text { Big Sioux } \\
\text { River at Sioux } \\
\text { Falls, SD }\end{array}$ & 5,197 & 3,710 & 53 & 1944-60 & Direct & $\begin{array}{c}16 \\
(1944-59)\end{array}$ & 58 & \multirow[t]{2}{*}{ 1944-2001 } \\
\hline & & & & & & 06482100 & $\begin{array}{l}\text { Big Sioux } \\
\text { River near } \\
\text { Brandon, SD }\end{array}$ & 5,261 & 3,774 & 58 & 1960-72 & Direct & $\begin{array}{c}11 \\
(1960-68, \\
1970-71)\end{array}$ & & \\
\hline
\end{tabular}


Table 3. Selected information regarding station comparisons used in extension of records.

$\left[\mathrm{mi}^{2}\right.$, square miles; 17B, Bulletin 17B two-station analysis (U.S. Interagency Advisory Council on Water Data, 1982); MIX, mixed-station procedure based on maintenance of variance type I analysis (Alley and Burns, 1983)]

\begin{tabular}{|c|c|c|c|c|c|c|c|c|c|c|c|c|c|c|}
\hline \multicolumn{6}{|c|}{ Target station for which record-extension procedures were used } & \multicolumn{6}{|c|}{ Index station(s) used in record-extension procedures } & \multirow[b]{2}{*}{$\begin{array}{c}\text { Years of } \\
\text { concurrent } \\
\text { record }\end{array}$} & \multirow[b]{2}{*}{$\begin{array}{l}\text { Pearson } \\
\text { correlation } \\
\text { coefficient } \\
\text { for logs }\end{array}$} & \multirow[b]{2}{*}{$\begin{array}{c}\text { Record } \\
\text { extension } \\
\text { method }\end{array}$} \\
\hline $\begin{array}{l}\text { Station } \\
\text { number }\end{array}$ & Station name & $\begin{array}{c}\text { Drainage } \\
\text { area } \\
\left(\mathrm{mi}^{2}\right)\end{array}$ & $\begin{array}{c}\text { Contributing } \\
\text { drainage } \\
\text { area } \\
\left(\mathrm{mi}^{2}\right) \\
\end{array}$ & $\begin{array}{c}\text { Systematic } \\
\text { record } \\
\text { length } \\
\text { (years) }\end{array}$ & $\begin{array}{l}\text { Period of } \\
\text { systematic } \\
\text { record }\end{array}$ & $\begin{array}{l}\text { Station } \\
\text { number }\end{array}$ & Station name & $\begin{array}{l}\text { Drainage } \\
\text { area }\left(\mathrm{mi}^{2}\right)\end{array}$ & $\begin{array}{l}\text { Contributing } \\
\text { drainage } \\
\text { area }\left(\mathrm{mi}^{2}\right)\end{array}$ & $\begin{array}{l}\text { System- } \\
\text { atic record } \\
\text { length } \\
\text { (years) }\end{array}$ & $\begin{array}{l}\text { Period of } \\
\text { systematic } \\
\text { record }\end{array}$ & & & \\
\hline 05051650 & $\begin{array}{l}\text { La Belle Creek } \\
\text { near Veblen, } \\
\text { SD }\end{array}$ & 8.74 & 8.74 & 14 & 1988-2001 & 06479438 & $\begin{array}{l}\text { Big Sioux } \\
\text { River near } \\
\text { Watertown, } \\
\text { SD }\end{array}$ & 1,007 & 228 & 29 & 1973-2001 & 14 & 0.71 & 17B \\
\hline 05289950 & $\begin{array}{l}\text { Little Min- } \\
\text { nesota River } \\
\text { tributary at } \\
\text { Sisseton, SD }\end{array}$ & 4.21 & 4.21 & 10 & 1970-79 & 05292000 & $\begin{array}{l}\text { Minnesota } \\
\text { River at Or- } \\
\text { tonville, MN }\end{array}$ & 1,160 & 1,160 & 64 & $1938-2001$ & 10 & .85 & 17B \\
\hline 05289985 & $\begin{array}{l}\text { Big Coulee } \\
\text { Creek near } \\
\text { Peever, SD }\end{array}$ & 12.1 & 12.1 & 14 & 1988-2001 & 06479438 & $\begin{array}{l}\text { Big Sioux } \\
\text { River near } \\
\text { Watertown, } \\
\text { SD }\end{array}$ & 1,007 & 228 & 29 & 1973-2001 & 14 & .77 & 17B \\
\hline 05290300 & $\begin{array}{l}\text { North Fork } \\
\text { Whetstone } \\
\text { River } \\
\text { tributary near } \\
\text { Wilmot, SD }\end{array}$ & .96 & .96 & 10 & 1970-79 & 06480000 & $\begin{array}{l}\text { Big Sioux } \\
\text { River near } \\
\text { Brookings, } \\
\text { SD }\end{array}$ & 3,898 & 2,419 & 48 & 1954-2001 & 10 & .78 & 17B \\
\hline 05292600 & $\begin{array}{l}\text { North Fork } \\
\text { Yellow } \\
\text { Bank River } \\
\text { tributary near } \\
\text { Stockholm, } \\
\text { SD }\end{array}$ & 8.15 & 8.15 & 10 & 1970-79 & 06479950 & $\begin{array}{l}\text { Deer Creek } \\
\text { near Brook- } \\
\text { ings, SD }\end{array}$ & 4.04 & 4.04 & 25 & $1956-80$ & 10 & .65 & 17B \\
\hline 05292704 & $\begin{array}{l}\text { North Fork } \\
\text { Yellow Bank } \\
\text { River near } \\
\text { Odessa, MN }\end{array}$ & 208 & 208 & 11 & 1991-2001 & 05291000 & $\begin{array}{l}\text { Whetstone } \\
\text { River near } \\
\text { Big Stone } \\
\text { City, SD }\end{array}$ & 398 & 398 & 74 & $\begin{array}{l}\text { 1910-12, } \\
1931-2001\end{array}$ & 11 & .87 & 17B \\
\hline 05299700 & $\begin{array}{l}\text { Cobb Creek } \\
\text { near Gary, } \\
\text { SD }\end{array}$ & 70.3 & 69.4 & 10 & 1992-2001 & 06479438 & $\begin{array}{l}\text { Big Sioux } \\
\text { River near } \\
\text { Watertown, } \\
\text { SD }\end{array}$ & 1,007 & 228 & 29 & 1973-2001 & 10 & .84 & 17B \\
\hline 06359000 & $\begin{array}{l}\text { Moreau River } \\
\text { at Bixby, SD }\end{array}$ & 1,570 & 1,570 & 25 & 1949-73 & $\begin{array}{l}\text { 06360500/ } \\
06361000 \\
\text { combined } \\
\text { records }\end{array}$ & $\begin{array}{l}\text { Moreau River } \\
\text { near White- } \\
\text { horse, SD/ } \\
\text { Moreau River } \\
\text { near Promise, } \\
\text { SD (combined } \\
\text { records) }\end{array}$ & $\begin{array}{l}4,880 / \\
5,223\end{array}$ & $\begin{array}{l}4,880 / \\
5,223\end{array}$ & 73 & 1929-2001 & 25 & .63 & 17B \\
\hline
\end{tabular}


Table 3. Selected information regarding station comparisons used in extension of records.-Continued

[mi² , square miles; 17B, Bulletin 17B two-station analysis (U.S. Interagency Advisory Council on Water Data, 1982); MIX, mixed-station procedure based on maintenance of variance type I analysis (Alley and Burns, 1983)]

\begin{tabular}{|c|c|c|c|c|c|c|c|c|c|c|c|c|c|c|}
\hline \multicolumn{6}{|c|}{ Target station for which record-extension procedures were used } & \multicolumn{6}{|c|}{ Index station(s) used in record-extension procedures } & \multirow[b]{2}{*}{$\begin{array}{c}\text { Years of } \\
\text { concurrent } \\
\text { record }\end{array}$} & \multirow[b]{2}{*}{$\begin{array}{l}\text { Pearson } \\
\text { correlation } \\
\text { coefficient } \\
\text { for logs }\end{array}$} & \multirow[b]{2}{*}{$\begin{array}{c}\text { Record } \\
\text { extension } \\
\text { method }\end{array}$} \\
\hline $\begin{array}{l}\text { Station } \\
\text { number }\end{array}$ & Station name & $\begin{array}{l}\text { Drainage } \\
\text { area } \\
\left(\mathrm{mi}^{2}\right)\end{array}$ & $\begin{array}{c}\text { Contributing } \\
\text { drainage } \\
\text { area } \\
\left(\mathrm{mi}^{2}\right) \\
\end{array}$ & $\begin{array}{c}\text { Systematic } \\
\text { record } \\
\text { length } \\
\text { (years) } \\
\end{array}$ & $\begin{array}{l}\text { Period of } \\
\text { systematic } \\
\text { record }\end{array}$ & $\begin{array}{l}\text { Station } \\
\text { number }\end{array}$ & Station name & $\begin{array}{l}\text { Drainage } \\
\text { area }\left(\mathrm{mi}^{2}\right)\end{array}$ & $\begin{array}{l}\text { Contributing } \\
\text { drainage } \\
\text { area }\left(\mathbf{m i}^{2}\right)\end{array}$ & $\begin{array}{l}\text { System- } \\
\text { atic record } \\
\text { length } \\
\text { (years) }\end{array}$ & $\begin{array}{l}\text { Period of } \\
\text { systematic } \\
\text { record }\end{array}$ & & & \\
\hline 06359500 & $\begin{array}{l}\text { Moreau River } \\
\text { near Faith, } \\
\text { SD }\end{array}$ & 2,660 & 2,660 & 58 & 1944-2001 & $\begin{array}{l}06360500 / \\
06361000 \\
\text { combined } \\
\text { records }\end{array}$ & $\begin{array}{l}\text { Moreau River } \\
\text { near White- } \\
\text { horse, SD/ } \\
\text { Moreau River } \\
\text { near Promise, } \\
\text { SD (combined } \\
\text { records) }\end{array}$ & $\begin{array}{l}4,880 / \\
5,223\end{array}$ & $\begin{array}{l}4,880 / \\
5,223\end{array}$ & 73 & $1929-2001$ & 58 & .79 & 17B \\
\hline 06360000 & $\begin{array}{l}\text { Moreau River } \\
\text { near Eagle } \\
\text { Butte, SD }\end{array}$ & 4,320 & 4,320 & 15 & $1944-58$ & $\begin{array}{l}06360500 / \\
06361000 \\
\text { combined } \\
\text { records }\end{array}$ & $\begin{array}{l}\text { Moreau River } \\
\text { near White- } \\
\text { horse, SD/ } \\
\text { Moreau River } \\
\text { near Promise, } \\
\text { SD (combined } \\
\text { records) }\end{array}$ & $\begin{array}{l}4,880 / \\
5,223\end{array}$ & $\begin{array}{l}4,880 / \\
5,223\end{array}$ & 73 & 1929-2001 & 15 & 0.94 & 17B \\
\hline 06361020 & $\begin{array}{l}\text { Swan Lake } \\
\text { tributary near } \\
\text { Bowdle, SD }\end{array}$ & 27.1 & 27.1 & 10 & 1970-79 & 06354860 & $\begin{array}{l}\text { Spring Creek } \\
\text { near Herreid, } \\
\text { SD }\end{array}$ & 440 & 220 & 34 & $\begin{array}{c}\text { 1963-87, } \\
1989-97\end{array}$ & 10 & .77 & 17B \\
\hline 06400500 & $\begin{array}{l}\text { Cheyenne } \\
\text { River near } \\
\text { Hot Springs, } \\
\text { SD }\end{array}$ & 8,710 & 8,710 & 36 & $\begin{array}{c}\text { 1915-20, } \\
1943-72\end{array}$ & 06395000 & $\begin{array}{l}\text { Cheyenne } \\
\text { River at Edge- } \\
\text { mont, SD }\end{array}$ & 7,143 & 7,143 & 60 & $\begin{array}{l}\text { 1905, } \\
\text { 1929-32, } \\
1947-2001\end{array}$ & 26 & .86 & 17B \\
\hline 06402995 & $\begin{array}{l}\text { French Creek } \\
\text { above Stock- } \\
\text { ade Lake near } \\
\text { Custer, SD }\end{array}$ & 68.7 & 68.7 & 11 & 1991-2001 & 06403300 & $\begin{array}{l}\text { French Creek } \\
\text { above Fair- } \\
\text { burn, SD }\end{array}$ & 105 & 105 & 20 & $1982-2001$ & 11 & .80 & 17B \\
\hline 06406500 & $\begin{array}{l}\text { Battle Creek } \\
\text { below Her- } \\
\text { mosa, SD }\end{array}$ & 285 & 285 & 13 & 1989-2001 & 06406000 & $\begin{array}{c}\text { Battle Creek at } \\
\text { Hermosa, SD }\end{array}$ & 178 & 178 & 51 & $\begin{array}{l}\text { 1950-71, } \\
1973-2001\end{array}$ & 13 & .85 & 17B \\
\hline 06436198 & $\begin{array}{l}\text { Whitewood } \\
\text { Creek above } \\
\text { Vale, SD }\end{array}$ & 102 & 102 & 19 & 1983-2001 & 06436190 & $\begin{array}{l}\text { Whitewood } \\
\text { Creek near } \\
\text { Whitewood, } \\
\text { SD }\end{array}$ & 77.4 & 77.4 & 20 & $1982-2001$ & 19 & .89 & MIX \\
\hline 06436800 & $\begin{array}{l}\text { Horse Creek } \\
\text { near Vale, SD }\end{array}$ & 530 & 530 & 19 & 1962-1980 & 06436760 & $\begin{array}{l}\text { Horse Creek } \\
\text { above Vale, } \\
\text { SD }\end{array}$ & 464 & 464 & 19 & 1962-80 & 19 & .96 & MIX \\
\hline
\end{tabular}


Table 3. Selected information regarding station comparisons used in extension of records.-Continued

$\left[\mathrm{mi}^{2}\right.$, square miles; 17B, Bulletin 17B two-station analysis (U.S. Interagency Advisory Council on Water Data, 1982); MIX, mixed-station procedure based on maintenance of variance type I analysis (Alley and Burns, 1983)]

\begin{tabular}{|c|c|c|c|c|c|c|c|c|c|c|c|c|c|c|}
\hline \multicolumn{6}{|c|}{ Target station for which record-extension procedures were used } & \multicolumn{6}{|c|}{ Index station(s) used in record-extension procedures } & \multirow[b]{2}{*}{$\begin{array}{l}\text { Years of } \\
\text { concurrent } \\
\text { record }\end{array}$} & \multirow[b]{2}{*}{$\begin{array}{l}\text { Pearson } \\
\text { correlation } \\
\text { coefficient } \\
\text { for logs }\end{array}$} & \multirow[b]{2}{*}{$\begin{array}{c}\text { Record } \\
\text { extension } \\
\text { method }\end{array}$} \\
\hline $\begin{array}{l}\text { Station } \\
\text { number }\end{array}$ & Station name & $\begin{array}{c}\text { Drainage } \\
\text { area } \\
\left(\mathrm{mi}^{2}\right)\end{array}$ & $\begin{array}{c}\text { Contributing } \\
\text { drainage } \\
\text { area } \\
\left(\mathrm{mi}^{2}\right)\end{array}$ & $\begin{array}{l}\text { Systematic } \\
\text { record } \\
\text { length } \\
\text { (years) }\end{array}$ & $\begin{array}{l}\text { Period of } \\
\text { systematic } \\
\text { record }\end{array}$ & $\begin{array}{l}\text { Station } \\
\text { number }\end{array}$ & Station name & $\begin{array}{l}\text { Drainage } \\
\text { area }\left(\mathrm{mi}^{2}\right)\end{array}$ & $\begin{array}{l}\text { Contributing } \\
\text { drainage } \\
\text { area }\left(\mathrm{mi}^{2}\right)\end{array}$ & $\begin{array}{l}\text { System- } \\
\text { atic record } \\
\text { length } \\
\text { (years) }\end{array}$ & $\begin{array}{l}\text { Period of } \\
\text { systematic } \\
\text { record }\end{array}$ & & & \\
\hline 06438500 & $\begin{array}{l}\text { Cheyenne } \\
\text { River near } \\
\text { Plainview, } \\
\text { SD }\end{array}$ & 21,640 & 21,640 & 38 & $\begin{array}{l}\text { 1951-81, } \\
\text { 1995-2001 }\end{array}$ & $\begin{array}{l}\text { 06439300/ } \\
06439500 \\
\text { combined } \\
\text { records }\end{array}$ & $\begin{array}{l}\text { Cheyenne } \\
\text { River at } \\
\text { Cherry Creek, } \\
\text { SD/ Cheyenne } \\
\text { River near } \\
\text { Eagle Butte, } \\
\text { SD }\end{array}$ & $\begin{array}{l}23,900 / \\
24,500\end{array}$ & $\begin{array}{l}23,900 / \\
24,500\end{array}$ & 66 & 1929-94 & 31 & .91 & MIX \\
\hline $\begin{array}{l}06439300 / \\
06439500 \\
\text { combined } \\
\text { records }\end{array}$ & $\begin{array}{l}\text { Cheyenne Riv- } \\
\text { er at Cherry } \\
\text { Creek, SD/ } \\
\text { Cheyenne } \\
\text { River near } \\
\text { Eagle Butte, } \\
\text { SD }\end{array}$ & $\begin{array}{l}23,900 / \\
24,500\end{array}$ & $\begin{array}{l}23,900 / \\
24,500\end{array}$ & 66 & 1929-94 & 06438500 & $\begin{array}{l}\text { Cheyenne } \\
\text { River at Plain- } \\
\text { view, SD }\end{array}$ & 21,640 & 21,640 & 38 & $\begin{array}{l}\text { 1951-81, } \\
1995-2001\end{array}$ & 31 & .91 & MIX \\
\hline 06440200 & $\begin{array}{l}\text { South Fork } \\
\text { Bad River } \\
\text { near Cotton- } \\
\text { wood, SD }\end{array}$ & 250 & 250 & 13 & 1989-2001 & 6441000 & $\begin{array}{l}\text { Bad River near } \\
\text { Midland, SD }\end{array}$ & 1,460 & 1,460 & 56 & 1946-2001 & 13 & 0.75 & 17B \\
\hline 06449300 & $\begin{array}{l}\text { Little White } \\
\text { River above } \\
\text { Rosebud, SD }\end{array}$ & 890 & 630 & 18 & 1982-99 & 06449500 & $\begin{array}{l}\text { Little White } \\
\text { River near } \\
\text { Rosebud, SD }\end{array}$ & 1,020 & 760 & 58 & 1944-2001 & 18 & .84 & 17B \\
\hline 06452320 & $\begin{array}{l}\text { Platte Creek } \\
\text { near Platte, } \\
\text { SD }\end{array}$ & 741 & 741 & 13 & 1989-2001 & 06477150 & $\begin{array}{l}\text { Rock Creek } \\
\text { near Fulton, } \\
\text { SD }\end{array}$ & 240 & 240 & 26 & $\begin{array}{l}\text { 1967-79, } \\
\text { 1989-2001 }\end{array}$ & 13 & .82 & 17B \\
\hline 06453250 & $\begin{array}{c}\text { Choteau Creek } \\
\text { tributary near } \\
\text { Wagner, SD }\end{array}$ & 15.6 & 15.6 & 10 & 1970-79 & 06464500 & $\begin{array}{l}\text { Keya Paha } \\
\text { River at } \\
\text { Wewela, SD }\end{array}$ & 1,070 & 1,070 & 54 & $\begin{array}{l}\text { 1939-40, } \\
1950-2001\end{array}$ & 10 & .83 & 17B \\
\hline 06453255 & $\begin{array}{l}\text { Choteau Creek } \\
\text { near Avon, } \\
\text { SD }\end{array}$ & 602 & 602 & 19 & 1983-2001 & 06478690 & $\begin{array}{l}\text { West Fork } \\
\text { Vermillion } \\
\text { River near } \\
\text { Parker, SD }\end{array}$ & 377 & 377 & 40 & 1962-2001 & 19 & .73 & 17B \\
\hline 06471350 & $\begin{array}{l}\text { Maple River } \\
\text { at Frederick, } \\
\text { SD }\end{array}$ & 755 & 423 & 14 & $1956-69$ & 06471200 & $\begin{array}{l}\text { Maple River at } \\
\text { North Dakota- } \\
\text { South Dakota } \\
\text { State line }\end{array}$ & 716 & 384 & 45 & 1957-2001 & 13 & 1.00 & MIX \\
\hline \multirow[t]{2}{*}{06472000} & \multirow{2}{*}{$\begin{array}{l}\text { James River } \\
\text { near Strat- } \\
\text { ford, SD }\end{array}$} & \multirow[t]{2}{*}{8,865} & \multirow[t]{2}{*}{4,861} & \multirow[t]{2}{*}{26} & \multirow{2}{*}{$\begin{array}{l}1950-72, \\
1977, \\
1997,2001\end{array}$} & 06473000 & $\begin{array}{c}\text { James River at } \\
\text { Ashton, SD }\end{array}$ & 9,742 & 5,673 & 56 & 1946-2001 & 26 & 1.00 & \multirow[t]{2}{*}{ MIX } \\
\hline & & & & & & 06476000 & $\begin{array}{l}\text { James River at } \\
\text { Huron, SD }\end{array}$ & 15,869 & 11,721 & 62 & $\begin{array}{l}\text { 1929-32, } \\
1944-2001\end{array}$ & 26 & .80 & \\
\hline
\end{tabular}


Table 3. Selected information regarding station comparisons used in extension of records. - Continued

[mi², square miles; 17B, Bulletin 17B two-station analysis (U.S. Interagency Advisory Council on Water Data, 1982); MIX, mixed-station procedure based on maintenance of variance type I analysis (Alley and Burns, 1983)]

\begin{tabular}{|c|c|c|c|c|c|c|c|c|c|c|c|c|c|c|}
\hline \multicolumn{6}{|c|}{ Target station for which record-extension procedures were used } & \multicolumn{6}{|c|}{ Index station(s) used in record-extension procedures } & \multirow[b]{2}{*}{$\begin{array}{l}\text { Years of } \\
\text { concurrent } \\
\text { record }\end{array}$} & \multirow[b]{2}{*}{$\begin{array}{l}\text { Pearson } \\
\text { correlation } \\
\text { coefficient } \\
\text { for logs }\end{array}$} & \multirow[b]{2}{*}{$\begin{array}{c}\text { Record } \\
\text { extension } \\
\text { method }\end{array}$} \\
\hline $\begin{array}{l}\text { Station } \\
\text { number }\end{array}$ & Station name & $\begin{array}{c}\text { Drainage } \\
\text { area } \\
\left(\mathrm{mi}^{2}\right)\end{array}$ & $\begin{array}{c}\text { Contributing } \\
\text { drainage } \\
\text { area } \\
\left(\mathrm{mi}^{2}\right)\end{array}$ & $\begin{array}{c}\text { Systematic } \\
\text { record } \\
\text { length } \\
\text { (years) }\end{array}$ & $\begin{array}{l}\text { Period of } \\
\text { systematic } \\
\text { record }\end{array}$ & $\begin{array}{l}\text { Station } \\
\text { number }\end{array}$ & Station name & $\begin{array}{l}\text { Drainage } \\
\text { area }\left(\mathrm{mi}^{2}\right)\end{array}$ & $\begin{array}{c}\text { Contributing } \\
\text { drainage } \\
\text { area }\left(\mathrm{mi}^{2}\right)\end{array}$ & $\begin{array}{l}\text { System- } \\
\text { atic record } \\
\text { length } \\
\text { (years) }\end{array}$ & $\begin{array}{l}\text { Period of } \\
\text { systematic } \\
\text { record }\end{array}$ & & & \\
\hline 06474000 & $\begin{array}{l}\text { Turtle Creek } \\
\text { near Tulare, } \\
\text { SD }\end{array}$ & 1,124 & 1,124 & 36 & $\begin{array}{l}1954-56, \\
1966-81, \\
1985-2001\end{array}$ & 06474500 & $\begin{array}{l}\text { Turtle Creek at } \\
\text { Redfield, SD }\end{array}$ & 1,481 & 1,481 & 28 & $\begin{array}{l}1946-72, \\
1997\end{array}$ & 11 & .94 & MIX \\
\hline 06474500 & $\begin{array}{c}\text { Turtle Creek at } \\
\text { Redfield, SD }\end{array}$ & 1,481 & 1,481 & 28 & $\begin{array}{l}1946-72 \\
1997\end{array}$ & 06474000 & $\begin{array}{l}\text { Turtle Creek } \\
\text { near Tulare, } \\
\text { SD }\end{array}$ & 1,124 & 1,124 & 36 & $\begin{array}{l}\text { 1954-56, } \\
\text { 1966-81, } \\
\text { 1985-2001 }\end{array}$ & 11 & .94 & MIX \\
\hline \multirow[t]{2}{*}{06478000} & $\begin{array}{l}\text { James River } \\
\text { near Mitchell, } \\
\text { SD }\end{array}$ & 19,064 & 14,916 & 14 & $\begin{array}{l}\text { 1954-58, } \\
1966-72 \\
1995,1997\end{array}$ & 06477000 & $\begin{array}{l}\text { James River } \\
\text { near Forest- } \\
\text { burg, SD }\end{array}$ & 17,590 & 13,442 & 52 & $1950-2001$ & 26 & .98 & MIX \\
\hline & & & & & & 06478500 & $\begin{array}{l}\text { James River } \\
\text { near Scotland, } \\
\text { SD }\end{array}$ & 20,653 & 16,505 & 73 & 1929-2001 & 26 & .96 & \\
\hline 06479010 & $\begin{array}{l}\text { Vermillion } \\
\text { River near } \\
\text { Vermillion, } \\
\text { SD }\end{array}$ & 2,302 & 1,808 & 18 & 1984-2001 & 06479000 & $\begin{array}{l}\text { Vermillion } \\
\text { River near } \\
\text { Wakonda, SD }\end{array}$ & 2,170 & 1,676 & 56 & 1946-2001 & 18 & .97 & 17B \\
\hline 06479215 & $\begin{array}{l}\text { Big Sioux } \\
\text { River near } \\
\text { Florence, SD }\end{array}$ & 638 & 67.9 & 18 & 1984-2001 & 06480000 & $\begin{array}{l}\text { Big Sioux } \\
\text { River near } \\
\text { Brookings, } \\
\text { SD }\end{array}$ & 3,898 & 2,419 & 48 & 1954-2001 & 18 & 0.72 & 17B \\
\hline 06479500 & $\begin{array}{l}\text { Big Sioux } \\
\text { River at Wa- } \\
\text { tertown, SD }\end{array}$ & 1,129 & 350 & 30 & $\begin{array}{l}\text { 1946-72, } \\
1997, \\
2000-2001\end{array}$ & 06480000 & $\begin{array}{l}\text { Big Sioux } \\
\text { River near } \\
\text { Brookings }\end{array}$ & 3,898 & 2,419 & 48 & 1954-2001 & 22 & .78 & 17B \\
\hline 06479910 & $\begin{array}{l}\text { Sixmile Creek } \\
\text { near Brook- } \\
\text { ings, SD }\end{array}$ & 54 & 54 & 10 & 1971-80 & 06480000 & $\begin{array}{l}\text { Big Sioux } \\
\text { River near } \\
\text { Brookings }\end{array}$ & 3,898 & 2,419 & 48 & 1954-2001 & 10 & .83 & 17B \\
\hline 06479928 & $\begin{array}{l}\text { Battle Creek } \\
\text { near Nunda, } \\
\text { SD }\end{array}$ & 163 & 158.2 & 10 & 1988-97 & 06480000 & $\begin{array}{l}\text { Big Sioux } \\
\text { River near } \\
\text { Brookings }\end{array}$ & 3,898 & 2,419 & 48 & 1954-2001 & 10 & .90 & 17B \\
\hline
\end{tabular}


records from a nearby index station. This procedure was used for record extension for 24 stations (table 3). The number of concurrent years of record between the target and index stations ranged from 10 to 58 (median of 13), and correlation coefficients ranged from 0.63 to 0.97 (median of 0.82). In all cases, the criteria were met for determining acceptable results for using the two-station comparison, as specified in Bulletin 17B. Although the two-station procedure effectively adjusts the mean and standard deviation of the log series, an appropriate skew must be determined to complete the frequency analysis. Bulletin 17B recommends use of the weighted skew of the systematic record for the target station. However, more reasonable peak-flow frequency estimates were obtained in several cases by using either the station skew or generalized skew, on the basis of investigation of nearby long-term hydrologically similar gaging stations. Generally, selection of the station or generalized skew rather than the weighted skew corresponded with guidance in Bulletin 17B relating to situations when the station skew deviates from the generalized skew by more than 0.5 .

In some cases, a "mixed-station procedure" was used as an alternative method for adjusting the magnitude/frequency relations of the target station to be more representative of a longer period (table 3 ). This mixed-station procedure is based on the use of multiple potential index stations and the use of a maintenance of variance type I (MOVE.1) straight-line fitting procedure rather than an ordinary least squares straightline fitting procedure (Alley and Burns, 1983). The MOVE.1 procedure, though analogous to ordinary least squares regression, results in an extended peak-flow record with a variance comparable to that of the unextended peak-flow record (Cary and Parrett, 1996). The use of multiple potential index stations allows additional important peak-flow events or periods of record to be available for record extension that could not be achieved by using a single index station. Also, the mixed-station procedure can be applied to cases for which an appropriate index station has a shorter record length than the target station.

The mixed-station procedure initially was developed for extension of mean monthly streamflow records rather than for extension of annual peak streamflow records and thus was used with extreme caution during this study. The mixed-station procedure synthesizes peak-flow frequency estimates for individual years of missing record for the target station. Errors in estimated peak flows for individual years might be relatively large with use of the mixed-station procedure. However, the mixed-station procedure was not used in this study to report peak flows for individual years for target stations. Rather, the complete period of record and synthesized annual peak flows for each target station were used to calculate an adjusted mean and standard deviation of the log values of the complete flow record for the purpose of fitting the log-Pearson III distribution. The mixed-station procedure was used for record extension for nine stations (table 3). The number of concurrent years of record between the target and index stations ranged from 11 to 31 (median of 26), and correlation coefficients ranged from 0.80 to 1.00 (median of 0.94).

For stations with frequency results based on recordextension procedures, the "Analysis period" and the "Analysis period length" columns in table 7 represent the combination of the periods of systematic record for the target and index stations. Because the record-extension procedures involve secondary statistical analyses with accompanying errors, the "Analysis period length" for stations with frequency results based on record-extension procedures is not equivalent to the same number of years of systematic record. Further, the uncertainty of the frequency results is larger than would be obtained by collecting systematic records for the same number of years as the reported "Analysis period length."

\section{Historical Adjustment Procedures}

Bulletin 17B recommends the use of historical adjustment procedures in peak-flow frequency analyses when substantiated information indicates that any peak flows that occurred before, during, or after the period of gaged record are the maxima in a period extending beyond the gaged period (U.S. Interagency Advisory Council on Water Data, 1982). The historical adjustment was applied to peak-flow frequency analyses for 17 South Dakota gaging stations. Information regarding large peak flows used in making historical adjustments to systematic records for selected gaging stations is presented in table 4. For some gaging stations listed in table 4, documentation of historical peak flows has been maintained as part of the gaging record. Historical files, newspaper accounts, and systematic records of nearby gaging stations were reviewed to substantiate historical peak flows for other stations.

Adjustments to the period of analysis were made prior to application of the historical adjustments for three stations with intermittent or relatively short periods of systematic record (table 4). These stations include 06445685 and 06482020 , for which systematic records were combined (table 2), and 06478000, for which records were extended by using the mixed-station procedure (table 3 ).

A historical adjustment period extending back to 1881 (121 years) was used for 12 gaging stations in the James and Big Sioux River Basins (table 4). Especially large floods occurred in much of eastern South Dakota during 1881, and documentation of the relative magnitude of subsequent floods for main-stem sites and some large tributaries is substantial. Numerous newspaper reports document extremely high river stages and/or exceptionally large snow pack, which contributed to the large-scale flooding. Especially large peak flows in 1997 were substantiated as the largest peak flows since at least 1881 for six stations on the main stem of the James River (table 4). Flooding in 1997 for many James River tributaries probably was not exceeded between 1881 and 2001; however, sufficient documentation was not available to justify historical adjustments. Large peak flows that occurred during 1969 for 
Table 4. Selected information used in application of historical adjustments.

[--, not applicable]

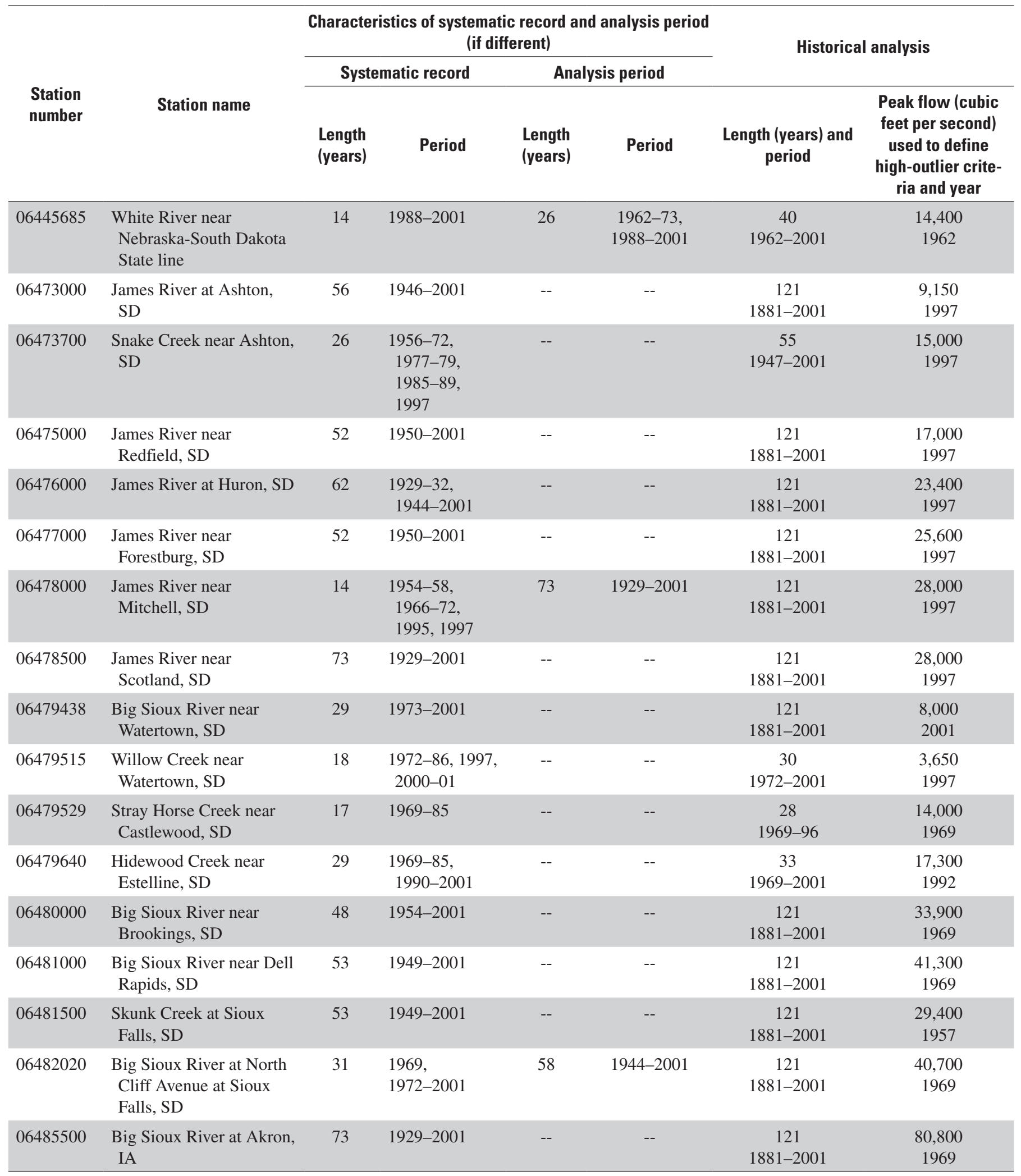


four stations in the lower Big Sioux River Basin and during 2001 for one station in the upper Big Sioux River Basin were substantiated as the largest since 1881 . An especially large peak flow that occurred in 1957 on Skunk Creek in the Big Sioux River Basin (station 06481500; map number 263) also has been documented as the largest since 1881 .

Historical adjustments also were applied for very large peak flows that occurred at four other stations (06473700, 06479515, 06479529, and 06479640; map numbers 195, 245, 247, and 249) on tributaries to the James or Big Sioux River. Historical adjustments also were used for one station on the main-stem White River (06445685; map number 150) in western South Dakota.

Exceptional peak flows occurred at several stations in the Black Hills region associated with a massive thunderstorm during June 9-10, 1972. This flooding, which resulted in at least 237 deaths, was well documented by Schwarz and others (1975) and in many other publications. Historical adjustments would be justifiable for many stations affected by the 1972 flooding. However, large uncertainties concerning an appropriate timeframe to apply to the 1972 flooding preclude the use of a historical adjustment to affected stations. Instead, a mixed-population approach was used to address issues related to flood hydrology of the Black Hills area (including effects of the 1972 flooding), as described in the following section of this report, "Procedures for Gaging Stations in the Black Hills Region."

\section{Procedures for Gaging Stations in the Black Hills Region}

This section describes a regional "mixed-population analysis" that was developed for application to 70 gaging stations in the Black Hills region (fig. 6). A total of 85 gaging stations with 10 or more years of record (through 2001) are located in the region; however, the analysis is applicable only for stations within tributary reaches and excludes eight stations along the main stems of the Cheyenne and Belle Fourche Rivers. Two tributary stations where flows are entirely controlled by releases from major reservoirs also are excluded. Five additional tributary stations are located in proximity to longerterm stations; peak-flow frequency estimates are not reported for these five stations, which are not listed in table 7 or shown on figure 6.

Many gaging stations in the Black Hills region have very large individual peak flows that plot substantially higher than a log-Pearson type III frequency distribution fit to the main body of peak flows for the station. About 25 percent of the stations in the Black Hills region have high outliers, as defined by the Grubbs-Beck outlier test (alpha=0.90; Grubbs and Beck, 1972) that is used in the default Bulletin 17B procedure. About 40 percent of the high outliers for Black Hills region stations are associated with a massive June 9-10, 1972, thunderstorm that generally extended from as far south as Battle Creek to as far north as Bear Butte Creek (Schwarz and others, 1975). In contrast, for all other South Dakota stations that are not within the Black Hills region, about 5 percent have Grubbs-Beck high outliers. Although this is not a rigorous statistical treatment, it is apparent that the relative frequency of occurrence of high outliers is much higher for the Black Hills region than for the rest of the State. The regional mixed-population analysis was developed to address complications associated with the large number of high outliers for the Black Hills region.

Peak flows identified as high outliers in peak-flow frequency analyses generally indicate one of two possibilities: (1) the large peak flows are within the same population of flood events as the main body of peak flows, but have a substantially larger recurrence interval than what is represented by the given period of systematic record, or (2) the large peak flows are associated with a different population of flood events than the main body of peak flows in the systematic record. Gaging stations in various hydrologic settings might be influenced by multiple populations of flood events with differing probability distributions. Mixed-population analyses have been used elsewhere to separate populations of "typical" floods from flooding associated with intense tropical storms or hurricanes. It also is common for northern or mountainous watersheds to experience a mixture of flood events caused by snowmelt, rainfall, or a combination of these factors. Although peak flows in the Black Hills region can be influenced by both snowmelt and rainfall, most particularly large annual peak flows have been recorded during rainfall periods (table 8). Large-scale weather patterns (for example, El Niño/La Niña oscillations) also have been cited as contributing to multiple populations in flood events (Alila and Mtiraoui, 2002). It is not known whether large-scale or local climatic anomalies might result in flood events that have different probability distributions than typical flood-producing storms. The development of the regional mixed-population analysis was justified by the high relative frequency of occurrence of high outliers for the Black Hills region and provided reasonable resolution for two primary problems: (1) an inability to derive realistic frequency estimates for gaging stations where high outliers have been recorded, and (2) an inability to attain reasonable consistency in peak-flow frequency estimates among drainages with similar climatic and hydrogeologic characteristics, but differing by whether or not systematic records include a high outlier.

The regional mixed-population frequency analysis for the Black Hills region identifies two populations of flood events. The population that composes the main body of annual peak flows for a given station is considered the "ordinary-peaks population," and the population of unusually large peak flows that plot substantially above the main body of annual peak flows on a log-probability scale is considered the "high-outlier population." The following major steps were used in developing the regional mixed-population analysis:

1. The applicable region was defined and appropriate gaging stations within the region were identified;

2. All independent annual peak flows and independent high outliers in the regional systematic record were 
defined, from which the relative frequency of occurrence of high-outlier peak flows was determined;

3. The independent high-outlier peak flows were normalized on the basis of drainage area, and a regional probability distribution was determined for the normalized high-outlier peak flows;

4. For each gaging station, the probability distribution for the ordinary-peaks population was initially determined by using the same procedures that were used for other stations in South Dakota;

5. For each gaging station, the normalized high-outlier probability distribution was rescaled on the basis of drainage area, and the site-specific high-outlier probability distribution was defined for the station; and

6. For each gaging station, the final peak-flow frequency distribution was obtained by using jointprobability theory to merge the ordinary-peaks and high-outlier probability distributions.

In the Black Hills region, 36 gaging stations with at least 20 years of systematic record are on tributaries to either the Cheyenne or Belle Fourche Rivers. These stations were investigated to determine the frequency of occurrence of independent high outliers relative to independent annual peak flows within the ordinary-peaks population. The 20-year threshold was selected in an effort to balance between having sufficient systematic record to appropriately define a high outlier for a given station and at the same time having enough stations (and thus enough high outliers) to adequately represent the high-outlier population. All systematic records for the longterm stations were considered when determining the frequency of occurrence of high outliers. Of the 36 long-term stations, 12 had at least one high outlier defined by the default Bulletin 17B procedure. Seven different independent peak flows (table 5) are represented in the 12 stations with high outliers, including only one peak flow from the June 1972 thunderstorm. That peak flow is for station 06414000 (map number 81 ) and is the largest peak flow (relative to normalized drainage area) of all 1972 peak flows represented within systematic records. Contributing drainage areas for the stations listed in table 5 range from 0.47 to $920 \mathrm{mi}^{2}$.

To determine the total number of independent peak flows, the annual peak flows for all long-term gaging stations that were active during any given year were investigated as a group. Independence of peak flows in a given year was determined by investigating the timing and location of peak flows. This analysis resulted in an estimate of 623 independent peak flows in the systematic records of the 36 long-term gaging stations. Thus, the ratio of independent high outliers (7) to the total number of independent peak flows (623) results in a probability of occurrence of a high-outlier peak flow relative to an ordinary peak flow of 0.0112 or once every 89 years. Conversely, the probability of occurrence of an ordinary peak flow in any year is 1.0 minus 0.0112 , or 0.989 .
Accurate estimation of a probability distribution for the high-outlier population on a station-by-station basis was problematic for several reasons. Many gaging stations in the Black Hills region have no peak flows in the high outlier-population represented in their systematic record, and no individual gaging station had more than two independent high outliers. However, it was assumed that the probability of high-outlier peak flows is similar for all drainages in the region.

To address this problem, an analysis was performed to estimate the frequency distribution of the high-outlier population on a regional basis. The peak flows defined as high outliers were normalized relative to drainage area so that peak flows from different sized basins could be combined to develop a regional frequency curve of independent high-outlier peak flows. Regression analyses were performed to determine the relation between contributing drainage area and peak-flow characteristics in log space for 70 gaging stations in the Black Hills region. Drainage area was regressed on both the median and maximum peak flows for the periods of record. The slope of the regression lines averaged about 0.6. Thus, peak flows within the high-outlier population were normalized by dividing the peak flow by the contributing drainage area raised to the 0.6 power.

The normalized peak flows were plotted on a logprobability scale by using the Cunnane formula for determining plotting position, along with the previously calculated probability of having a high-outlier peak in any year (0.0112). The Cunnane formula for determining plotting position is:

$$
C P P=(m-0.4) /(n+0.2)
$$

where

$$
\begin{gathered}
C P P=\quad \text { the Cunnane plotting position for a given peak } \\
\text { flow, } \\
\text { the rank (from largest to smallest) of the given } \\
\text { peak flow within the entire peak-flow } \\
\quad \text { series, and } \\
n=\quad \text { the number of peak flows in the entire peak- } \\
\text { flow series. }
\end{gathered}
$$

As an example, the largest normalized annual peak flow in table $5(3,361)$ is the largest value $(m=1)$ in a total sample of 7 events $(n=7)$. The Cunnane plotting position for this value is 0.0833 , indicating that a normalized peak flow of 3,361 has an exceedance probability of 0.0833 , given that a high-outlier peak flow has occurred. The exceedance probability associated with a normalized peak-flow value of 3,361 for any year is the Cunnane probability plotting position (0.0833) times the conditional probability that any high-outlier peak flow will occur (0.0112), or 0.000933. As indicated on figure 8 , the recurrence interval associated with an exceedance probability of 0.000933 is the reciprocal of the exceedance probability, or about 1,100 years.

A straight-line fit was applied to estimate the normalized probability distribution of the high-outlier population primarily because very few data points were available to appropriately apply a standard probability distribution (such as the 
Table 5. Selected information for annual peak flows representative of the high-outlier population for the Black Hills region.

$\left[\mathrm{mi}^{2}\right.$, square miles; $\mathrm{ft}^{3} / \mathrm{s}$, cubic feet per second $]$

\begin{tabular}{|c|c|c|c|c|c|c|c|}
\hline Station name & $\begin{array}{l}\text { Station } \\
\text { number }\end{array}$ & $\begin{array}{c}\text { Contributing } \\
\text { drainage area } \\
\text { for high-outlier } \\
\text { peak flow } \\
\left(\mathrm{mi}^{2}\right)\end{array}$ & $\begin{array}{c}\text { Drainage area } \\
\left(\mathrm{mi}^{2}\right) \text { raised to } \\
0.6 \text { power }\end{array}$ & $\begin{array}{l}\text { Systematic } \\
\text { record length } \\
\text { (years) }\end{array}$ & $\begin{array}{c}\text { Date of high- } \\
\text { outlier peak } \\
\text { flow (month/ } \\
\text { day/year) }\end{array}$ & $\begin{array}{l}\text { High-outlier } \\
\text { peak flow } \\
\left(f^{3} / s\right)\end{array}$ & $\begin{array}{c}\text { Normalized } \\
\text { peak flow' } \\
\text { (based on } \\
\text { adjusted } \\
\text { drainage } \\
\text { area) }\end{array}$ \\
\hline $\begin{array}{l}\text { Cascade Springs } \\
\text { near Hot Springs, } \\
\text { SD }\end{array}$ & 06400497 & 0.47 & 0.64 & 20 & $8 / 9 / 1996$ & 247 & 389 \\
\hline $\begin{array}{c}\text { Beaver Creek near } \\
\text { Buffalo Gap, SD }\end{array}$ & 06402500 & 130 & 18.55 & 64 & 9/4/1938 & 11,700 & 631 \\
\hline $\begin{array}{l}\text { Castle Creek above } \\
\text { Deerfield Reservoir } \\
\text { near Hill City, SD }\end{array}$ & 06409000 & 79.2 & 13.78 & 53 & $5 / 22 / 1952$ & 1,120 & 81 \\
\hline $\begin{array}{l}\text { Castle Creek above } \\
\text { Deerfield Reservoir } \\
\text { near Hill City, SD }\end{array}$ & 06409000 & 79.2 & 13.78 & 53 & $6 / 17 / 1965$ & 906 & 66 \\
\hline $\begin{array}{l}\text { Rapid Creek at } \\
\text { Rapid City, SD }\end{array}$ & 06414000 & 90 & 14.88 & 61 & 6/9/1972 & 50,000 & 3,361 \\
\hline $\begin{array}{l}\text { Sand Creek near } \\
\text { Ranch A near Beu- } \\
\text { lah, WY }\end{array}$ & 06429905 & 267 & 28.57 & 20 & $5 / 8 / 1995$ & 1,230 & 43 \\
\hline $\begin{array}{l}\text { Redwater River } \\
\text { above Belle } \\
\text { Fourche, SD }\end{array}$ & 06433000 & 920 & 60.02 & 49 & $6 / 16 / 1962$ & 16,400 & 273 \\
\hline
\end{tabular}

${ }^{1}$ Normalized peak flow has units of cubic feet per second divided by drainage area, in square miles, raised to the 0.6 power.

log-Pearson type III distribution). However, for the few data points available, a straight-line fit gave a reasonable approximation of probability relations within the represented range. The fit of the high-outlier distribution deals entirely with very low probability flood events where there is large uncertainty in probability relations. More detailed analysis of probability relations for the limited data set is not justified.

The normalized frequency distribution was applied to annual peak-flow data for applicable gaging stations by using the drainage area for each station to rescale the high-outlier frequency curve shown on figure 8. For example, a gaging station with a drainage area of $100 \mathrm{mi}^{2}$ would have a 500-year high-outlier peak flow value of about $16,600 \mathrm{ft}^{3} / \mathrm{s}$, which is calculated by multiplying 1,050 (taken from figure 8) by 100 raised to the 0.6 power.

For each gaging station, the peak-flow frequency curves for the ordinary-peaks and high-outlier populations were combined into a single frequency curve that represents the probability of a given flood magnitude regardless of cause. The following conditional probability equation (Murphy, 2001) was used to calculate the combined frequency curve:

$$
P_{t}=P_{o c} * P_{o}+P_{h c} * P_{h},
$$

where

$$
\begin{aligned}
& P_{t}=\quad \text { the exceedance probability for a given peak- } \\
& \text { flow magnitude regardless of cause, } \\
& P_{o c}=\quad \text { the conditional exceedance probability for the } \\
& \text { same peak-flow magnitude given that it is } \\
& \text { within the ordinary-peaks population, } \\
& P_{o}=\quad \text { the probability that the annual peak flow is an } \\
& \text { ordinary peak flow (0.989), } \\
& P_{h c}=\quad \text { the conditional exceedance probability for the } \\
& \text { peak-flow magnitude given that it is within } \\
& \text { the high-outlier population, and } \\
& P_{h}=\quad \text { the probability that the annual peak flow is a } \\
& \text { high-outlier peak flow (0.0112). }
\end{aligned}
$$




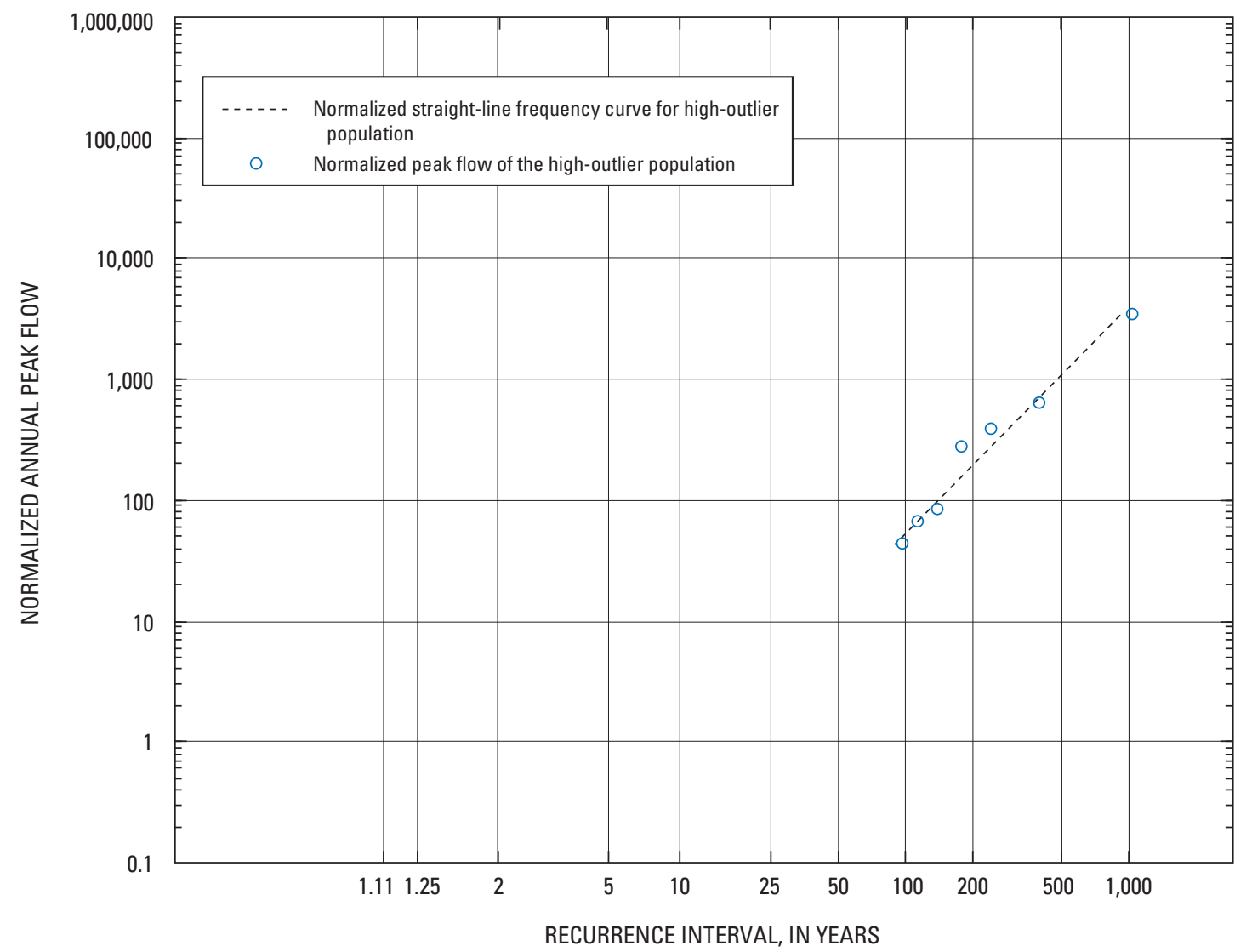

Figure 8. Peak-flow frequency information for normalized high-outlier peak flows of the Black Hills regional mixed-population analysis. Normalized annual peak flow has units of cubic feet per second divided by drainage area, in square miles, raised to the 0.6 power.

The regional peak-flow frequency curve for normalized high-outlier peak flows shown in figure 8 was developed by using the two terms for probability of high-outlier peak flows following the plus sign in equation 2. Example applications of the mixed-population analysis are illustrated in figure 9. Systematic annual peak-flow data for station 06404000 (map number 59) are plotted on a log-probability scale (fig. 9A) using the Cunnane formula. The maximum peak flow during 42 years of systematic record was $26,200 \mathrm{ft}^{3} / \mathrm{s}$ on June 9 , 1972. This peak is defined as a high outlier, so the peak is not assigned a plotting position, but its magnitude is shown with a dot-dashed horizontal line. The uppermost curve on figure $9 A$ shows the fit of the standard Bulletin 17B frequency curve, which was derived by using the default (weighted) skew procedure applied to all systematic peak flows (including the high-outlier peak flow). This curve provides a poor fit to the main body of systematic peak flows and indicates a recurrence interval of about 400 years for the high-outlier peak flow. The solid black curve in figure $9 A$ represents the frequency curve for the ordinary-peaks population and was derived with the high outlier excluded. This curve fits the main body of the annual peak flows better than the standard Bulletin 17B frequency curve, but the recurrence interval for the 1972 peak based on this curve is unrealistically large (greater than 100,000 years). Also shown on figure $9 A$ is a dashed black line representing the frequency curve for high-outlier peaks (developed by rescaling the regional high-outlier frequency distribution to a drainage area of $58.5 \mathrm{mi}^{2}$ for station 06404000). The final curve segment shown on figure $9 A$ is the final frequency curve (thick blue line representing the Black Hills regional mixed-population frequency curve) that was derived by combining the frequency curve for high-outlier peaks with the frequency curve for ordinary peaks. The final frequency curve fits the ordinary-peaks population reasonably well and indicates a recurrence interval of about 880 years for the large 1972 peak.

Figure $9 B$ shows systematic data for station 06404998 (map number 61), which is on Grace Coolidge Creek just south of the heaviest extent of the 1972 thunderstorm. No exceptionally large peak flows have been recorded for this station, and the default Bulletin 17B curve (solid gray line) provides a reasonable fit to the systematic record. Combining the regional high-outlier frequency distribution with the frequency curve for ordinary peak flows results in a frequency curve (thick blue line) that shows substantially larger peakflow magnitudes for recurrence intervals greater than about 


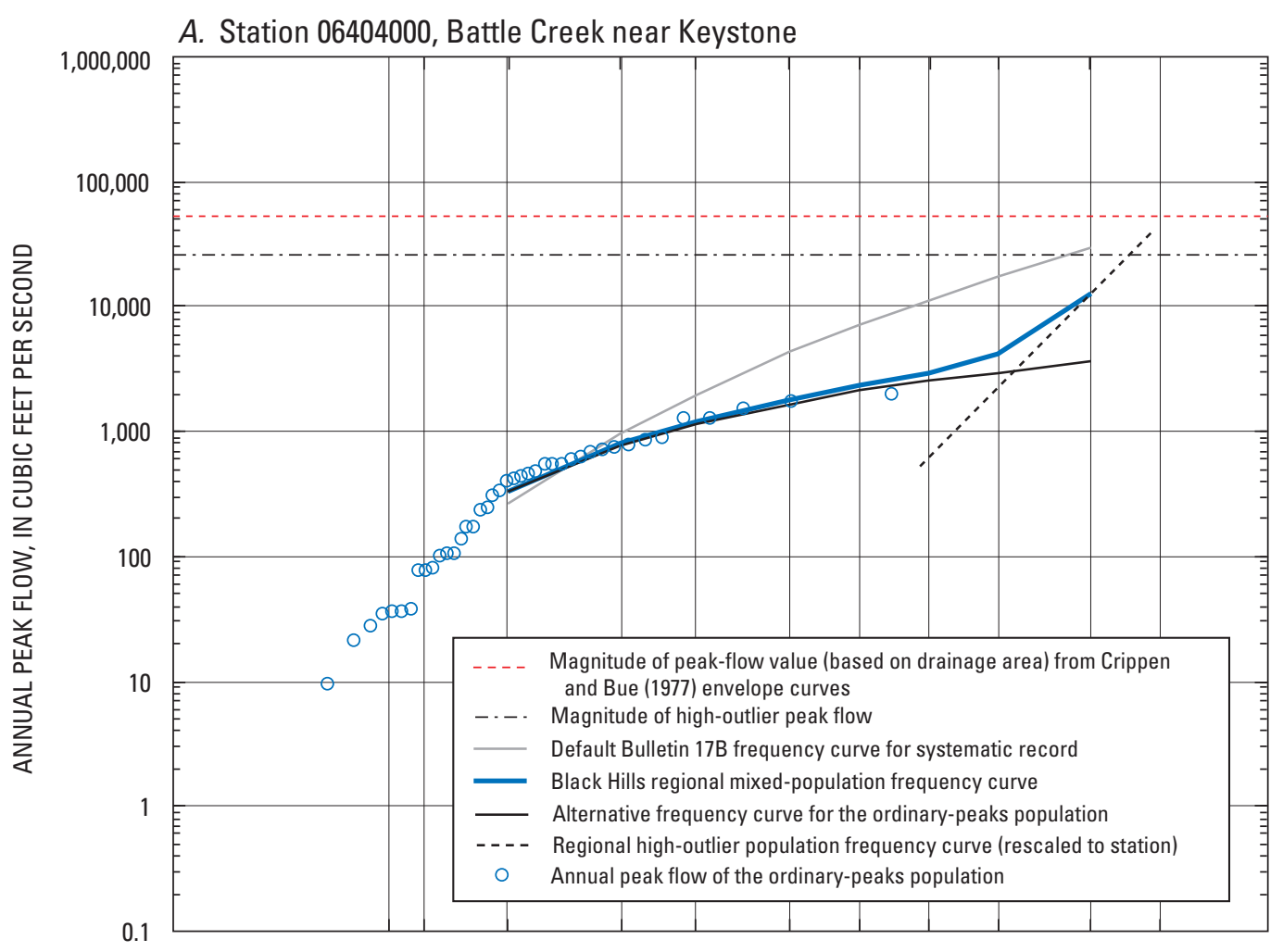

B. Station 06404998, Grace Coolidge Creek near Game Lodge near Custer

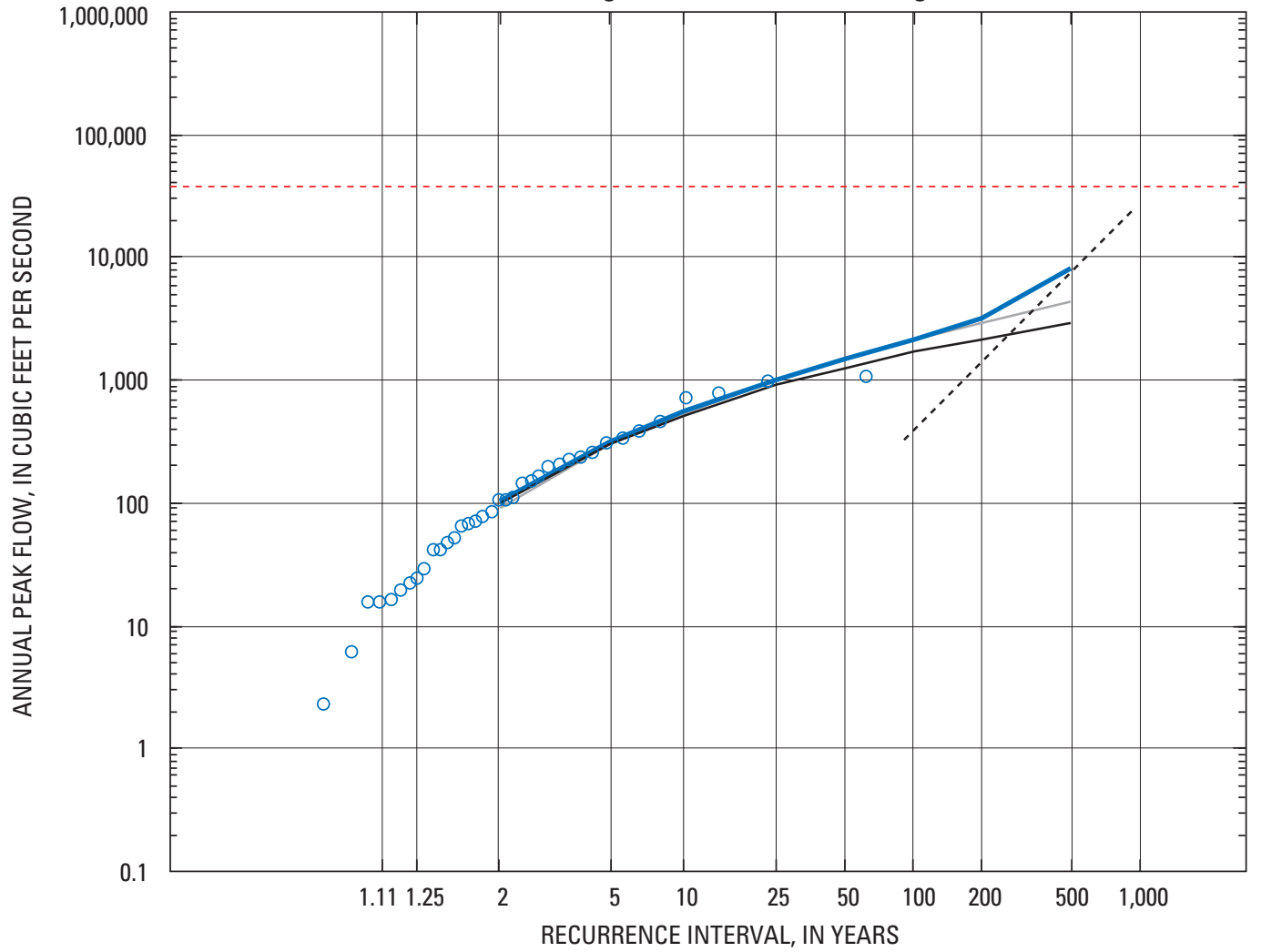

Figure 9. Peak-flow frequency information for $(A)$ Battle Creek near Keystone (06404000) and (B) Grace Coolidge Creek near Game Lodge near Custer (06404998) illustrating application of the Black Hills regional mixed-population analysis. 
100 years than does the frequency curve for the ordinary-peaks population (solid black line). The mixed-population frequency curves for this station and for station 06404000 are very similar. This is consistent with generally comparable potential for extremely large flood events in both basins. Thus, application of the mixed-population approach provides improved consistency for stations in the Black Hills region through integration of regionalized peak-flow characteristics for the largest recurrence intervals, while maintaining the appropriate at-station peak-flow characteristics for the smaller recurrence intervals.

Figures $9 A$ and $9 B$ include horizontal dashed red lines that represent peak-flow values derived from "envelope curves" developed by Crippen and Bue (1977) for region 11, which includes the Black Hills area. The envelope curves bracket maximum recorded flows in the region, and represent a general upper limit (relative to the drainage area) for all known peak flows. Similar horizontal lines are included on plots for all stations in the Black Hills region (Appendix 2), and in no cases were these values exceeded by the estimated peak flows for the 500-year recurrence intervals that were derived by using the mixed-population analysis. On this basis, application of the mixed-population frequency analysis to peak-flow data in the Black Hills region provides peak-flow estimates for large recurrence intervals that do not exceed reasonable upper limits.

Application of the Black Hills regional mixed-population analysis required assigning individual peak-flow values in systematic records to either the ordinary-peaks populations or the high-outlier populations. In most cases, this process was straightforward. However, assignment of the appropriate population was not obvious for some relatively large peak flows, and establishment of strict criteria for making assignments was difficult. Most of the large peak flows identified as GrubbsBeck high outliers were assigned to the high-outlier population, and most peak flows not identified as Grubbs-Beck high outliers were assigned to the ordinary-peaks population. In some cases, however, the specific peak-flow characteristics for a station resulted in a relatively large standard deviation, and some large peak flows did not trigger a significant GrubbsBeck high-outlier result. Thus, in some cases professional judgment was used in assigning a peak flow to the high-outlier population in cases where the peak flow was substantially larger than most other peak flows in the systematic record but was not a Grubbs-Beck high outlier. Conversely, professional judgment was used in assigning some peak flows to the ordinary-peaks population in cases where moderately large peak flows did trigger significant Grubbs-Beck high-outlier results owing to relatively small standard deviations for specific stations.

\section{Characteristics of Gaging Stations and Frequency Analyses by Major River Basin}

This section provides brief descriptions of the major river basins. Characteristics of the gaging networks and issues relating to reliability of peak-flow frequency estimates are described. Years when especially large peak flows occurred and when regulation structures might have affected peak-flow estimates also are described. Table 6 presents characteristics (numbers of stations, record lengths, and drainage-area information) of gaging networks in major river basins.

Considerations that were involved in development of peak-flow frequency estimates also are described in this section. These descriptions include any major considerations that may be applicable for multiple stations within a given basin, and also include descriptions for individual stations, when appropriate.

Many of the long-term stations in South Dakota have moderately large or large drainage areas (as defined in table 6). This typically results from a generally higher demand for hydrologic data for large streams than for small streams. Thus, many of the long-term stations are on the main stems or major tributaries of the major rivers. Records for many of the stations with smaller drainage areas in South Dakota have been collected as part of partial-record networks that have been operated for shorter timeframes. As a result, peak-flow frequency estimates for stations with smaller drainage areas in South Dakota generally have larger uncertainties than estimates for stations on major-river main stems and major tributaries.

\section{Red River of the North and Minnesota River Basins}

Small parts of northeastern South Dakota are within the Red River of the North Basin, which drains to Hudson Bay, and the Minnesota River Basin, which is a tributary to the Mississippi River. Both basins are within a glaciated lowland along the flanks of the Coteau des Prairie physiographic region (fig. 2), and both are characterized by poor drainage with numerous lakes and wetlands. The combined drainage area of the two basins in South Dakota is about 2,240 $\mathrm{mi}^{2}$ (table 6).

Peak-flow frequency estimates are reported in table 7 for two stations in the Red River of the North Basin and for nine stations in the Minnesota River Basin. One long-term station is on the main-stem Minnesota River, which begins downstream from Big Stone Lake. No part of the main-stem Red River of the North is in South Dakota. Ten stations are on tributaries to either the Red River of the North or the Minnesota River 
Table 6. Period-of-record and drainage-area characteristics for gaging stations, by major river basins.

[ $\mathrm{mi}^{2}$, square miles; ND, not determined; E, estimated; NA, not applicable; $\geq$, greater than or equal to; $<$, less than; $>$, greater than; $\leq$, less than or equal to]

\begin{tabular}{|c|c|c|c|c|c|c|c|c|c|c|c|c|c|}
\hline \multicolumn{2}{|c|}{ Characteristic/drainage area } & $\begin{array}{l}\text { Red River } \\
\text { of the } \\
\text { North and } \\
\text { Minnesota } \\
\text { River }\end{array}$ & $\begin{array}{l}\text { Minor } \\
\text { tributar- } \\
\text { ies to } \\
\text { Missouri } \\
\text { River }\end{array}$ & $\begin{array}{l}\text { Grand } \\
\text { River }\end{array}$ & $\begin{array}{l}\text { Moreau } \\
\text { River }\end{array}$ & $\begin{array}{l}\text { Cheyenne } \\
\text { River in } \\
\text { Black Hills } \\
\text { region }\end{array}$ & $\begin{array}{l}\text { Belle } \\
\text { Fourche } \\
\text { River in } \\
\text { Black Hills } \\
\text { region }\end{array}$ & $\begin{array}{c}\text { Cheyenne } \\
\text { River } \\
\text { downstream } \\
\text { from Black } \\
\text { Hills region }\end{array}$ & $\begin{array}{l}\text { Bad } \\
\text { River }\end{array}$ & $\begin{array}{l}\text { White } \\
\text { River }\end{array}$ & $\begin{array}{l}\text { James } \\
\text { River }\end{array}$ & $\begin{array}{c}\text { Vermil- } \\
\text { lion } \\
\text { River }\end{array}$ & $\begin{array}{c}\text { Big } \\
\text { Sioux } \\
\text { River }\end{array}$ \\
\hline \multicolumn{2}{|c|}{ Total drainage area $\left(\mathrm{mi}^{2}\right)$} & ND & ND & 5,390 & 5,245 & 21,200 & 7,240 & 3,000 & 3,180 & 9,980 & 20,900 & 2,600 & 8,850 \\
\hline \multicolumn{2}{|c|}{ Total contributing drainage area $\left(\mathrm{mi}^{2}\right)$} & ND & ND & 5,390 & 5,245 & 21,200 & 7,240 & 3,000 & 3,180 & 9,720 & 16,900 & 2,600 & 7,360 \\
\hline \multicolumn{2}{|c|}{ Drainage area in South Dakota $\left(\mathrm{mi}^{2}\right)$} & 2,240 & ND & 4,700 & 5,245 & E10,000 & 3,270 & 3,000 & 3,180 & 8,310 & 14,600 & 2,600 & 6,010 \\
\hline \multicolumn{2}{|c|}{$\begin{array}{l}\text { Contributing drainage area in South } \\
\text { Dakota }\left(\mathrm{mi}^{2}\right)\end{array}$} & 2,240 & ND & 4,700 & 5,245 & $\mathrm{E} 10,000$ & 3,270 & 3,000 & 3,180 & 8,130 & 10,900 & 2,600 & 4,520 \\
\hline \multicolumn{14}{|c|}{ Main-stem stations } \\
\hline \multirow{6}{*}{$\begin{array}{l}\text { Total number } \\
\text { Number of } \\
\text { stations with } \\
\text { long-term } \\
\text { period of record } \\
\text { ( } \geq 30 \text { years) }\end{array}$} & & 1 & NA & 2 & 4 & 4 & 4 & 2 & 2 & 4 & 8 & 2 & 9 \\
\hline & Total number & 1 & NA & 2 & 2 & 4 & 4 & 2 & 2 & 3 & 6 & 1 & 5 \\
\hline & Very small $\left(<10 \mathrm{mi}^{2}\right)$ & 0 & NA & 0 & 0 & 0 & 0 & 0 & 0 & 0 & 0 & 0 & 0 \\
\hline & $\begin{array}{l}\text { Relatively small }(>10 \\
\text { to } \leq 100 \mathrm{mi}^{2} \text { ) }\end{array}$ & 0 & NA & 0 & 0 & 0 & 0 & 0 & 0 & 0 & 0 & 0 & 0 \\
\hline & $\begin{array}{l}\text { Moderately large } \\
\left(>100 \text { to } \leq 500 \mathrm{mi}^{2}\right)\end{array}$ & 0 & NA & 0 & 0 & 0 & 0 & 0 & 0 & 0 & 0 & 0 & 1 \\
\hline & Large $\left(>500 \mathrm{mi}^{2}\right)$ & 1 & NA & 2 & 2 & 4 & 4 & 2 & 2 & 3 & 6 & 1 & 4 \\
\hline \multirow{5}{*}{$\begin{array}{l}\text { Number of } \\
\text { stations with } \\
\text { intermediate- } \\
\text { length period } \\
\text { of record } \\
\text { (>15 years to } \\
<30 \text { years) }\end{array}$} & Total number & 0 & NA & 0 & 1 & 0 & 0 & 0 & 0 & 1 & 1 & 1 & 3 \\
\hline & Very small $\left(<10 \mathrm{mi}^{2}\right)$ & 0 & NA & 0 & 0 & 0 & 0 & 0 & 0 & 0 & 0 & 0 & 0 \\
\hline & $\begin{array}{l}\text { Relatively small } \\
\left(>10 \text { to } \leq 100 \mathrm{mi}^{2}\right)\end{array}$ & 0 & NA & 0 & 0 & 0 & 0 & 0 & 0 & 0 & 0 & 0 & 1 \\
\hline & $\begin{array}{l}\text { Moderately large } \\
\left(>100 \text { to } \leq 500 \mathrm{mi}^{2}\right)\end{array}$ & 0 & NA & 0 & 0 & 0 & 0 & 0 & 0 & 0 & 0 & 0 & 1 \\
\hline & Large $\left(>500 \mathrm{mi}^{2}\right)$ & 0 & NA & 0 & 1 & 0 & 0 & 0 & 0 & 1 & 1 & 1 & 1 \\
\hline \multirow{5}{*}{$\begin{array}{l}\text { Number of } \\
\text { stations with } \\
\text { short-term } \\
\text { period of record } \\
\text { ( } \leq 15 \text { years) }\end{array}$} & Total number & 0 & NA & 0 & 1 & 0 & 0 & 0 & 0 & 0 & 1 & 0 & 1 \\
\hline & Very small $\left(<10 \mathrm{mi}^{2}\right)$ & 0 & NA & 0 & 0 & 0 & 0 & 0 & 0 & 0 & 0 & 0 & 0 \\
\hline & $\begin{array}{l}\text { Relatively small } \\
\left(>10 \text { to } \leq 100 \mathrm{mi}^{2}\right)\end{array}$ & 0 & NA & 0 & 0 & 0 & 0 & 0 & 0 & 0 & 0 & 0 & 1 \\
\hline & $\begin{array}{l}\text { Moderately large } \\
\left(>100 \text { to } \leq 500 \mathrm{mi}^{2}\right)\end{array}$ & 0 & NA & 0 & 0 & 0 & 0 & 0 & 0 & 0 & 0 & 0 & 0 \\
\hline & Large $\left(>500 \mathrm{mi}^{2}\right)$ & 0 & NA & 0 & 1 & 0 & 0 & 0 & 0 & 0 & 1 & 0 & 0 \\
\hline
\end{tabular}


[mi² , square miles; ND, not determined; E, estimated; NA, not applicable; $\geq$, greater than or equal to; $<$, less than; $>$, greater than; $\leq$, less than or equal to]

\begin{tabular}{|c|c|c|c|c|c|c|c|c|c|c|c|c|c|}
\hline \multicolumn{2}{|c|}{ Characteristic/drainage area } & $\begin{array}{l}\text { Red River } \\
\text { of the } \\
\text { North and } \\
\text { Minnesota } \\
\text { River } \\
\end{array}$ & $\begin{array}{l}\text { Minor } \\
\text { tributar- } \\
\text { ies to } \\
\text { Missouri } \\
\text { River } \\
\end{array}$ & $\begin{array}{l}\text { Grand } \\
\text { River }\end{array}$ & $\begin{array}{l}\text { Moreau } \\
\text { River }\end{array}$ & $\begin{array}{c}\text { Cheyenne } \\
\text { River in } \\
\text { Black Hills } \\
\text { region }\end{array}$ & $\begin{array}{l}\text { Belle } \\
\text { Fourche } \\
\text { River in } \\
\text { Black Hills } \\
\text { region } \\
\end{array}$ & $\begin{array}{c}\text { Cheyenne } \\
\text { River } \\
\text { downstream } \\
\text { from Black } \\
\text { Hills region } \\
\end{array}$ & $\begin{array}{l}\text { Bad } \\
\text { River }\end{array}$ & $\begin{array}{l}\text { White } \\
\text { River }\end{array}$ & $\begin{array}{l}\text { James } \\
\text { River }\end{array}$ & $\begin{array}{l}\text { Vermil- } \\
\text { lion } \\
\text { River }\end{array}$ & $\begin{array}{l}\text { Big } \\
\text { Sioux } \\
\text { River }\end{array}$ \\
\hline \multicolumn{14}{|c|}{ Tributary stations in basin } \\
\hline \multicolumn{2}{|l|}{ Total number } & 10 & 32 & 6 & 7 & 45 & 27 & 7 & 5 & 17 & 39 & 9 & 26 \\
\hline \multicolumn{2}{|c|}{$\begin{array}{l}\text { Contributing drainage area in South Da- } \\
\text { kota divided by number of South Dakota } \\
\text { tributary stations }\end{array}$} & 224 & ND & 783 & 749 & 150 & 121 & 429 & 636 & 478 & 279 & 289 & 174 \\
\hline \multirow{5}{*}{$\begin{array}{l}\text { Number of } \\
\text { stations with } \\
\text { long-term period } \\
\text { of record } \\
\text { ( } \geq 30 \text { years) }\end{array}$} & Total number & 3 & 5 & 3 & 0 & 15 & 6 & 1 & 0 & 6 & 6 & 2 & 2 \\
\hline & Very small $\left(<10 \mathrm{mi}^{2}\right)$ & 0 & 0 & 0 & 0 & 0 & 0 & 0 & 0 & 0 & 0 & 0 & 0 \\
\hline & $\begin{array}{l}\text { Relatively small } \\
\left(>10 \text { to } \leq 100 \mathrm{mi}^{2}\right)\end{array}$ & 0 & 0 & 0 & 0 & 7 & 0 & 0 & 0 & 1 & 1 & 1 & 0 \\
\hline & $\begin{array}{l}\text { Moderately large } \\
\left(>100 \text { to } \leq 500 \mathrm{mi}^{2}\right)\end{array}$ & 2 & 3 & 1 & 0 & 7 & 4 & 0 & 0 & 3 & 2 & 1 & 1 \\
\hline & Large $\left(>500 \mathrm{mi}^{2}\right)$ & 1 & 2 & 2 & 0 & 1 & 2 & 1 & 0 & 2 & 3 & 0 & 1 \\
\hline \multirow{5}{*}{$\begin{array}{l}\text { Number of } \\
\text { stations with } \\
\text { intermediate- } \\
\text { length period } \\
\text { of record } \\
\text { (>15 years to } \\
<30 \text { years) }\end{array}$} & Total number & 0 & 11 & 0 & 2 & 14 & 11 & 5 & 0 & 7 & 21 & 3 & 13 \\
\hline & Very small $\left(<10 \mathrm{mi}^{2}\right)$ & 0 & 6 & 0 & 2 & 8 & 2 & 3 & 0 & 3 & 5 & 1 & 5 \\
\hline & $\begin{array}{l}\text { Relatively small } \\
\left(>10 \text { to } \leq 100 \mathrm{mi}^{2}\right)\end{array}$ & 0 & 2 & 0 & 0 & 2 & 3 & 1 & 0 & 3 & 6 & 2 & 4 \\
\hline & $\begin{array}{l}\text { Moderately large } \\
\left(>100 \text { to } \leq 500 \mathrm{mi}^{2}\right)\end{array}$ & 0 & 2 & 0 & 0 & 4 & 5 & 1 & 0 & 0 & 6 & 0 & 4 \\
\hline & Large $\left(>500 \mathrm{mi}^{2}\right)$ & 0 & 1 & 0 & 0 & 0 & 1 & 0 & 0 & 1 & 4 & 0 & 0 \\
\hline \multirow{5}{*}{$\begin{array}{l}\text { Number of } \\
\text { stations with } \\
\text { short-term } \\
\text { period of record } \\
\text { ( } \leq 15 \text { years) }\end{array}$} & Total number & 7 & 16 & 3 & 5 & 16 & 10 & 1 & 5 & 4 & 12 & 4 & 11 \\
\hline & Very small $\left(<10 \mathrm{mi}^{2}\right)$ & 4 & 7 & 3 & 5 & 11 & 5 & 1 & 1 & 4 & 11 & 4 & 6 \\
\hline & $\begin{array}{l}\text { Relatively small } \\
\left(>10 \text { to } \leq 100 \mathrm{mi}^{2}\right)\end{array}$ & 2 & 5 & 0 & 0 & 2 & 5 & 0 & 2 & 0 & 0 & 0 & 2 \\
\hline & $\begin{array}{l}\text { Moderately large } \\
\left(>100 \text { to } \leq 500 \mathrm{mi}^{2}\right)\end{array}$ & 1 & 2 & 0 & 0 & 3 & 0 & 0 & 2 & 0 & 1 & 0 & 3 \\
\hline & Large $\left(>500 \mathrm{mi}^{2}\right)$ & 0 & 2 & 0 & 0 & 0 & 0 & 0 & 0 & 0 & 0 & 0 & 0 \\
\hline
\end{tabular}


that, given the relatively small combined drainage area of the two basins, are reasonably representative of a large variety in drainage areas. Most of these tributary stations are short term, and the stations with very small and relatively small drainage areas are short term (table 6). The periods of record for all the short-term stations are strongly influenced by either unusually dry conditions (1970-79) or unusually wet conditions (1992-2001) that occurred in eastern South Dakota (fig. 3). Record-extension procedures were applied to all the shortterm stations.

Large annual peak flows occurred in the Red River of the North and Minnesota River Basins during 1952, 1969, 1997, and 2001 (table 8). Occurrence of large peak flows from one or more of these years in the systematic record for a given station generally helps define the upper end of frequency curves.

Peak flows for station 05050000 (map number 1) are influenced by Reservation Dam and White Rock Dam, which are part of the Lake Traverse Project that provides downstream flood control. Peak flows for station 05292000 (map number 8) are regulated by a dam on Big Stone Lake, so peak-flow frequency estimates for this station generally are smaller than for two other upstream stations (05290000 and 05291000; map numbers 5 and 7) that have substantially smaller drainage areas. A large peak flow in 1919 for station 05291000 (table 8) was strongly influenced by an upstream dam failure. This peak is not representative of typical hydrologic conditions and thus was excluded from the peak-flow frequency analysis.

\section{Minor Tributaries to Missouri River}

Peak-flow frequency estimates are provided for 32 gaging stations in drainages that are collectively categorized as "minor tributaries to Missouri River." These stations are interspersed in downstream order among the rest of the major river basins in table 7 as groups $1-6$. The first station in this category (06334500; map number 12) is on the Little Missouri River, which is a tributary to the Missouri River in North Dakota, and has the largest drainage area $\left(1,970 \mathrm{mi}^{2}\right)$ in this category. The Keya Paha River Basin in group 6 (drainage area $=1,070 \mathrm{mi}^{2}$ at station 06464500) is the next largest drainage within this category, and has four gaging stations included in table 7 (map numbers 176-179).

Major influence from individual regulating structures with primary flood control purposes is not known to occur for any of the stations in this group of minor tributaries to Missouri River. Of special note, however, is the 1993 peak flow for station 06439960 (table 8; map number 127) that was strongly influenced by the failure of a stock reservoir just upstream and thus was excluded from the analysis period (table 7).

The stations in this group represent a large variety of drainage areas (table 6) and hydrogeologic conditions. Fourteen of the 16 short-term stations are in eastern South Dakota and have periods of record concentrated in at least one of the two anomalous climatic periods (fig. 3); however, recordextension procedures could be applied for only three of these stations (06361020, 06452320, and 06453250; map numbers 37,172 , and 174). Three short-term stations (06354845, 06358540, and 06453150; map numbers 13, 25, and 173) have only 10 years of record, which are exclusively in very dry years. Peak-flow frequency estimates for these stations probably are substantially biased by period-of-record considerations and do not necessarily provide peak-flow frequency information representative of regional conditions. Comparison of peak-flow frequency estimates for short-term stations 06442900 and 06442950 (located downstream within the same drainage; map numbers 148 and 149) shows substantial differences in peak-flow characteristics that might be associated with the different climatic periods (fig. 3) for these short-term stations.

Large variability exists between stations in this group for the years when large annual peak flows occurred, partly owing to large variability in the geographic locations of the stations. However, most stations with more than 15 years of record have one or more substantial annual peak flows. Although some individual short-term stations probably have biased peak-flow frequency estimates owing to period-of-record considerations, the stations collectively probably provide a reasonable characterization of peak-flow conditions for this group.

\section{Grand River}

The Grand River drains much of northwestern South Dakota, and altitudes in the basin range from about 3,600 ft above NGVD 29 in the headwater areas to about 1,620 ft near the terminus, which is the top of the conservation pool for Lake Oahe (fig. 1). The entire basin is well drained, and steep slopes exist in breaks along the main stem and major tributaries. Most of the basin consists of Cretaceous and Tertiary shales and sandstones (fig. 5; Martin and others, 2004). Soils in some parts of the basin have high clay content with relatively low infiltration capacity. Pasture land is the predominant land use within the basin; however, extensive cultivation occurs in areas with relatively gentle topography and better soils. Many of the breaks areas have tight soils and minimal vegetative cover; thus, streamflow can be very responsive to storm events and recede quickly after precipitation stops. The total drainage area of the Grand River is about 5,390 $\mathrm{mi}^{2}$ of which about 4,700 $\mathrm{mi}^{2}$ is within South Dakota (table 6). The main stem of the Grand River begins downstream from Shadehill Dam, an impoundment at the confluence of the North and South Forks of the Grand River.

Peak-flow frequency estimates are provided for eight stations in the Grand River Basin (table 7). Two long-term stations (map numbers 22 and 23) are on the main stem and have large drainage areas representing about 58 and 100 percent of the Grand River drainage area. Additionally, stations on the North and South Forks of the Grand River are located at sites representing about 3 percent (map number 18), 22 percent (map number 17), and 25 percent (map number 20) of the Grand River drainage area. In general, peak-flow frequency probably is well characterized for the main stem of the Grand 
River. However, drainage areas between 10 and $100 \mathrm{mi}^{2}$ are not represented and the three stations (map numbers 16, 19, and 21) with areas less than $10 \mathrm{mi}^{2}$ have only 10 years of record.

The North Fork of the Grand River has been regulated by Bowman Haley Reservoir (which is in North Dakota) since August 1966; thus, the frequency analysis for station 06355500 (map number 17) was restricted to the regulated period (tables 1 and 7). Similarly, records were truncated for station 06357500 (map number 22), which is immediately downstream from Shadehill Reservoir and has been regulated since 1951. Station 06357800 (map number 23) is much farther downstream from Shadehill Reservoir, and effects of regulation are less pronounced for this station because less than one-half of the drainage area is regulated (table 1). For the period 1967-2001 (that is, after construction of Bowman Haley Dam), large annual peak flows occurred in the Grand River Basin during 1972, 1978, 1987, 1993, 1995, and 1997 (table 8).

\section{Moreau River}

The Moreau River Basin is just south of the Grand River Basin and has many hydrogeologic and land-use characteristics similar to those of the Grand River Basin. Altitudes in the basin range from about 4,000 ft above NGVD 29 in the headwater areas near the Montana/South Dakota border to about $1,620 \mathrm{ft}$ near the terminus, which is the top of the conservation pool for Lake Oahe (fig. 1). The entire basin is well drained, and steep slopes exist in breaks along the main stem and major tributaries. The total drainage area of the Moreau River is about 5,245 $\mathrm{mi}^{2}$ (table 6).

Peak-flow frequency estimates are provided for 11 stations in the Moreau River Basin (table 7). Four stations are on the main stem and two of these are long term. One of the longterm stations (06360500) includes combined records from a shorter term station (table 3 ). Record-extension procedures using the long-term stations as index stations were applied for the other two main-stem stations with shorter periods of record (06359000 and 06360000; map numbers 29 and 34). Peakflow frequency is well characterized for the main stem with four stations (map numbers 29, 31, 34, and 36) representing about 30, 51, 82, and 93 percent of the Moreau River drainage area. The most notable high-flow years along the main stem were 1952, 1953, and 1997 (table 8).

Seven stations are on tributaries to the Moreau River. All of these have very small drainage areas (table 6), and five are short term. Record-extension procedures were not applied for any of the tributary stations. Because of the short periods of record, peak-flow frequency for very small basins (less than $10 \mathrm{mi}^{2}$ ) is not well characterized, and peak-flow frequency information for drainage areas between 10 and $500 \mathrm{mi}^{2}$ is lacking entirely.

Numerous stock reservoirs are within the Moreau River Basin. However, major influence from individual regulating structures with flood control purposes is not known to occur for any of the stations.

\section{Cheyenne River}

The Cheyenne River heads in northeastern Wyoming and flows around the southern and eastern flanks of the Black Hills to its confluence with the Missouri River in central South Dakota. Altitudes in the basin range from more than $7,000 \mathrm{ft}$ above NGVD 29 at the highest peaks in the Black Hills to about 1,620 ft near the terminus, which is the top of the conservation pool for Lake Oahe (fig. 1). The largest tributary is the Belle Fourche River, which heads in northeastern Wyoming and flows around the northern flanks of the Black Hills. The geology and physiography of the basin are complex. Upstream from the confluence of the Cheyenne and Belle Fourche Rivers, hydrogeology is dominated by the mountainous terrain of the Black Hills (figs. 2 and 5). The remainder of the basin is within the Great Plains physiographic division (fig. 2) and generally is well drained, with steep slopes in breaks along the main-stem and major tributary channels. The total drainage area of the Cheyenne River is about 24,200 $\mathrm{mi}^{2}$, of which about 13,000 $\mathrm{mi}^{2}$ is in South Dakota (table 6). The total drainage area of the Belle Fourche River is about $7,240 \mathrm{mi}^{2}$, of which about 3,270 $\mathrm{mi}^{2}$ is in South Dakota.

\section{Cheyenne River and Belle Fourche River Main Stems}

Six long-term gaging stations are on the Cheyenne River main stem with areas ranging from about 7,140 to 23,900 $\mathrm{mi}^{2}$, and four long-term stations are on the Belle Fourche River main stem with areas ranging from 3,280 to 7,210 $\mathrm{mi}^{2}$. A common base period (1946-2001) was used for all regulated main-stem stations, as described in the previous section "Procedures for Gaging Stations Affected by Regulation." Of the 10 main-stem stations on the Cheyenne and Belle Fourche Rivers, 5 have complete systematic records for the entire base period. Two stations (06395000 and 06428500; map numbers 40 and 90) are missing the first year of the base period (1946); however, no adjustments were made for this missing year. Substantial adjustments were made for three other stations to produce peak-flow frequency estimates representative of the base period. For station 06400500 (map number 48), the twostation analysis was used, and for station 06438500 (map number 118), the mixed-station analysis was used (table 3 ). For station 06439300 (map number 124), records were augmented with records for station 06439500 (table 2), prior to extension by using the mixed-station analysis (table 3 ).

Peak-flow frequency is well characterized for the Cheyenne River and Belle Fourche River main stems. Cheyenne River main-stem stations (map numbers 40, 48, 51, 86, 118, and 124) represent about 30, 36, 38, 53, 89, and 99 percent of the drainage area. Belle Fourche River main-stem stations (map numbers 90, 105, 113, and 117) represent about 45, 63, 81 , and 100 percent of the drainage area. 
Station 06401500 (map number 51) is on the Cheyenne River just downstream from Angostura Dam, which was completed in October 1949. Station 06428500 (map number 90) is on the Belle Fourche River and is not far downstream from Keyhole Dam (in Wyoming), which was completed in October 1952. Use of the 1946-2001 base period for these stations resulted in inclusion of a few years of unregulated systematic record in the period of analysis. However, detailed examination of the 1946-49 annual peak flows indicated that typical reservoir operations probably would not have substantially altered the recorded peak flows.

Flows of the Belle Fourche River also are affected by a diversion to Belle Fourche Reservoir, which is an off-stream reservoir east of Belle Fourche. The diversion canal (Inlet Canal) was completed in June 1914 and has a capacity of about $1,500 \mathrm{ft}^{3} / \mathrm{s}$. The effect of this diversion can be substantial for many peak flows at station 06436000 (map number 105), which is about 5 miles downstream. Effects become relatively minor, however, for other stations progressively farther downstream.

Prior to the base period, especially large annual peak flows occurred during 1920 (station 06400500) and during 1933 (station 06439500). Relatively large annual peak flows have occurred at many sites during the base period. Some of the more notable years are 1947, 1962, 1964, 1978, 1982, 1995, and 1996.

\section{Cheyenne and Belle Fourche River Tributaries in the Black Hills Region}

Peak-flow frequency estimates (table 7) are provided for 72 tributary gaging stations in the Black Hills region (fig. 6). Altitudes range from more than 7,000 ft above NGVD 29 at the highest peaks in the Black Hills region to about 2,100 ft at the confluence of the Cheyenne and Belle Fourche Rivers. The total drainage area of the Black Hills region within South Dakota is about $10,500 \mathrm{mi}^{2}$.

The density of the gaging network in the Black Hills region is the highest in South Dakota (fig. 1). Tributaries to the Cheyenne River have 45 gaging stations, and tributaries to the Belle Fourche River have 27 gaging stations, which represents an average of one gaging station for every 150 and $121 \mathrm{mi}^{2}$, respectively. The distribution of long-, intermediate-, and short-term stations is fairly uniform.

Selected alternatives for peak-flow frequency estimates for nearly all tributary stations within the Black Hills region were developed by using the Black Hills regional mixedpopulation analysis. In general, this approach consists of first evaluating results of the default Bulletin 17B analysis for any given station and selecting an alternative analysis, when appropriate, to represent the frequency distribution for the "ordinary peaks" population. Next, a "high outlier" distribution for each station was obtained by rescaling the regional high-outlier distribution relative to the drainage area for the station. The final frequency distribution was then obtained by using joint-probability theory to combine the distributions for the two populations.

The Black Hills region is geologically complex, and peak-flow characteristics can be highly influenced by the hydrogeologic settings (fig. 6) that were described previously. The largest influences are within the limestone-headwater and loss-zone settings, where peak flows can be suppressed relative to peak flows in the other hydrogeologic settings. Within all the hydrogeologic settings, site-specific variability can result in peak-flow characteristics that deviate from typical patterns in the settings. In general, peak-flow characteristics within the other hydrogeologic settings (that is, the crystallinecore, artesian-spring, and exterior settings) generally are less distinctive and can be subject to a larger variety of hydrogeologic influences within each setting, such as more variable geology, topography, and soil characteristics.

Peak-flow characteristics within the limestone-headwater setting are very distinctive and are best typified by records for three stations (06392900, 06408700, and 06429500; map numbers 38,72, and 91). Of these three stations, peak-flow characteristics are most distinctively suppressed for station 06408700. This is evidenced by comparing the maximum and minimum annual peak flows of 17 and $4.3 \mathrm{ft}^{3} / \mathrm{s}$, respectively (see table 8 in Appendix 1), which is less than a four-fold difference, and by comparing these values to the largest and smallest daily mean values $\left(12 \mathrm{ft}^{3} / \mathrm{s}\right.$ and $3.1 \mathrm{ft}^{3} / \mathrm{s}$, respectively) that have been recorded during 1982-2001 (U.S. Geological Survey, 2002). Five other stations (06392950, 06408900, 06409000, 06430770, and 06430850; map numbers 39, 74, 75, 95 , and 97) are primarily influenced by these hydrogeologic characteristics, as evidenced by the relatively flat frequency curves for these stations (figs. 11.39, 11.74, 11.75, 11.95, and 11.97 in Appendix 2).

For these eight example limestone-headwater stations, the calculated high-outlier probability distribution derived from the mixed-population analysis plots substantially above the ordinary-peaks distribution. This causes very abrupt increases in slopes of the final mixed-population frequency curves in the range of recurrence intervals between about 50 and 100 years, and the relative increases in peak-flow frequency estimates are much larger than for most stations in other hydrogeologic settings in the Black Hills region. It also is noted that two high-outliers for example station 06409000 (map number 75) were used in development of the frequency distribution for the high-outlier population; however, the normalized peak flows (relative to adjusted drainage area) are about an order of magnitude smaller than most of the other normalized peak flows listed in table 5. On this basis, application of the mixed-population analysis probably results in overestimation of peak flows for large recurrence intervals for stations where drainage areas are primarily within the limestone-headwater setting. However, peak-flow frequency estimates derived from the mixed-population analysis are reported as the selected alternative because (1) especially large uncertainty exists for large recurrence intervals for all of the Black Hills region, 
(2) Bulletin 17B default procedures may substantially underestimate peak-flow frequencies for large recurrence intervals in the limestone-headwaters setting, and (3) it is considered appropriate to maintain consistency in methods for the Black Hills region. In general, peak-flow frequency estimates for the eight aforementioned stations probably characterize peakflow conditions in the limestone-headwater setting very well for relatively small recurrence intervals. However, peak-flow frequency estimates for larger recurrence intervals should be used with caution.

It is noted that similar abrupt increases in slopes of frequency curves result from application of the mixed-population analysis for many stations in other hydrogeologic settings that individually have relatively suppressed peak-flow characteristics, which can result from a variety of different hydrogeologic conditions. Thus, potential probably exists for overestimation of peak flows for large recurrence intervals for other stations in other hydrogeologic settings; however, this potential cannot be categorized for other stations.

Areas within the crystalline-core hydrogeologic setting generally have much higher peak-flow potential than areas within the limestone-headwater setting. However, it is not possible to identify individual gaging stations within the crystalline-core setting that typify peak-flow characteristics because of large variability in factors such as geology, topography, and soil characteristics. For interested users, additional insights could be obtained by examination of data for various stations within drainage basins for French Creek (map numbers 56 and 57), Battle Creek (map numbers 58-62), and Spring Creek (map numbers 66-70). Drainage areas for these stations are primarily within the crystalline-core setting, with only minor influence for several stations from hydrogeologic conditions within the upstream limestone-headwater setting. Minor effects from potential attenuation of peak flows within relatively small pass-through reservoirs (table 1) can occur for several of the downstream stations within these groups. In general, peak-flow conditions within the crystalline-core setting are well characterized by a relative abundance of stations with large variability in drainage areas and periods of record.

Within the loss-zone hydrogeologic setting, substantial reduction of relatively small peak flows can occur during periods when channels within and downstream from loss zones are dry prior to the onset of high-flow conditions. This can result in suppression of peaks for small recurrence intervals. A good example is provided by figure 10, which shows concurrent systematic records (1981-2001) for stations 06422500 and 06423010 (map numbers 84 and 85) plotted on a log-probability scale with accompanying Bulletin 17B frequency curves (determined by using station skews). Both stations are along Boxelder Creek, and an extensive streamflowloss zone exists between the two stations. Another example is provided by the graph of the systematic data (fig. 11.71 in Appendix 2) for station 06408500 (map number 71) along Spring Creek. Magnitudes of many of the smaller peak flows (generally less than about 2- to 5-year recurrence intervals) have been reduced owing to the influence of an upstream loss zone. Potential exists for similar influences along many other stream reaches; however, stream-specific data generally would be needed to quantify effects for individual streams.

Effects for the artesian-spring setting cannot be typified because influences are minimal and generally are limited to maintaining saturation along alluvial channels downstream from artesian springs. However, application of the mixedpopulation analysis is appropriate for this setting, as demonstrated by examination of the frequency plot (fig. 11.47 in Appendix 2) for station 06400497 (map number 47), which is in a very small drainage $\left(0.47 \mathrm{mi}^{2}\right)$ that is dominated by artesian spring discharge. The largest peak flow for this station was identified as a high outlier (table 8) and was used in development of the Black Hills high-outlier population (table $5)$.

A wide variety of physical conditions exist within the exterior hydrogeologic setting; thus, peak-flow characteristics cannot necessarily be typified, especially for smaller drainages. For many of the large drainages, however, decreasing channel gradients and broadening flood plains occur where streams transition into the exterior setting from other settings upstream, which can result in increasing potential for attenuation of peak flows in a downstream direction. A good example is provided by the systematic data (table 8 ) and frequency plots (figs. 11.81 and 11.82 in Appendix 2) for stations 06414000 and 06421500 (map numbers 81 and 82), which are along Rapid Creek. The 1972 peak attenuated from about $50,000 \mathrm{ft}^{3} / \mathrm{s}$ at the upstream station to $7,320 \mathrm{ft}^{3} / \mathrm{s}$ at the downstream station (exterior setting). An exception to the aforementioned generality is illustrated by two stations ( 06436190 and 06436198; map numbers 108 and 109; figs. 11.108 and 11.109 in Appendix 2) along Whitewood Creek, where peak-flow estimates indicate generally increasing peak-flow potential in a downstream direction. This is consistent with the current channel geomorphology in lower Whitewood Creek, which has been altered substantially by deposition of massive volumes of mine tailings that straightened numerous meanders and increased the channel gradient (Goddard, 1989).

Many Black Hills drainages are composed of areas representing two or more hydrogeologic settings. Hydrogeologic characteristics of drainage areas with mixed settings should be considered prior to extrapolation of at-site peakflow frequency estimates provided in this report. A good example is provided by two stations along Beaver Creek on the southeastern flank of the Black Hills. Examination of the systematic data (table 8) and frequency curve (fig. 11.54 in Appendix 2) for short-term station 06402430 (map number 54) indicates generally suppressed peak-flow characteristics that probably can be partially attributed to outcrops of the Madison Limestone along the southwestern part of the drainage area. The largest peak flow within the systematic record $\left(90 \mathrm{ft}^{3} / \mathrm{s}\right)$, however, probably reflects influence from the crystalline-core setting, which composes a substantial part of the drainage area. Long-term station 06402500 (map number 55) is within the exterior setting, and the intervening reach contains an extensive loss zone and a large artesian spring. Examination 


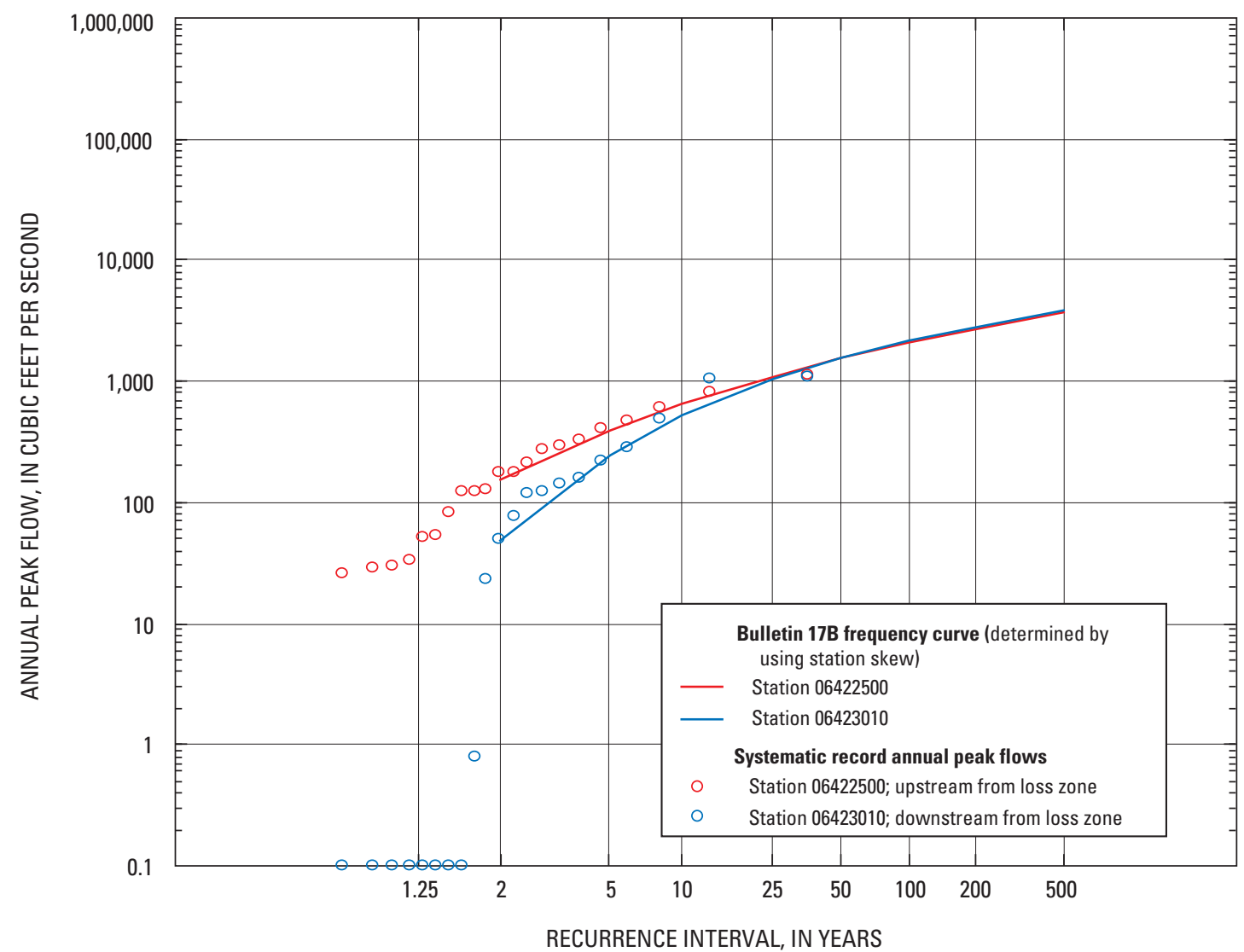

Figure 10. Peak-flow frequency information illustrating influences of the loss-zone hydrogeologic setting. Data shown are for 1981-2001 for stations 06422500 (Boxelder Creek near Nemo; drainage area 96 square miles) and 06423010 (Boxelder Creek near Rapid City; drainage area 128 square miles).

of the systematic peak-flow data (table 8) and time-series plot (fig. 11.55 in Appendix 2) for this station indicates an abundance of small peak flows and a general absence of large peak flows during recent years. However, interviews with area landowners and staff from various land-management agencies have failed to identify known changes in physical conditions within the drainage area that would have caused changes in peak-flow conditions. The aforementioned differences in hydrogeologic characteristics and the question regarding stationarity precluded application of record extension procedures for the short-term upstream station. Similar, but less complicated circumstances also precluded record extensions for many other stations in the Black Hills region. These procedures were applied for only a few cases where index stations existed along the same stream channel within areas with comparable hydrogeologic characteristics. Record-extension procedures were applied only for stations 06402995, 06404998, 06406500, 06436180, 06436198, 06436760, and 06436800 (tables 2 and 3 ; map numbers 56, 61, 65, 107, 109, 111, and 112).

It is noteworthy that the largest peaks for stations 06402000 and 06402500 (map numbers 52 and 55) occurred on the same date in 1938 (table 8). Very little documentation is available regarding these peaks; however, it is apparent that a storm of substantial intensity, duration, and areal coverage would be needed to cause the recorded peak flows in two different drainage basins. Various (uncited) newspaper accounts also reported flooding along the Fall River in 1937 that was comparable to flooding in 1938. Both of these floods occurred prior to construction of two flood-control reservoirs upstream from station 06402000 (table 1).

The mixed-population analysis was not applied for two stations in the Rapid Creek Basin (06410000 and 06411500; map numbers 76 and 78) that are located immediately downstream from major regulating structures (table 1). The drainage area upstream from Deerfield Dam also composes a substantial part of the drainage area of station 06410500 (map number 77), and the drainage area upstream from Pactola Dam accounts for a substantial part of the drainage area for downstream stations on Rapid Creek, including stations 06412500, 06414000, and 06421500 (map numbers 79, 81, and 82). Thus, when applying the mixed-population analysis to these stations, only the contributing drainage area downstream from the primary regulating structure was used to rescale the high-outlier population for the site-specific frequency analysis. Similarly, rescaling for station 06402000 (map number 52) 
included subtraction of drainage areas upstream from two flood-control structures in the upper Fall River Basin.

Several other moderate-sized regulating structures that are operated as pass-through reservoirs presumably cause at least minor attenuation of some peak flows but do not necessarily have substantial effects on peak-flow characteristics for downstream gaging stations. Included in this category are Stockade Lake on French Creek, Center Lake on Grace Coolidge Creek, and Sheridan Lake on Spring Creek (table 1). Various other small regulating structures exist within the Black Hills region; however, their potential effects on peak-flow characteristics are considered minimal.

Large annual peak flows occurred in tributaries in various parts of the Black Hills region during 1938, 1952, 1955, 1962, 1972, 1976, 1982, and 1996 (table 8). Individual peak flows that occurred in nearly all these years were used in defining frequency relations for the regional high-outlier population.

A large peak for station 06405800 (Bear Gulch near Hayward; map number 62) occurred in 1989 (table 8), about 1 year after almost the entirety of the drainage area was essentially denuded following an intensive wildfire (Driscoll and others, 2004). This peak was truncated prior to application of the mixed-population analysis because it is not representative of typical conditions for the drainage.

Estimation of the return period for the destructive 1972 flooding in the Rapid City area has persisted as a question ever since the flood. The mixed-population analysis indicates recurrence intervals for the 1972 peak flows of slightly less than 1,000 years for stations 06412500 and 06414000 (map numbers 79 and 81; figs. 11.79 and 11.81 in Appendix 2) and slightly less than 200 years for station 06421500 (map number 82; fig. 11.82). Recurrence intervals for most other stations where high-outlier peak flows were recorded during 1972 also fall into a general range of about several hundred years to 1,000 years. The uncertainty regarding these estimates cannot be statistically defined and is quite large. However, the mixed-population analysis might provide a more realistic perspective than can be obtained by using the default Bulletin 17B procedure. Also, and perhaps more importantly, for most stations that were affected by the 1972 event (or other highoutlier peak flows), the mixed-population analysis results in peak-flow frequency estimates in the 25- to 100-year range that are much more consistent with systematic records.

\section{Cheyenne River Tributaries Downstream from the Black Hills Region}

Seven gaging stations are on tributaries to the Cheyenne River downstream from the confluence with the Belle Fourche River. The total drainage area of the Cheyenne River Basin downstream from the confluence of the Belle Fourche River is about 3,000 $\mathrm{mi}^{2}$ (table 6). Given the relatively small drainage area of this part of the Cheyenne River Basin, the tributary stations are reasonably representative of a wide variety of drainage areas (table 6). Six of the stations have either long-term or intermediate record lengths and have drainage areas ranging from very small to large. In general, peak-flow frequency is reasonably well characterized for tributaries in this reach of the Cheyenne River. However, most of the stations with very small drainage areas are located in proximity.

Large annual peak flows occurred in tributaries of the lower Cheyenne River during 1962, 1967, 1978, 1982, and 1996 (table 8). Occurrence of large peak flows from one or more of these years in the systematic record for a given station generally helps define the upper end of frequency curves.

\section{Bad River}

The Bad River heads just southeast of the confluence of the Cheyenne and Belle Fourche Rivers, and altitudes in the basin range from about 2,800 ft above NGVD 29 in the headwater areas to about 1,420 ft near the confluence with the Missouri River downstream from Oahe Dam. This basin is composed primarily of outcrops of the Cretaceous-age Pierre Shale, with outcrops of other Cretaceous and Tertiary rocks in the headwater areas (fig. 5; Martin and others, 2004). Soils in the basin tend to have high clay content with relatively low infiltration capacity. The total drainage area of the Bad River is about 3,180 $\mathrm{mi}^{2}$ (table 6).

Peak-flow frequency estimates are provided for seven stations in the Bad River Basin. Two long-term stations are on the main stem and have large drainage areas (table 6). These stations (map numbers 130 and 134) represent about 46 and 98 percent of the drainage area. In general, peak-flow frequency probably is well characterized for the Bad River main stem.

Five stations are on tributaries to the Bad River (table 6), that given the relatively small drainage area of the Bad River, are reasonably representative of a variety of drainage areas. All five tributary stations are short term. Record-extension procedures were applied only for station 06440200 (map number 128 ) by using the two-station analysis (table 3 ). In general, peak-flow frequency estimates for very small and small basins probably are not well characterized, primarily owing to short periods of record.

Numerous stock reservoirs exist within the Bad River Basin; however, major influence from individual regulating structures with flood control purposes is not known to occur for any of the gaging stations. Large annual peak flows occurred in the Bad River Basin during 1952, 1967, 1978, 1991, and 1996 (table 8).

\section{White River}

The White River heads within northwestern Nebraska and flows into South Dakota near Slim Butte. Altitudes in the basin in South Dakota range from about 3,200 ft above NGVD near the Nebraska border to about 1,365 ft where the White River enters Lake Francis Case (fig. 1). Surficial geology transitions from the Pierre Shale and other Cretaceous rocks near the Nebraska border (fig. 5) to various Tertiary deposits 
just downstream that include the Arikaree Formation and the White River Group (Martin and others, 2004). Extensive areas with badlands topography occur from approximately where the White River begins to flow in a northeasterly direction (near map number 152 in figure 1) through the remainder of the Tertiary deposits. These areas are typified by very steep slopes with minimal vegetation cover and highly erodible clays soils. In contrast, in the vicinity of the Sand Hills physiographic division near the Nebraska border (fig. 2), Quaternary deposits of wind-blown sands (fig. 5) have particularly high infiltration capacities. Sandy soils derived from the Tertiaryage Ogallala Formation also occur in much of the drainage basin of the Little White River, which is the largest tributary to the White River. The total drainage area of the White River is about $9,980 \mathrm{mi}^{2}$, of which about $8,310 \mathrm{mi}^{2}$ is in South Dakota (table 6). The total drainage area of the Little White River is about $1,650 \mathrm{mi}^{2}$, of which about 1,580 $\mathrm{mi}^{2}$ is in South Dakota and about $260 \mathrm{mi}^{2}$ does not contribute to surface-water runoff.

Peak-flow frequency estimates are provided for 21 stations in the White River Basin (table 7). Five stations are on the main stem of the White River and have large drainage areas (table 6). Three of these stations are long term. One intermediate-record length station (06445685; map number 150) on the main stem of the White River has a drainage area of 1,440 $\mathrm{mi}^{2}$. The analysis period for this station was obtained by combining systematic records for stations 06445685 and 06445700 (table 2). Although the drainage areas for these two stations are very similar (within about 4 percent), examination of 7 years of concurrent record (table 8) shows that peak flows attenuated between the stations in all years, and sometimes this attenuation was substantial. Combining records for the two stations substantially increased the available peak-flow information for this general reach of the main-stem White River; however, the reported peak-flow frequency estimates for station 06445685 might not be entirely representative of the specific location of that station.

Peak flows for stations 06445685 and 06447000 (table 8; map numbers 150 and 157) indicate substantial variability that might be due to variable effects of attenuation and large tributary inflows. In this reach, large areas with badlands topography have very large peak-flow potential, as exemplified by four stations (06446250, 06446400, 06446430, and 06446550; map numbers 153-156), for which numerous large peaks have been recorded (table 8) relative to the small drainage areas. An example of the large variability in peak flows within this reach is illustrated by a large peak of $9,240 \mathrm{ft}^{3} / \mathrm{s}$ recorded at station 06445700 (drainage area 1,500 $\mathrm{mi}^{2}$ ) in June 1967 (table 8). Proceeding downstream, the peak flow at station 06446000 (drainage area 2,200 $\mathrm{mi}^{2}$; map number 152) had substantially attenuated to $3,270 \mathrm{ft}^{3} / \mathrm{s}$, but the peak flow at station 06446200 (drainage area 3,000 $\mathrm{mi}^{2}$; this station has only 9 years of systematic record and is not included in table 7) had increased to $11,800 \mathrm{ft}^{3} / \mathrm{s}$ (table 8).

Stations on the main stem (map numbers 150, 152, 157, and 170) represent about 14, 22, 50, and 100 percent of the White River drainage area. In general, peak-flow frequency probably is well characterized for the main stem from near station 06447000 (map number 157) and downstream. Farther upstream, peak-flow frequency for station 06446000 (map number 152) also is well characterized, but substantial differences in peak-flow characteristics along the main stem may be possible at locations close to this station. Peak-flow frequency estimates for station 06445685 (map number 150) probably are not well characterized.

Five stations are on the main stem of the Little White River, which accounts for about 20 percent of the White River drainage area in South Dakota. Four of these stations are long term, and records for the fifth station (06449300; map number 163) were extended on the basis of records for nearby station 06449500 (table 3; map number 165). Stations on the main stem (map numbers 158, 161, 163, 164, and 168) represent about 19, 36, 54, 62, and 95 percent of the Little White River drainage area; thus, peak-flow frequency is well characterized for the main stem.

Six additional stations are on other tributaries to the White River and represent a wide range of drainage areas (ranging from about 0.2 to $340 \mathrm{mi}^{2}$ ). Record lengths are either intermediate or long term for five of these stations. Six more stations on tributaries to the Little White River also represent a wide range of drainage areas (ranging from about 2.5 to $120 \mathrm{mi}^{2}$ ), and four of these stations have intermediate-length or long-term records. Two of these stations (06448000 and 06449250; map numbers 159 and 162) are influenced by noncontributing drainage areas and sandy soils in the Sand Hills physiographic division (fig. 2), resulting in distinctively small peak-flow characteristics, relative to drainage area. In general, peak-flow frequency is reasonably well characterized for tributaries in the Little White River Basin; however, available data for tributaries to the remainder of the White River Basin are very sparse.

Lake Creek in the upper Little White River Basin has been consistently regulated since the 1930 s by a series of dams in the Lacreek National Wildlife Refuge. Large annual peak flows occurred in the White River Basin during 1942, 1952, 1967, and 1999 (table 8).

\section{James River}

Altitudes along the main stem of the James River range from about 1,200 ft above NGVD 29 at the North Dakota/ South Dakota border to about 1,150 ft near the confluence with the Missouri River downstream from Lewis and Clark Lake. A substantial part of the basin extends into North Dakota. In South Dakota, the basin is largely within the glaciated James River Lowlands physiographic division (fig. 2), which is characterized by poor drainage with numerous lakes and wetlands. The total drainage area of the James River is about $20,900 \mathrm{mi}^{2}$, of which about $14,600 \mathrm{mi}^{2}$ is in South Dakota and about 4,000 $\mathrm{mi}^{2}$ does not contribute to surfacewater runoff (table 6).

Peak-flow frequency estimates are provided for 47 stations in the James River Basin. Eight stations are on the main 
stem and all have large drainage areas (table 6). Six of these stations are long term, and several of these stations were used as index stations in extending records for two other main-stem stations. Main-stem stations (map numbers 180, 187, 191, 204, 209, 211, 216, and 226) represent about 28, 42, 47, 67, 76, 84, 91, and 99 percent of the James River drainage area. In general, peak-flow frequency is well characterized for the James River main stem.

Thirty-nine stations are on tributaries to the James River (table 6) and represent a large variety of drainage areas. Many short-term tributary stations with very small drainage areas have periods of record concentrated in the 1970s (table 7) when dry climatic conditions predominated in eastern South Dakota (fig. 3). Record-extension procedures were investigated for all the short-term tributary stations; however, suitable correlations with long-term index stations did not exist, and record extensions for smaller basins were unsuccessful. Three of the short-term stations (06473350, 06477140, and 06478400; map numbers 193, 212, and 225) have only 10 years of record, which are exclusively in very dry years. Peak-flow frequency estimates for these stations probably are substantially biased and do not provide information representative of regional conditions. Also, only 3 of the 23 tributary stations with very small or relatively small drainage areas have peak-flow data for the wet climatic period of the 1990s. This limitation also contributes to greater uncertainty for peak-flow frequency estimates for smaller basins. In general, peak-flow frequency for tributary stations probably is well characterized for moderate and large drainage areas, but the uncertainty is relatively large for estimates for smaller drainage areas (less than about $100 \mathrm{mi}^{2}$ ).

Large peak flows occurred in relatively large areas of the James River Basin during 1969, 1984, 1993, 1995, and 1997 (table 8). Information concerning historical adjustments applied for individual large peak flows is presented in table 4 .

The very wet climatic conditions that occurred over large parts of eastern South Dakota during 1992-2001 (fig. 3) resulted in many large peak flows. Occurrence of this period in the systematic record of both short-term and intermediatelength stations can result in a substantial bias in peak-flow frequency estimates. In addition to the historical analyses used for many stations in the James River Basin (table 4), the mixed-station procedure was used for stations 06471350 , 06472000, 06474000, and 06474500 (map numbers 183, 187, 201, and 203) to adjust records appropriately.

Peak flows for station 06471000 (map number 180) are influenced by Mud Lake Dam and Sand Lake Dam on the James River in the Sand Lake National Wildlife Refuge and to a lesser degree by three relatively large reservoirs in North Dakota. Other main-stem stations downstream from 06471000 are not considered to be substantially influenced by these dams.

\section{Vermillion River}

The Vermillion River Basin is between the James and Big Sioux River Basins in southeastern South Dakota. Altitudes in the basin range from about 1,750 ft above NGVD 29 in headwater areas to about $1,150 \mathrm{ft}$ near the confluence with the Missouri River. The basin is largely within the glaciated James River Lowland physiographic division (fig. 2), which is characterized by poor drainage with numerous lakes and wetlands. The total drainage area of the Vermillion River is about 2,600 $\mathrm{mi}^{2}$ (table 6). The main stem of the Vermillion River begins at the confluence of the East and West Fork Vermillion Rivers.

Peak-flow frequency estimates are provided for 11 stations in the Vermillion River Basin (table 7). A substantial record-extension (table 3; 18 to 56 years) was accomplished for station 06479010 (map number 236) by using records for station 06479000 (map number 235). These two main-stem stations represent about 84 and 89 percent of the Vermillion River drainage area. In general, peak-flow frequency for the lower Vermillion River main stem probably is well characterized; however, the main stem in the middle part of the basin is poorly represented.

Nine stations are on tributaries to the Vermillion River (table 6) that are reasonably representative of a wide variety of drainage areas, given the relatively small drainage area of the basin. The periods of record for all short-term tributary stations are concentrated in the 1970s when dry climatic conditions predominated in eastern South Dakota (fig. 3). Record-extension procedures were investigated for the shortterm tributary stations, but correlations with long-term index stations were not suitable and record extensions were unsuccessful. One of the short-term stations (06478630; map number 228) has only 10 years of record, which are exclusively in very dry years. Peak-flow frequency estimates for this station probably are substantially biased and do not provide information representative of regional conditions. Further, of the eight tributary stations with very small or relatively small drainage areas, only one has peak-flow data after 1980; thus, there is little representation of 1984 (when general flooding occurred in the Vermillion River Basin) or the wet climatic period of the 1990s. In general, uncertainties are relatively large for peakflow frequency estimates for Vermillion River tributaries.

Large peak flows occurred in the Vermillion River Basin during 1969, 1984, 1993, 1997, and 2001 (table 8). These years are well represented in the systematic record for the long-term main-stem station (06479000), but generally are poorly represented in systematic records for tributary stations.

\section{Big Sioux River}

The Big Sioux River flows generally southerly, and the basin straddles much of the Minnesota/South Dakota border. Most of the basin is within the Coteau des Prairies physiographic division (fig. 2), which is characterized by poor drainage with numerous lakes and wetlands. Altitudes range 
from about 1,900 $\mathrm{ft}$ above NGVD 29 in the highest parts of the Coteau des Prairies to about $1,120 \mathrm{ft}$ near station 06485500 (map number 271). The total drainage area of the basin is about $8,850 \mathrm{mi}^{2}$, of which about $6,010 \mathrm{mi}^{2}$ is in South Dakota and about 1,500 $\mathrm{mi}^{2}$ does not contribute to surface-water runoff (table 6).

Peak-flow frequency estimates are provided for 35 stations in the Big Sioux River Basin (table 7). Nine stations are on the main stem, of which five are long-term stations with moderate to large drainage areas (table 6). Three of the main-stem stations have intermediate record lengths and have relatively small to large drainage areas. One of the main-stem stations is short term and has a relatively small drainage area. Records were extended for two main-stem stations (06479215 and 06479500; map numbers 239 and 244) by using other long-term main-stem stations as index stations (table 3). Stations on the main stem (map numbers 238, 239, 243, 244, 246, 258, 262, 264, and 270) represent about 1, 7, 11, 13, 23, 44, 51,59 , and 95 percent of the Big Sioux River drainage area. In general, peak-flow frequency for the Big Sioux River main stem is well characterized.

Regulation of the upper Big Sioux River occurs from two diversion structures along natural inlet/outlet channels to area lakes (table 1) between main-stem stations 06479438 and 06479500 (map numbers 243 and 244). Diversion capacities of the structures are relatively small and do not necessarily have large influence on most peak flows; however, peak flows can attenuate substantially in the reach between the two stations, primarily because of large natural storage capacity within the reach. These conditions result in decreased peak-flow characteristics between the two stations (table 7). Additional regulation results from a flood control diversion upstream from station 06482020 (map number 264); however, effects on peak-flow characteristics are considered relatively minor.

Twenty-six tributary stations in the Big Sioux River Basin (table 6) represent a wide variety of drainage areas; however, many of the periods of record are short. Record-extension procedures were investigated for all the short-term tributary stations; however, correlations were suitable for record extension (table 3) only for stations 06479910 and 06479928 (map numbers 254 and 255). Many of the short-term tributary stations have periods of record concentrated in the 1970s when dry climatic conditions predominated in eastern South Dakota (fig. 3). None of the tributary stations with very small drainage areas have peak-flow data after 1980. Thus, general flooding in the basin during 1984 and the wet climatic period of the 1990s are not represented; however, records for most of these stations include at least one large peak flow from 1962 or 1969. In summary, peak-flow frequency estimates may be biased for several individual short-term tributary stations; however, peak-flow frequency probably is reasonably well characterized for a wide variety of drainage areas.

Large peak flows occurred in relatively large areas of the Big Sioux River Basin during 1962, 1969, 1984, 1993, 1997, and 2001 (table 8). Occurrence of large peak flows from one or more of these years in the systematic record for a given station generally helps define the upper end of frequency curves. Information concerning historical adjustments applied for individual large peak flows is presented in table 4 .

\section{Summary}

Numerous users, including the South Dakota Department of Transportation, have continuing needs for peak-flow information for the design of highway infrastructure and many other purposes. This report documents results from a cooperative study between the South Dakota Department of Transportation and the U.S. Geological Survey to provide an update of statewide peak-flow frequency estimates.

Estimates of peak-flow magnitudes for 2-, 5-, 10-, 25-, 50-, 100-, 200-, and 500-year recurrence intervals are reported for 272 streamflow-gaging stations on the basis of data through water year 2001. This includes most gaging stations in South Dakota with 10 or more years of systematic peakflow records. Analyses are not reported for several stations with sufficient record, primarily because of proximity to other nearby stations for which frequency estimates were more reliable because of longer available periods of record.

Recommended procedures described in Bulletin 17B were used as primary guidelines for developing the peak-flow frequency estimates, and the computer program PEAKFQ developed by the U.S. Geological Survey was used to run the frequency analyses. Flood frequencies for all gaging stations initially were analyzed by using standard Bulletin 17B default procedures for fitting the log-Pearson III distribution. The resulting preliminary frequency curves were then plotted on a log-probability scale, and fits of the curves with systematic data were evaluated. In many cases, results of the default Bulletin $17 \mathrm{~B}$ analyses were determined to be satisfactory. In other cases, however, the results could be improved by using various alternative procedures for frequency analysis.

Alternative procedures for some stations included adjustments to skew coefficients or use of user-defined low-outlier criteria. Peak-flow records for many gaging stations are strongly influenced by low- or zero-flow values. This situation often results in a frequency curve that plots substantially above the systematic record data points at the upper end of the frequency curve. Adjustments to low-outlier criteria reduced the influence of very small peak flows and generally focused the analyses on the upper parts of the frequency curves (10- to 500-year recurrence intervals).

The most common alternative procedures involved several different methods to extend systematic records, which was done primarily to address biases for many gaging stations resulting from non-representative climatic conditions during several specific periods and to reduce inconsistencies among multiple gaging stations along common stream channels with different periods of record. In some cases, records for proximal gaging stations could be directly combined. In other 
cases, the two-station comparison procedure recommended in Bulletin 17B was used to adjust the mean and standard deviation of the logs of the systematic data for a target station on the basis of correlation with concurrent records from a nearby long-term index station. In some other cases, a "mixed-station procedure" that is based on the maintenance of variance type I (MOVE.1) straight-line fitting procedure was used to adjust the log-distributional parameters for a target station on the basis of correlation with one or more index stations for the purpose of fitting the log-Pearson III distribution. The mixed-station procedure can include multiple index stations, which in some cases allows incorporating additional important peak-flow events or periods that could not be achieved using a single index station. Also, the mixed-station procedure can be applied to cases in which an appropriate index station has a shorter record length than the target station.

Historical adjustment procedures recommended by Bulletin 17B also were used to extend systematic records for several gaging stations when documentation regarding historical peak flows could be substantiated. Historical adjustments were applied to peak-flow frequency analyses for 17 South Dakota gaging stations. Historical adjustments based on a period extending back to 1881 were made for 12 gaging stations in the James and Big Sioux River Basins, and shorterterm adjustments were made for additional stations. Large peak flows that occurred in 1969 and 1997 accounted for 13 of the 17 historical adjustments. Other years for which historical peak flows were used include 1957, 1962, 1992, and 2001.

A regional mixed-population analysis was developed to address complications associated with many high outliers for the Black Hills region. This analysis included definition of two populations of flood events. The population of flood events that composes the main body of peak flows for a given station is considered the "ordinary-peaks population," and the population of unusually large peak flows that plot substantially above the main body of peak flows on log-probability scale is considered the "high-outlier population." A regional "highoutlier population" was represented by using all independent peak flows identified as high outliers by the Grubbs-Beck outlier test for 36 stations in the Black Hills region with a minimum of 20 years of systematic record. The seven resulting peak flows were normalized by dividing by the contributing drainage area raised to the 0.6 power and were used to develop a regional probability distribution for the high-outlier population. For each gaging station, the site-specific highoutlier probability distribution was determined by rescaling the normalized, regional high-outlier probability distribution relative to the drainage area for the station. The final frequency distribution was then obtained by using joint-probability theory to combine the ordinary-peaks and high-outlier probability distributions.

Peak-flow characteristics are affected by a wide variety of hydrogeologic conditions in South Dakota. Land-surface altitudes range from about 1,000 ft above National Geodetic Vertical Datum of 1929 (NGVD 29) in the northeastern part of the State to more than 7,000 ft above NGVD 29 in some parts of the Black Hills region. The largest relief occurs in the Black Hills region, where relatively steep topography exists in many locations. Most of western South Dakota is well drained, and contributing drainage areas are equal to total drainage areas for most gaging stations. The primary exceptions are parts of the Little White River Basin, which is a major tributary to the White River.

In contrast, many parts of eastern South Dakota are relatively flat and poorly drained. Large volumes of depression storage can occur in the form of large or small lakes, large or small wetlands, or simply small undrained depressions in the middle of fields. A continental divide is located off the northeastern shoulder of the Coteau des Prairies that separates small headwater areas of the Red River of the North and the Minnesota River (which is tributary to the Mississippi River) that are in extreme northeastern South Dakota. Large areas within the James, Vermillion, and Big Sioux River Basins are considered noncontributing, and some areas can be variably contributing (noncontributing during low-storage conditions, but contributing when spill elevations of depressions are exceeded). Because of these conditions, unit peak flows (peak discharges per unit area) in many drainages in eastern South Dakota can be much smaller than for comparable drainage areas in other parts of the State.

Peak-flow characteristics have changed substantially for many rivers in South Dakota because of reservoir construction. The Missouri River has been highly regulated by a series of massive reservoirs constructed during the 1950s. Changes in peak-flow characteristics also have occurred from construction of thousands of relatively small reservoirs (locally referred to as "stock reservoirs") in South Dakota. Peak-flow potential probably has increased in parts of eastern South Dakota following draining of wetlands and other improvements to drainage.

Peak-flow characteristics for streams in the Black Hills region, which includes tributaries to the Cheyenne and Belle Fourche Rivers upstream from their confluence, can be distinctively influenced by unique hydrogeologic characteristics. Peak flows for basins in the limestone-headwater setting are distinctively suppressed relative to peak flows in basins in other hydrogeologic settings in the Black Hills region. For one example station (06408700), the maximum annual peak for 20 years of record is less than 4 times larger than the minimum annual peak. For many of the stations where drainage areas are primarily within the limestone-headwater setting, abrupt increases in slopes of the frequency curves result from application of the mixed-population analysis, which may result in overestimation of peak flows for larger recurrence intervals. Similar abrupt increases in slopes of the frequency curves can result from application of the mixed-population analysis for various other stations in other hydrogeologic settings that individually have relatively suppressed peak-flow characteristics, which can result from a variety of different hydrogeologic conditions. Thus, potential probably exists for overestimation of peak flows for larger recurrence intervals for other stations in other hydrogeologic settings. Within the loss-zone 
hydrogeologic setting, peak-flow characteristics generally are suppressed for small recurrence intervals, relative to peak-flow characteristics for upstream reaches. In general, peak-flow characteristics within the other hydrogeologic settings (that is, the crystalline-core, artesian-springs, and exterior settings) generally are less distinctive and subject to a larger variety of hydrogeologic influences, such as more variable geology, topography, and soil characteristics.

\section{References}

Advisory Committee on Water Information, 2007, Bulletin 17-B guidelines for determining flood frequencyfrequently asked questions, accessed April 30, 2007, at http://acwi.gov/hydrology/Frequency/B17bFAQ.html

Alila, Younes, and Mtiraoui, Ahmed, 2002, Implications of heterogeneous flood-frequency distributions on traditional stream-discharge prediction techniques: Hydrological Processes, v. 16, p. 1,065-1,084.

Alley, W.M., and Burns, A.W., 1983, Mixed station extension of monthly streamflow records: Journal of Hydraulic Engineering, American Society of Civil Engineers, v. 109, no. 10 , p. $1,272-1,284$.

Cary, L.E., and Parrett, Charles, 1996, Synthesis of natural flows at selected sites in the upper Missouri River Basin, Montana, 1928-89: U.S. Geological Survey WaterResources Investigations Report 95-4261, 109 p.

Crippen, J.R., and Bue, C.D., 1977, Maximum flood flows in the conterminous United States: U.S. Geological Survey Water-Supply Paper 1887, $52 \mathrm{p}$.

Culler, R.C., and Peterson, H.V., 1953, Effect of stock reservoirs in the Cheyenne River Basin above Angostura Dam: U.S. Geological Survey Circular 223, 33 p.

Driscoll, D.G., and Carter, J.M., 2001, Hydrologic conditions and budgets for the Black Hills of South Dakota, through water year 1998: U.S. Geological Survey Water-Resources Investigations Report 01-4226, 143 p., accessed May 30, 2007, at http://pubs.usgs.gov/wri/wri014226/.

Driscoll, D.G., Carter, J.M., and Ohlen, D.O., 2004, Hydrologic effects of the 1988 Galena fire, Black Hills area, South Dakota: U.S. Geological Survey Water-Resources Investigations Report 03-4323, 67 p., accessed April 30, 2008, at http://pubs.usgs.gov/wri/wri034323/.

Fenneman, N.M., 1946, Physical divisions of the United States: U.S. Geological Survey map prepared in cooperation with the Physiographic Commission, U.S. Geological Survey, scale 1:700,000 (reprinted 1964).
Flint, R.F., 1955, Pleistocene geology of eastern South Dakota: U.S. Geological Survey Professional Paper 262, 173 p.

Flynn, K.M., Kirby, W.H., and Hummel, P.R., 2006, Users manual for PeakFQ, annual flood frequency analysis using Bulletin 17B Guidelines: U.S. Geological Survey Techniques and Methods Report, book 4, chap. B4, 42 p.

Goddard, K.E., 1989, Composition, distribution, and hydrologic effects of contaminated sediments resulting from the discharge of gold milling wastes to Whitewood Creek at Lead and Deadwood, South Dakota: U.S. Geological Survey Water-Resources Investigations Report 87-4051, 76 p.

Grubbs, F.E., and Beck, Glenn, 1972, Extension of sample sizes and percentage points for significance tests of outlying observations: Technometrics, v. 14 , no. 4, p. 847-854.

Helsel, D.R., and Hirsch, R.M., 1992, Statistical methods in water resources: Amsterdam, Elsevier Science Publishers, $522 \mathrm{p}$.

Hortness, J.E., and Driscoll, D.G., 1998, Streamflow losses in the Black Hills of western South Dakota: U.S. Geological Survey Water-Resources Investigations Report 98-4116, 99 p., accessed May 30, 2007, at http://pubs.usgs.gov/wri/ wri984116/.

Jarrett, R.D., 1993, Flood elevation limits in the Rocky Mountains, in Kuo, C.Y., ed., Engineering hydrologyProceedings of the symposium sponsored by the Hydraulics Division of the American Society of Civil Engineers, San Francisco, California, July 25-30, 1993: New York, American Society of Civil Engineers, p. 180-185.

Jarrett, R.D., and Costa, J.R., 1988, Evaluation of the flood hydrology in the Colorado Front Range using streamflow records and paleohydrologic data for the Big Thompson River Basin: U.S. Geological Survey Water-Resources Investigations Report 87-4117, 37 p.

Martin, J.E., Sawyer, F.J., Fahrenbach, M.D., Tomhave, D.W., and Schulz, L.D., 2004, Geologic map of South Dakota: South Dakota Geological Survey, General Map 10, scale 1:500,000.

Matalas, N.C., and Jacobs, Barbara, 1964, A correlation procedure for augmenting hydrologic data: U.S. Geological Survey Professional Paper 434-E, 7 p.

Miller, L.D., and Driscoll, D.G., 1998, Streamflow characteristics for the Black Hills of South Dakota, through water year 1993: U.S. Geological Survey Water-Resources Investigations Report 97-4288, 322 p.

Murphy, P.J., 2001, Evaluation of mixed-population floodfrequency evaluation: Journal of Hydrologic Engineering, v. 6 , p. $62-70$. 
National Agricultural Statistics Service, 2007, Cropland data layer, accessed May 2, 2007, at http://www.nass.usda.gov/ Statistics_by_State/South_Dakota/Publications/Cropland_ Data_Layer/2007/statemap07.pdf

Sando, S.K., 1998, Techniques for estimating peak-flow magnitude and frequency relations for South Dakota streams: U.S. Geological Survey Water-Resources Investigations Report 98-4055, 48 p., accessed May 30, 2007, at http://pubs.usgs.gov/wri/wri98-4055/.

Schwarz, F.K., Hughes, L.A., Hansen, E.M., Petersen, M.S., and Kelly, D.B., 1975, The Black Hills-Rapid City Flood of June 9-10, 1972 - a description of the storm and flood: U.S. Geological Survey Professional Paper 877, 47 p., accessed May 30, 2007, at http://pubs.er.usgs.gov/usgspubs/pp/pp877

South Dakota State University, 2007, Monthly coop weather data: accessed May 2, 2007, at http://climate.sdstate.edu/ coop/monthly.asp

Strobel, M.L., Jarrell, G.J., Sawyer, J.F., Schleicher, J.R., and Fahrenbach, M.D., 1999, Distribution of hydrogeologic units in the Black Hills area, South Dakota: U.S. Geological Survey Hydrologic Investigations Atlas HA-743, 3 sheets, scale 1:100,000, accessed May 30,2007, at http://pubs.usgs. gov/ha/ha743/.

Thompson, R.F., 2007, Peak stages from backwater conditions at streamflow-gaging stations in and near South Dakota through water year 2001: U.S. Geological Survey Open-File Report 2006-1395, 55 p., accessed May 30, 2007, at http:// pubs.usgs.gov/of/2006/1395/.

U.S. Department of Agriculture, 2007, Conservation reserve program summary, accessed May 2, 2007, at $h t t p: / / w w w . f s a$. usda.gov/Internet/FSA_File/annual_consv_2007.pdf

U.S. Geological Survey, 2002, Water resources data for South Dakota, water year 2001: U.S. Geological Survey Water Data Report SD-01-1, 476 p.

U.S. Interagency Advisory Council on Water Data, 1982, Guidelines for determining flood flow frequency: Hydrology Subcommittee, Bulletin 17B, appendices 1-14, 28 p. 